\title{
Macroalgae as a sustainable aquafeed ingredient
}

by Wan, A.H.L., Davies, S.J., Soler-Vila, A., Fitzgerald, R. and Johnson, M.P.

Copyright, Publisher and Additional Information: This is the author accepted manuscript. The final published version (version of record) is available online via Wiley. This article may be used for non-commercial purposes in accordance with Wiley Terms and Conditions for Self-Archiving.

Please refer to any applicable terms of use of the publisher.

DOI: https://doi.org/10.1111/raq.12241

Harper Adams University

Wan, A.H.L., Davies, S.J., Soler-Vila, A., Fitzgerald, R. and Johnson, M.P. 2018. Macroalgae as a sustainable aquafeed ingredient. Reviews in Aquaculture. 


\section{Macroalgae as a sustainable aquafeed ingredient}

Alex H. L. Wan*A, Simon J Davies ${ }^{\mathrm{B}}$, Anna Soler-Vila ${ }^{\mathrm{C}}$, Richard Fitzgerald ${ }^{\mathrm{D}}$, and Mark P Johnson A

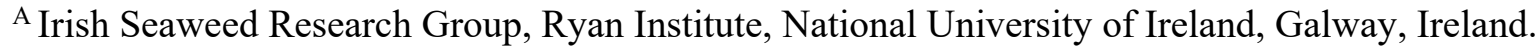

B Department of Animal Production, Welfare and Veterinary Science, Harper Adams University, Newport, Shropshire, TF10 8NB, UK.

${ }^{\mathrm{C}}$ Irish Seaweed Consultancy, Ryan Institute, National University of Ireland, Galway, Ireland.

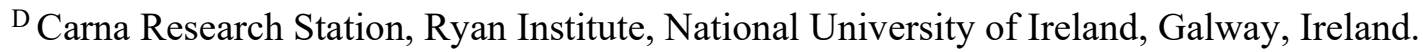

${ }^{*}$ Corresponding address: Alex H L Wan, Irish Seaweed Research Group, Ryan Institute, National University of Ireland, Galway, Ireland. Tel +353 9149 3964;

Contact email: alex.hing.wan@gmail.com 


\section{Abstract}

Macroalgae, commonly known as seaweed, offer a novel and added-value dietary ingredient in formulated diets for fish. Production of biomass can be achieved without reliance on expensive arable land, as seaweed may be collected from coastal regions or farmed. There are three taxonomic groups represented by the term 'macroalgae': Rhodophyta (red), Chlorophyta (green), and Phaeophyta (brown). Like terrestrial plants, nutritional content in macroalgae can vary greatly among species, genera, divisions, seasons and locations. Aside from their basic nutritional value, seaweeds contain a number of pigments, defensive and storage compounds, and secondary metabolites that could have beneficial effects on farmed fish. This review appraises the beneficial qualities of these macroalgae compounds and their potential for exploitation in commercial finfish feeds. The current knowledge of the effects of macroalgae inclusion in finfish diets is also addressed. From these $>50$ fish feeding studies that were analysed, enhancing trends in fish growth, physiology, stress resistance, immune system, and fillet muscle quality were reported. However, only a small fraction of algal species have so far been investigated as potential components in finfish diets, and furthermore, this review has identified a number of knowledge gaps that current research has yet to address. To conclude, an appraisal is made of the possible technologies employed to exploit seaweeds to an industrial level through stabilising the algal meal, enhancing the digestibility and functional food properties.

\section{Keywords}

Macroalgae, Seaweed, Aquaculture, Fish feedstuff, Functional ingredients. 


\section{Introduction}

Commercially formulated diets represent the largest proportion of the production costs in finfish aquaculture (Naylor et al., 2009). Furthermore, a continuing stagnation in the production of fish meal (FM) and fish oil (FO) from fisheries when coupled with a rising demand for finfish diets, has led to an overall increase in feed costs (Shepherd and Jackson, 2013). Consequently, both research institutions and feed manufacturers are seeking novel economically and environmentally sustainable sources of feed materials as replacements for FM and FO. Ultimately, for these feed ingredient replacement alternatives to be accepted, they must maintain growth, and overall health/survival and fillet quality of farmed fish, while meeting retailer and consumer expectations.

Replacement feed ingredients have a number of factors that affect their potential use. One potential feed ingredient, animal by-products, contains high levels of protein, lipid, vitamins and minerals. However, materials produced from waste streams of rendered terrestrial animals (e.g. offal and bone meal from bovine sources) are highly restricted in both the European Union (EC No 956/2008) and the United States (US FDA CPG Sec. 675.400). One recent exception is legislation that permits the inclusion of poultry by-product and feather meals (category 3 sources) into aquafeeds. Food source constraints arose after bovine spongiform encephalopathy (BSE) disease outbreaks in the European countries during the 1990s. Restrictions on diets based on farmed animal tissue, issues of source availability, and low-cost production, have seen plants as the principal alternative to FM and FO use in aquafeeds (Gatlin et al., 2007; Naylor et al., 2009). More recently, processing plant-based meals such as soybean, lupin, and various pulses, through applying exogenous enzymes, chemicals, and physical treatments, has allowed manufacturers to overcome the effects of anti-nutritional factors (ANF) and digestibility issues, which are commonly present in plant-derived ingredients. This has subsequently enabled elevated inclusion levels of plant meals in diets for less tolerant carnivorous finfish species, e.g. rainbow trout and Atlantic salmon (Le Boucher et al., 2012; Adeoye et al., 2016). In recent years, the world has seen a wave of governmental subsidies and venture capital 
investments into the renewable energy sector (FAO, 2009a). Aimed at reducing carbon dioxide emissions, farmers have taken advantage of these new incentives and moved from food to biofuel crop production (Rathmann, Szklo and Schaeffer, 2010; Harvey and Pilgrim, 2011). Furthermore, the non-renewable phosphate-rich minerals used for fertilising plant crops are gradually becoming scarce (Kraan, 2010). These factors, combined with an increasing global demand for food (FAO, 2009a), will probably see the price of plant meals and oils increase in the future to make it less attractive as an alternative to FM and FO in fish feeds (Rathmann, Szklo and Schaeffer, 2010). Consequently, questions have been raised by consumers on whether the use of animal and plant byproducts really is safe and sustainable for finfish aquaculture.

An alternative to plant meal is marine macroalgae; produced without the need for arable land, freshwater and the expensive fertilisers associated with terrestrial crop production. Macroalgae, or seaweed, encompasses algae that are multicellular, macroscopic and typically have a benthic lifestyle (Guiry, 2013). They are a diverse assemblage of algal species due to an early divergence in their divisions, which include Division Rhodophyta (red), Division Chlorophyta (green) and the Division Ochrophyta, Class Phaeophyta (brown). Marine macroalgae are found in the intertidal, subtidal coastal zones and estuarine habitats. Life in these habitats can be a challenge, and the organisms living there can experience a variety of physical stressors: temperature, light, salinity, desiccation and wave action, alongside biological pressures: predation, competition, parasitism and allelopathy (Paul, Nys and Steinberg, 2006; Akakabe and Kajiwara, 2008). Many of the secondary metabolites produced by the algae are seen as adaptive responses to these selective pressures. These metabolites include functional proteins (Cruces, Huovinen and Gómez, 2012), peptides (Harnedy and FitzGerald, 2011), mycosporine -like amino acids (Carreto and Carignan, 2011), carotenoids, phenolics (Dethier, Williams and Freeman, 2005), fatty acids (Alamsjah et al., 2007; Wang, Zhou and Tang, 2008), vitamins (Pinto et al., 2003), functional carbohydrates (Karsten et al., 1996) and other secondary metabolites (Oliveira et al., 2013; Svensson et al., 2013). Many of the compounds found in macroalgae are not yet fully understood. In addition to aiding macroalgal 
survival, some of these compounds have been found to have a beneficial effect on animals (e.g. pigs, broiler chicks, ruminants and finfish) when they are administered into feeds (Christaki et al., 2012; Rae et al., 2012; Ibañez and Cifuentes, 2013; Garcia-Vaquero and Hayes, 2015).

Indeed a comprehensive review of seaweeds as a viable protein source for monogastric livestock was undertaken by Angell et al., (2016) covering land animals and selected fish species, although these authors focussed principally on amino acid composition, protein concentration and development to optimise these nutrients in various seaweed products with further processing. However, the other important nutritional benefits of seaweeds were not highlighted in the latter review and important aspects not appreciated in the wider context of animal production and health.

With such promising attributes, seaweeds may fill more than just a nutritional role in aquafeeds: they may also promote fish health and fish welfare. This review will comprehensively examine the potential of both nutritional and functional components available in seaweeds that could benefit farmed fish. Emphasis will be given to the current knowledge of the effects of seaweeds has on fish growth performance, health, and muscle quality. An economic assessment and examination of the current legislative feed safety regulations are used to evaluate whether seaweed is currently viable for commercial fish diets. The present review will highlight current barriers that are hindering seaweeds from being exploited as a feed component in commercial diets, and the possible solutions to overcome these obstacles.

\section{Nutritional components of macroalgae for aquafeeds.}

Like terrestrial plants, the nutritional composition of macroalgae can be highly variable between divisions, genus and species (Table 1). Seasonality and geographic locality can also play an important role in influencing the nutritional composition found in the algal species. For example, crude protein levels in red macroalgae Palmaria palmata are much higher during the winter and spring months, compared to the summer and autumn seasons (Fleurence, 1999). While, Sargassum 
horneri and Cystoseira hakodatensis total lipid content have been found to be $15 \%$ higher during the winter months than any other season (Nomura et al., 2012).

\subsection{Moisture content}

One common attribute amongst all macroalgae is their high degree of water content, ranging from 64.9 to $94 \%$ (Table 1 ). In order to preserve this highly perishable biomass, drying offers a simplistic method for biomass preservation (Ratti, 2001). Practically, this can be a problematic process, which can affect the success of exploiting algae as a feed component on an industrial scale. Large amounts of fresh biomass are required for producing the same weight of dry material when compared to the drier terrestrial plants materials (Gatlin et al., 2007). In addition, facilities for processing the fresh biomass would have to be near to farms or collection sites to reduce transportation costs and degradation of the composition (Hart et al., 1976). The process of drying also represents one of the largest production costs, where fossil fuels are used to generate the necessary drying temperatures (Sagar and Suresh Kumar, 2010), and as such remains a large obstacle for macroalgae to be fully exploited in feeds for farmed finfish.

Raising seaweed drying temperatures can bring a reduction in: drying time, labour and other associated costs with prolonged drying time, however heat labile compounds (e.g. vitamins, proteins, unsaturated fatty acids, phenols and carotenoids) would consequently be vulnerable to degradation during the drying process (Niamnuy et al., 2008; Gupta, Cox and Abu-Ghannam, 2011). Macroalgae produced in subtropical and tropical countries have a lower drying cost because these areas can take advantage of the naturally higher air temperatures and consistent sunlight. Although, ionising UV radiation from solar drying can consequently lead to the degradation of labile compounds such as vitamins, phenols and carotenoids (Chan, Cheung and Ang, 1997; Arsi et al., 2005; Chan et al., 2009). Reviews by Abascal et al. (2005), Ratti (2001), and Sagar and Suresh Kumar, (2010), describe a number of other drying methods and their merits (e.g. cost, efficiency and preservation of heat sensitive compounds): ultrasonic, freeze drying, flash drying, microwave drying and pulse electric field, which could be applied to reducing algal water content. 


\subsection{Protein, peptides and amino acid composition}

Some of the highest protein content in seaweeds is found in the Rhodophyta division, these include Chondrus crispus, Gracilaria and Pyropia species (Table 1). Protein levels in Pyropia spp. can amount to $50 \%$ (DW, McHugh, 2003), and much of this can be attributed to the proteinic pigmentphycoerythrin (Harnedy and FitzGerald, 2011). Phycoerythrin can represent a large proportion of the protein fraction in many red algae species, and in some cases, seasonal variations in phycoerythrin ranged from 2 to $12 \mathrm{mg} \mathrm{g}^{-1}$ in Palmaria palmata (Martínez and Rico, 2002). These compounds are commercially exploited as food colourants and fluorescent components in bioassays, but these functional proteins can also have a range of bioactive properties that include anti-oxidant capacities, anti-inflammatory and hepatoprotective activities (Sekar and Chandramohan, 2007). In contrast, commercially important brown macroalgal species found in the Western hemisphere, such as kelps and Fucus spp. possess some of the lowest protein content in all three macroalgae groups, ranging from protein content of 5.3 to $19.8 \%$ (DW), Table 1 (Harnedy and FitzGerald, 2011).

The amino acid composition in many macroalgae can be considered relatively complete in terms of essential amino acids. Many algal species contain most of the essential and non-essential amino acids (Wahbeh, 1997; Ortiz et al., 2006; Gressler et al., 2010). Although some commercially important species like the red macroalgae Palmaria palmata lack the essential amino acid cysteine, P. palmata has high aspartic acid and glycine levels, with comparable levels of total essential amino acids relative to soy protein (Galland-Irmouli et al., 1999). Similarly, Himanthalia elongata (sea spaghetti), Undaria pinnatifida (wakame), and Pyropia umbilicalis can have low amounts of methionine, isoleucine and phenylalanine (Cofrades et al., 2010). Proteins and peptides derived from seaweeds have shown an extensive range of bioactive properties that could be applied to pharmaceutical and nutraceutical products (Harnedy and FitzGerald, 2011). Much of these activities can be developed by degrading seaweed proteins using hydrolysis. An example of this is the use of 
enzymatic hydrolysis on Pyropia columbina to produce hydrolysates that have significant amounts of biological activity (e.g. antihypertensive, antioxidative and immunosuppressive activity) when compared to the untreated seaweed (Cian, Martínez-Augustin and Drago, 2012).

Algal cell walls are formed from structural carbohydrates and present a barrier to the digestion of cytoplasmic proteins (Bobin-Dubigeon et al., 1997). Physical treatments, fermentation and enzyme treatments have all been shown to improve seaweed protein availability. For example, Palmaria palmata has low protein digestibility when it is untreated, however, after a combination of physical treatment (freeze-drying and $110^{\circ} \mathrm{C}$ exposure) and fermenting with Trichoderma pseudokoningii microbe, in vitro protein digestibility increased by nearly four-fold (Marrion et al., 2003).

\subsection{Lipids}

Lipids are high energy-dense compounds, more so than proteins and carbohydrates, or any other nutritional component found in food. Aquafeeds are often formulated with high lipid content, and the resulting benefits can be a protein sparing capability, improvements in feed conversion efficiency, and enhanced growth performance for most fish species of commercial significance (Guillaume et al., 2001). For the consumer, polyunsaturated fatty acids (PUFA), in particular, long chain highly unsaturated fatty acids (HUFA) with a $\omega-3$ configuration are regarded as a 'functional food' component. In farmed Atlantic salmon, an increase in dietary $\omega$-3 HUFAs has been shown to have beneficial effects in producing a leaner fish (reduced fat deposition) through the increase in mitochondrial $\beta$-oxidation activity (Todorcević et al., 2009). While in humans, the consumption of foods that are rich in $\omega-3$ HUFAs can have a beneficial effect as an anti-inflammatory agent, improving cardiac health, and brain development and function (Ruxton et al., 2004). Although in recent years, diets used in farmed finfish have moved from marine to plant-based ingredients that include oils; this has consequently lowered the $\omega-3$ content. Some of the highest lipid content can be found in the brown algal group. Gosch et al. (2012) observed the brown algae Spatoglossum macrodontum had over $10 \%$ of total lipids. From that, $50 \%$ of the lipid extracted was free fatty acids. Similarly, two other brown alga species from the same order (Dictyotales): Dictyota 
acutiloba and Dictyota sandvicensis, were reported to have a total lipid content of $16.1 \%$ and 20.2 $\%$ (DW), respectively (McDermid and Stuercke, 2003). The extensive review carried out by Miyashita et al. (2013) found temperate brown algae species produced more lipids than those growing in tropical seas. However as shown in Table 1, many of the commercially important seaweeds can be limited in their lipid content. While, macroalgae may not possess as high lipid content as microalgae and terrestrial plants (e.g. Schizochytrium, sunflower, linseed and rapeseed), there may be compensation in terms of lipid quality and therefore augment the overall feed fatty acid composition. Many of the macroalgae species possess a high proportion of HUFA and polyunsaturated fatty acids (PUFA), in particular $\omega-3$ fatty acids, such as eicosapentaenoic acid (EPA, 20:5n-3), stearidonic acid (SDA, 18:4n-3), $\alpha$-linolenic acid (ALA, 18:3n-3) and arachidonic acid (ARA, 20:4n-6) (Miyashita, Mikami and Hosokawa, 2013).

By modifying different elements of the environmental conditions, it is possible to enhance both total lipid content and the fatty acid profile. For example, exposing the Grateloupia sparsa to a combination of low light intensity and high salinity resulted in an enhancement of lipid content and unsaturated fatty acid composition, e.g. two-fold increase in total $\omega-3$ fatty acid composition compared other treatments (Floreto and Teshima, 1998). More importantly, the authors observed that exposure to high irradiance levels had beneficially increased the $\omega-3$ fatty acids, particularly EPA, ARA and SDA fatty acids. Likewise, exposure of the red algae Tichocarpus crinitus to high photosynthetically active radiation led to a 1.5 fold increase in storage lipids, and significantly higher levels in 18:1 and 16:1 monounsaturated fatty acid (Khotimchenko and Yakovleva, 2005).

\subsection{Carbohydrates}

Simple sugars and polysaccharides are principal chemical energy stores in seaweeds as well as providing structural support for cells (Percival, 1979). These principal compounds also make up one of the largest fractions of the algae composition, with carbohydrate concentrations ranging from 1.8 
to $66 \%$ (dry weight, Table 1). Kelp species (Phaeophyceae) in particular possess some of the highest carbohydrate levels in any macroalgal group, ranging from 50-60 \% (DW, Kraan, 2010). Polysaccharides such as cellulose, hemicellulose and lignin can be commonly found in seaweeds; however as shown in Table 2, distinct polysaccharides can be found within each division, class, order, and even genus (Jiménez-Escrig and Sánchez-Muniz, 2000). Several of the algal polysaccharides have physical-chemical properties that allow the formation of gels, colloids and emulsions (Table 2). Known as phycocolloids, these polysaccharides (e.g. agar, alginates, carrageenan) have been the principal extracts from seaweeds for use in foods, cosmetics, pharmaceuticals and industrial products (Campo et al., 2009; Holdt and Kraan, 2011).

The presence of algal polysaccharides in formulated fish diets can have a number of influences on the overall quality. As these compounds act as emulsifiers and colloids, it would invariably change feed stability, such as the rate of nutrient leaching when exposed to the water column. Diet viscosity and texture will be modified, especially when diets with the presence of phycolloids are subjected to the high temperatures and pressures associated with the feed extrusion process (Borgogna, Bellich and Cesàro, 2011). Very little is known about how this would impact the diet quality and acceptability when fed to finfish. What is currently known is that when Ulva or carrageenan supplemented diets were subjected to water immersion, algal diets had maintained lower mass loss compared to non-algal inclusion (Hashim and Saat, 1992). Contrary to this, carrageenan used as the binder component in white sturgeon (Acipenser transmontanus) larvae diets did not increase feed stability during prolonged water exposure (Gawlicka et al., 1996). Polysaccharides with the ability to form emulsions and gels may also have applications in microencapsulation technology for aquaculture, where algal polysaccharides have been used for effective oral administration of vaccines and pharmaceutical drugs (Borgogna, Bellich and Cesàro, 2011). 
Beyond uses for gelling and stabilising, seaweed polysaccharides also have the potential of eliciting favourable physiological responses in animals and humans. For example, ulvan, has been demonstrated to produce promising results as an antibacterial, and antiviral agent against influenza and herpes simplex virus (Lahaye and Robic, 2007). Compounds acting as immune-stimulants to either innate or/and adaptive immune system has been of much interest to finfish aquaculture (Magnadóttir, 2006). Dietary inclusion of sodium alginate or $\kappa$-carrageenan in brown-marbled grouper (Epinephelus fuscoguttatushas) demonstrated that these compounds had the capacity to enhance the fish innate immunity (leukocyte count, respiratory burst, phagocytic activity and phagocytic index), and increase survival rate when challenged against the pathogen Vibrio alginolyticus (Cheng, Chen and Chen, 2008). The use of Ulva rigida polysaccharide extracts stimulated turbot (Psetta maxima) respiratory burst activity (Castro et al., 2006). Both studies speculated that the observed enhanced immunity was due to seaweed polysaccharides or their breakdown products acting as ligands for the leukocyte cell receptors. Another set of compounds that have drawn increasing interest in the aquaculture industry is the $\beta$-glucan sugar monomers, with a number of studies showing it may act to stimulate the fish immune system (Meena et al., 2013). Although there have been few studies reporting on the use of algal glucan in farmed fish. Sulphated laminarin (composed of $\beta(1,3)$-D-glucan) from Laminaria hyperborea, was shown to have the capacity to enhance components of the immune system (head kidney macrophage superoxide anion production and acid phosphatase activity) in Atlantic salmon (Salmo salar, Dalmo and Seljelid, 1995). $\beta$-1,3/1,6-glucan monomer derived from Laminaria digitata fed to gilthead seabream (Sparus aurata), also produced favourable immune responses (Guzmán-Villanueva et al., 2014). When $\beta$-glucan was administered in conjugation with an isolated probiotic strain of Shewanella putrefaciens, the combined treatment had even higher efficacy in enhancing the phagocytic ability and capacity in seabream.

The use of prebiotics in finfish aquaculture has drawn much interest in recent years as an alternative to the growing problems associated with prophylactic antimicrobial treatments, e.g. antibiotics and 
pharmaceutical drugs (Cabello, 2006). With reference to indigestible compounds e.g.

oligosaccharides and polysaccharides, these may benefit gut health by selectively stimulating the growth of beneficial microbes or microbial communities (Ringo et al., 2010). A review by O'Sullivan et al. (2010) discusses the potential of carbohydrates in seaweed to have potential prebiotic properties. For example, low molecular weight oligosaccharides derived from degraded agar (Gelidium sesquipidale) can enhance in vitro bifidobacterial populations (Ramnani et al., 2012). Long-chained glucans such as those found in laminarin have shown the capacity to stimulate probiotic bacteria (e.g. Lactobacillus spp. and Lactobacillus spp.) in farmed pigs (Lam and ChiKeung Cheung, 2013). Several other farmed animal studies have reported the beneficial effects of dietary seaweed inclusion on the gut microbial community (Goñi et al., 2001; Dierick, Ovyn and De Smet, 2009; Ishihara et al., 2010), although currently there are no known studies describing the effects of dietary seaweeds have on gut microflora in farmed finfish. While certain carbohydrate fractions can have functional effects, other complex carbohydrates (e.g. non starch polysaccharides NSP's) in fish feed, and in particular, insoluble fibres, can have detrimental influences on nutrient absorption, growth performance and gut morphology (Francis, Makkar and Becker, 2001). This is particularly significant in many of the farmed carnivorous fish (e.g. trout, salmon and sea bass and sea bream), where carbohydrates are often poorly digested and metabolised as an energy source (Kamalam, Medale and Panserat, 2015).

\subsection{Phenolics}

Phenolics, also known as polyphenols, are multi- benzenoid ring compounds that have been widely described in plant meals used in aquafeeds, including cottonseed, canola and rapeseed (Francis, Makkar and Becker, 2001; Drew, Borgeson and Thiessen, 2007). These phytocompounds are known to have a range of biological effects; some have therapeutic functions, while others are known for their toxicological effect and/or anti-nutritional properties. For example, the phenolic group known as gossypol are commonly found in cottonseed meal (Gossypium genus). Incorporating untreated cottonseed meals into fish feeds has exhibited a range of detrimental 
effects, including slow growth rates, organ deformities and sequestering of the amino acid methionine through gossypol-protein complexes (Francis, Makkar and Becker, 2001). The effects are so significant that the European Union legislation (Directive 2002/32/EC) has set maximum levels of gossypol in compound diets for farm animals and fish. In comparison, there are no national or international legislations or recommendations, restricting phenolics in seaweed meal for use in animal feeds. This reflects knowledge gaps in how such macroalgae phenolics affect cultured fish. In a dietary investigation on Wistar rats, extracts of phlorotannin compounds from Ascophyllum nodosum and Fucus vesiculosus caused a significant decrease in carbohydrate assimilation through depressed $\alpha$-amylase and $\alpha$-glucosidase activity (Roy et al., 2011). While experiments on phenolic extracts from Ecklonia radiata, reduced lipid peroxidation when added into FOs (Kindleysides, Quek and Miller, 2012). These findings suggest possible treatments for obesity and diabetes in humans if used as a functional food component, however, some phenolic compounds can also represent an element that could be unfavourable to farmed fish (Francis, Makkar and Becker, 2001). This was evident from decreased voluntary feed intake in rock prickleback (Xiphister mucosus) fish fed with $>10 \mathrm{kDa}$ phlorotannins, while $<5 \mathrm{kDa}$ had no effect (Boettcher and Targett, 1993). Contrary to these reported negative effects, some phlorotannins have demonstrated beneficial effects on photoprotection (Cha et al., 2012), and in reducing oxidative stress (Kang et al., 2013). Furthermore, there has been great interest in the application of algal phenolic compounds as a therapeutic treatment and for enhancing shelf-life stability in foods (Gupta and Abu-Ghannam, 2011; Liu, Hansen and Lin, 2011).

Bromophenols, like many other groups of algal phenolic compounds, can have antioxidant, anticancer and antibacterial activities (Xu et al., 2010). Another noteworthy quality which could be exploited in aquaculture is that low molecular weight bromophenols can enhance 'sea-like' flavours (Liu, Hansen and Lin, 2011). A feeding study on silver seabream (Sparus sarba) found that it was possible to enhance muscle fillet flavour when fish were fed with diets which included Sargassum siliquastrum and Padina arborescens (Ma et al., 2005). Accumulation of bromophenols in the fish 
muscle was most effective in the $S$. siliquastrum inclusion diet, where levels were reported as two times higher compared to fish fed a control diet with no algal inclusion. In relation to taste, freshwater finfish can often have a muddy and earth-like taste which results in a lowered market value compared to marine finfish (Tucker, 2000). The causative agent for this unpalatable taste is geosmin and 2-methylisoborneol, which accumulate in lipid rich tissues in the fish. These volatile organic compounds are excreted by microorganisms such bacteria, microalgae and cyanobacteria that are found inhabiting freshwater environments, and they are readily absorbed by finfish (Yarnpakdee et al., 2014).

\subsection{Carotenoids and vitamins}

Carotenoids play fundamental roles in seaweeds in photo-protection and photosynthesis. The distinct range of pigments synthesised by each algal group has traditionally been used as a means of algal classification. The structure of carotenoids consists of a polyisoprenoid backbone, with an aromatic ring at one or both ends of the hydrocarbon chain. The $\pi$ electrons found in the double bonds along the hydrocarbon chain are highly delocalised. Subsequently, small energy is required to change their transition state which gives rise to the compounds unique colouration of yellow, orange and red; or the visible light wavelength 400-500nm (Britton, Liaaen-Jensen and Pfander, 2008).

With over 750 known carotenoids being identified, this large family of lipophilic compounds can be chemically separated into two distinct groups: carotenes (e.g. $\beta$-carotene and lycopene) and xanthophylls (e.g. lutein, astaxanthin and canthaxanthin) (Maoka, 2011). The distinction between the two is that the latter possesses oxygen side group(s), while the former does not. Carotenoids possess a range of functional properties that include being a strong antioxidant, a free-radical scavenger, and singlet oxygen quencher (Sarada, Baskaran and Ravishankar, 2009; Ambati et al., 2014). In addition, several carotenoids have demonstrated anti-inflammatory activity, anti-tumour 
activity and have been shown to improve the immune system (Christaki et al., 2012). Several carotenoids ( $\alpha$-carotene, $\beta$-carotene and $\beta$-crytoxanthin) are also known as precursors to the nutritionally important vitamin A and retinol (Britton et al., 2008). The addition of xanthophylls such as astaxanthin and lutein into animal feeds have been extensively applied to poultry and salmonid farming as a means to increase yolk and flesh pigmentation. In aquafeeds, there has been a long history of using synthetic carotenoids (astaxanthin and canthaxanthin), however, natural alternatives derived from sources such as Phaffia and Haematococcus (Breithaupt, 2007) are now being used by the industry (e.g. for organic fish farming).

Seaweeds are a source of water-soluble vitamin B 2 (riboflavin), B 12 (cobalamin) and C (ascorbic acid) and lipid soluble vitamin $\mathrm{E}(\alpha, \beta, \gamma, \delta$ tocopherol, and $\alpha, \beta, \gamma, \delta$ tocotrienol). Acting as coenzymes and forming complexes, the family of vitamin B compounds are essential for normal cell metabolic function. Deficiency in the vitamins can result in an array of physiological symptoms in fish. Depending on the specific deficiency, they can range from degenerative organs, haemorrhages, cataracts, poor growth and feed conversion ratio etc (Beyer et al., 2002). Dagnelie, Staveren, Berg (1991) observed macroalgae (nori) vitamin B 12 was readily absorbed in children as shown by increase in plasma $\mathrm{B}_{12}$ concentration. However, the increase did not yield therapeutic effects such as improvements in mean corpuscular volume. The authors theorised that the vitamin cobalaminin algae were either pseudo-forms or bound to other compounds (e.g. polysaccharides) that make the vitamin bio-unavailable to humans. Little is known on whether this also applies to farmed finfish, and how these ligands can affect other sources of dietary cobalamin.

Both vitamin $\mathrm{C}$ and $\mathrm{E}$ play roles in promoting immunological responses, but also have antioxidant activity, particularly vitamin E (Gatlin 2002). Vitamin E from seaweeds can be especially important in aquaculture feeds, as it can serve as an internal antioxidant preventing the macroalgal PUFA from becoming oxidised. Variations in vitamin content between species are common in seaweeds, 
evident in one study that found predominately the $\gamma$-tocotrienol form of vitamin E in Durvillaea antarctica and Ulva lactuca, but the former had higher amounts of the more potent antioxidant, $\alpha$ tocopherol (Ortiz et al., 2006). Holdt and Kraan (2011) found that, in general, Ulva species had high levels of total vitamin E compared to Ascophyllum, Fucus and Laminaria spp.

\subsection{Macro and trace elements}

Macroalgae have the ability to accumulate high concentrations of macro (e.g. sodium, magnesium, phosphorous, calcium and potassium ) and trace elements (e.g. manganese, iron, cobalt, nickel, zinc and selenium) from their surrounding environment (Dawczynski et al., 2007). The rate of accumulation can be influenced by growth rate, the age of the alga and abiotic factors, such as temperature, nutrient availability, light intensity, and salinity (Malea, Haritonidis and Kevrekidis, 1995; Mamboya et al., 2009). Reviews carried out by Ruperez (2002) and Holdt and Kraan (2011) have described the potential of macroalgae as a mineral additive to animal formulated diets. In one particular study, it was noted that commercially available red and brown macroalgae contained high levels of iron, manganese, zinc, copper, selenium, and iodine than green algal species (Dawczynski et al., 2007).

Many of the macro and trace elements are essential nutritional metals for maintaining normal cellular metabolic function (Lall, 2003). However, if the concentration of an element exceeds dietary requirements, then it is possible that the element can induce toxicological effects on the organism, e.g. copper, and selenium (Watanabe, Kiron and Satoh, 1997). Some elements can be referred as potentially toxic elements (e.g. vanadium, arsenic, chromium, arsenic, silver, cadmium, tin, mercury and lead), where toxicological effects occur at lower concentrations. For instance, dietary exposure of copper $>35 \mathrm{mg} \mathrm{kg}^{-1}$ in Atlantic salmon (Salmo salar) showed reduced growth, increased intestinal cell proliferation, and apoptosis rates, but when compared to the addition of dietary cadmium, these effects were observed at a lower concentration of $5 \mathrm{mg} \mathrm{kg}^{-1}$ (Lundebye et 
al., 1999). Anthropogenic inputs from agriculture, aquaculture, domestic and industrial activities can very often lead to elevated levels of potentially toxic elements in the aquatic system, which could result in high metal content accumulated in the local seaweed population (Davis, Volesky and Mucci, 2003; Ryan, McLoughlin and O’Donovan, 2012). Furthermore, the nutrient enrichment (e.g. nitrogen and phosphorous) from anthropogenic inputs can also enhance metal uptake rate in macroalgae. For example, Ulva fasciata exposed to elevated nitrate levels can increase cadmium accumulation rate, while the increase in phosphate concentrations enhanced chromium accumulation (Lee and Wang, 2001).

A seaweed's level of affinity to any particular element can be division, genus, or species specific (Philips, 1990). In some algal species, high levels of potentially toxic metals may be found naturally. Hijiki, for example, (Phaeophyceae- Sargassum fusiforme) is commonly sold in the United Kingdom as a human food product, yet contained arsenic levels that were 30-50 fold higher (67-98 $\left.\mathrm{mg} \mathrm{kg}^{-1}\right)$ than the daily recommended allowance in adults (Rose et al., 2007). Besada et al. (2009) had expressed similar concerns in relation to commercially available seaweeds: substantial levels of cadmium (French regulatory levels, Cd $0.5 \mathrm{mg} \mathrm{kg}^{-1}$ ) and arsenic (As $3.0 \mathrm{mg} \mathrm{kg}^{-1}$ ) were measured in species that included Eisenia bicyclis $\left(\mathrm{Cd} 0.8 \& 34.1 \mathrm{mg} \mathrm{kg}^{-1}\right)$, Hizikia fusiforme $(\mathrm{Cd}$ $2.5 \&$ As $\left.147.00 \mathrm{mg} \mathrm{kg}^{-1}\right)$, Chondrus crispus (Cd $\left.0.7 \& 5.50 \mathrm{mg} \mathrm{kg}^{-1}\right)$ and Undaria pinnatifida (Cd $\left.4.8 \& 76.90 \mathrm{mg} \mathrm{kg}^{-1}\right)$. Safe dietary thresholds for elements like arsenic usually refer to the inorganic fraction of the element. Many of the elements present in seaweeds can be found in their organometallic forms, e.g. methyl, sugars and even bound to amino acids (Yan et al., 2004; Coelho et al., 2005; Rose et al., 2007). In seaweeds, arsenic is predominately found as organic species, where it is bound to ribose forming arsenosugars. Studies have shown that these arsenosugars exhibit lesser acute toxicological effects than inorganic arsenic species (Andrewes et al., 2004; Besada et al., 2009). Elements can also interact with carbohydrates, which chelate the metals and modify the overall toxicity and bioavailability (Gyurcsik and Nagy, 2000). Seaweeds are inherently rich in carbohydrates and possess unique polysaccharides (e.g. ulvan, alginate, agar, and laminarin) 
that are used for selective absorption of cations, and cell wall and internal matrices formation (Kim, 2014). The estimation of metal bioavailability in seaweeds using the dialysability method found positive correlations between metal bioavailability $(\mathrm{Cr}, \mathrm{Co}, \mathrm{Ni}, \mathrm{As}$ and $\mathrm{Se})$ and carbohydrate content (Moreda-Piñeiro et al., 2012; García-Sartal et al., 2013). However, the same study found that there were negative correlations between metal bioavailability and protein concentrations.

Overall, metals found in seaweeds are perceived to have a limited toxic effect on the consumer and farmed animals, although further research on speciation and metabolic pathways is needed (e.g., Taylor et al., 2017).

\section{Macroalgae in fish diets}

\subsection{Fish growth performance}

One of the earliest reported studies on macroalgae inclusion in formulated finfish diets was by Nakagawa et al. (1984), where dried and milled Ulva pertusa meal was tested as a FM replacement in black sea bream (Acanthopagrus schlegeli) diet. Their findings had shown that the addition of 10 $\%$ algae into formulated diets produced elevated protein efficiency, while other measured growth

performance indicators remained unchanged. Since then, a number of studies have been performed on other fish species and tested a range of other seaweed species. Nevertheless, when compared to the number of macroalgae species known to science, only a limited number of species has been fully evaluated on fish mainly under controlled laboratory conditions. Much of the focus has been on incremental inclusions in balanced diet formulations either at the expense of some of the fish and soya bean meals with levels ranging from 5-30 \% with many reporting an optimum level of around $15 \%$ before growth is impaired (Table 3 ). This is particularly relevant to carnivorous fish species, where the response to plant feed material supplementation has been lower fish growth performance (Oliva-Teles, Enes and Peres, 2015). 
Many of the feeding studies have been primarily focused on key carnivorous fish species, such as

trout, salmon, seabream, seabass, and flounder of high commercial value. Furthermore, many of the reported studies have centred on several genera of macroalgae, which include the Ulva, Gracilaria, and Porphyra species. This can be explained by the ease of collection from the wild for the feeding experiment, and that they hold commercial value in the food and phycocolloid industries. Although, arguably there are limited reports of brown macroalgae species, which are important in food and phycocolloid production.

In some studies, it was observed that the inclusion of macroalgae could enhance some growth performance parameters. This was the case in European seabass (Dicentrarchus labrax) fry after being fed with $5 \%$ Pterocladia capillacea inclusion diets, with an increase in body weight, and weight gain (Wassef, El-Sayed and Sakr, 2013). Similarly, Pyropia (Porphyra) yezoensis spheroplasts meal inclusion (5\%) in red seabream (Pagrus major) diet resulted in increase of fish final weight, weight gain, percentage growth rate, specific growth rate (SGR), protein efficiency ratio (PER), and a decrease in FCR (Kalla et al., 2008). In principal, these studies have shown that there is considerable scope for inclusion if the protein level in the seaweed is sufficiently high, and with a balanced amino acid profile comparable to the main plant protein ingredients (Angell et al., 2016).

\subsection{Macroalgae digestibility and palatability.}

Previous feeding experiments have shown that there are discrepancies in the digestibility of different macroalgae species when formulated into finished feeds. Much of this could be attributed to the levels and types of complex polysaccharides found in the seaweeds, where these compounds act as barriers and chelators (Gyurcsik and Nagy, 2000; Marrion et al., 2003). The biology of the farmed fish can also contribute to the degree of digestibility in seaweeds, e.g. nutritional group, natural feeding strategies, exercise, and genotype (Krogdahl, Hemre and Mommsen, 2005; 
Kamalam, Medale and Panserat, 2015). Natural feeding strategies are particularly relevant to farmed carnivorous fish species (e.g. trout and salmon). While it has been shown that simple carbohydrates are digested and absorbed through the gut wall, it may not be the case for more complex carbohydrates, e.g. cellulose, xylan, and phycocolloids (Wilson, 1994). This may be due to a lack or low presence of carbohydrate degrading enzymes (Hidalgo, Urea and Sanz, 1999), and will have consequences for the farmed fish to fully utilise all the nutrients within the seaweed component of the diet. Moreover, if carnivorous species were able to digest and absorb the carbohydrates, much of this will subsequently be stored in the fish tissues (e.g. liver and muscle) as lipids are preferentially utilised as a source of metabolic energy (Kamalam, Medale and Panserat, 2015). However, there is limited evidence that herbivorous and omnivorous fish were more effective at digesting and utilising seaweeds in their diet. For example, feeding trials carried out on the primarily herbivorous fish Nile tilapia (Oreochromis niloticus) showed that dietary inclusion of seaweeds had little improvement on nutrient utilisation and growth performance (Table 3).

As described earlier in the review (Section 2.4 and Table 2), each macroalgal group produces their own unique range of polysaccharides, which can subsequently affect the efficiency of nutrient assimilation in the fish gut (Sinha et al., 2011). As such, modifications in the fish's nutrient utilisation and physiological response (e.g. growth, health, and muscle quality) may improve with one macroalgae species but not another due to the variations in polysaccharides content and composition.

While carbohydrates can affect digestibility, other compounds, namely phenolic compounds, existing in seaweeds could influence overall palatability of the finished product (Steinberg, 1989). Several studies have described that increased seaweed inclusion (Ulva spp., Eucheuma denticulatum \& Gracilaria lemaneiformis ) has no apparent effect on the overall palatability of the experimental diet (Marinho et al., 2013; Xuan et al., 2013; Ragaza et al., 2015). However, the 
increased addition of Ulva lactuca in African catfish (Clarias gariepinus) diet showed a decline in feed palatability at inclusion levels of $20 \%$ (Abdel-warith, Younis and Al-asgah, 2015).

\subsection{Physiological and health responses.}

Seaweeds in aquafeeds can go beyond offering the essential nutrients typically found in traditional feed ingredients, such as fishmeal and soybean meal. The complex matrix of bioactive compounds found in seaweeds can elicit responses beyond gross growth performance enhancements in fish. The potential of these compounds can cause physiological modifications that might either have a beneficial or impairing effect on the fish. In feeding Eucheuma denticulatum supplemented diet (up to $9 \%$ ) to Japanese flounder, P. olivaceus, the authors observed a significant decrease in both total cholesterol and triglyceride levels when algae inclusion level was increased (Ragaza et al., 2013). Likewise, dietary inclusion of Gracilaria pulvinata up to $9 \%$ level in barramundi (Lates calcarifer) feeds also decreased serum triglycerides and cholesterol (Morshedi et al., 2017). The authors suggest that the presence of high soluble fibre content or $n-3$ fatty acids could have attributed to these changes. For salmonid species, it has been reported that the inclusion of $15 \%$ Palmaria palmata in Atlantic salmon (Salmo salar) diet had enhanced liver function through a decrease in serum alanine transaminase activity (Wan et al., 2016).

A topical issue with fish farming is whether diets could have functional properties to naturally improve fish immune response to diseases. In the case of seaweed being fed to fish, an enhanced immunological response has been observed in olive flounder (Paralichthys olivaceus, (Pham et al., 2006; Choi, Lee and Nam, 2015), red seabream (Pagrus major, Gakkaishi et al., 1987), Nile tilapia (O. mykiss, (Valente, Araújo, et al., 2015), and white-spotted spinefoot (Siganus canaliculatus, Xu et al., 2011). These immunological responses are varied from increased lysozyme activity to alternative complement pathway activity. As discussed earlier, it is probable that the presence of complex carbohydrates (e.g. alginates and agar) in seaweed confer immunostimulation. The use of 
carbohydrates and crude extracts derived from seaweeds in fish diets confirm this as past studies have observed positive stimulation of fish immune parameters. For instance, alginate extracted from the brown alga Ascophyllum nodosum added at a $5 \%$ inclusion level to a wet diet had enhanced lysozyme activity in Atlantic salmon (S. salar). For Basa fish (Pangasius bocourti), dietary supplementation of low-molecular weight agar $(0.2 \%)$ had invoked an increase in alternative complement pathway activity by three-fold and over two-fold post challenge (Aeromonas hydrophila) survival rate (Van Doan, Doolgindachbaporn and Suksri, 2014). Recent studies had also shown that even the use of crude extracts from seaweeds attained immunostimulatory effects in fish. For dietary inclusion of fucoidan-rich extracts from Sargassum wightii enhanced a variety of immunological parameters (e.g. respiratory burst activity, lysozyme activity, phagocytic activity, and total leukocyte count) in Pangasianodon hypophthalmus (Prabu et al., 2016). Similarly, in vitro exposure of sole (Solea senegalensis) phagocytes to ethanolic extracts of Hydropuntia cornea increased superoxide anion production by $>50 \%$ (Díaz-Rosales et al., 2007).

The presence of macroalgae in the fish diet can also have significant changes in the gut. Morphological examinations carried out on Nile tilapia (O. niloticus) showed there was a reduction of both proximal intestinal diameter and villi length (Silva et al., 2014). This was particularly evident after being fed for 84 days on $10 \%$ inclusion diet. The significant decrease of $35 \%$ in intestine diameter and $46 \%$ villi length had correlated with an observed lowering in growth performance. This suggests that inclusion of macroalgae in fish feeds should be treated cautiously to prevent reduction of overall feed digestibility.

\subsection{Modifications on body and muscle quality}

Feeding trials which examined the effects that the proximate composition of fish fed on macroalgae enriched diets had shown modifications in both body and muscle composition. The addition of the red alga Porphyra purpurea in thick-lipped grey mullet (Chelon labrosus) diets, had significantly 
increased carcass moisture content when compared to no alga inclusion (Davies, Brown and Camilleri, 1997). Other feeding studies have also reported modulation of the whole body and muscle proximate composition including increases in protein (Abdel-warith, Younis and Al-asgah, 2015), lipid (Yone, Furuichi and Urano, 1986; Wan et al., 2016), and ash levels (Abdel-warith et al., 2015, Table 4).

Beside gross influences on the overall nutritional composition, there are also intrinsic modifications within each nutrient group. The alteration of fish muscle amino acid profiles has been thoroughly discussed by Angell et al. (2016), while several other reviews have suggested that seaweeds are excellent sources of $\omega-3$ fatty acids, with a potential to enhance muscle lipid profile with respect to the proportion of $\omega-3$ fatty acid concentration (Macartain et al., 2007; Holdt and Kraan, 2011; Garcia-Vaquero and Hayes, 2015). Indeed, there are fish feed experiments that have reported that an increase in the fish muscle PUFA and $\omega-3$ fatty acid levels at up to $73 \%$ total PUFA and $64 \%$ total $\omega$-3 PUFA (Dantagnan et al., 2009). Up to $17 \%$ higher total $\omega$-3 PUFA in rainbow trout muscle was measured after being fed with dietary supplementation of Ulva spp. (10\%), specifically, this can be attributed to a greater proportion of EPA $(<31 \%)$ and DHA $(<11 \%)$ (Güroy et al., 2012).

Studies have also reported that the dietary seaweed inclusion can alter the colouration of the fed fish. One of the earlier reported studies by Soler-Vila et al. (2009) had observed the inclusion of Porphyra dioica (5-15\%) in rainbow trout (Oncorhynchus mykiss) diets produced pink to orange muscle fillet pigmentation. In comparison, the dietary supplementation of Ulva rigida (5-15\%) had yielded yellow hue in salmon muscle fillets (Moroney et al., 2016). This was also reflected in the use of Palmaria palmata as a supplement in salmon diets, but the level of influence was less profound when contrasted to the dietary inclusion of U. rigida (Moroney et al., 2015). While these studies found the fish pigmentation did not meet market standards, both feeding trials performed 
were void of commercial astaxanthin sources, often synthetic. It is possible that the addition of astaxanthin could restore the pink pigmentation, or require less of the astaxanthin additive to produce a marketable product. It was ascertained that violaxanthin and lutein (xanthophyll) from the dietary inclusion of Ulva spp. was being deposited in the skin tissue of tilapia, which subsequently developed a significant colour change (Valente, Araújo, et al., 2015).

The application of seaweeds for the principal purpose of pigmenting fish could also be applicable to ornamental pet finfish species, where the intensity of the fish colour is often reflected in their traded price. Like in salmonid aquaculture, both synthetically derived and natural sources of xanthophylls are used in ornamental fish diets to enhance skin pigmentation. There have been limited reported studies on the efficacy of seaweeds in conferring pigments onto ornamental fish species. Although, it has been reported that the inclusion of Ulva reticulata (2-8 \%) into goldfish (Carassius auratus) diets had increased body tissue carotenoid concentration by over $40 \%$ (Rama Nisha et al., 2014). As such, exploiting seaweeds in diets for ornamental fish is a potential avenue to explore.

There are also a limited number of studies, which have investigated the effects of seaweed as a source of nutritional macro and trace metals for farmed fish species. In previous reviews, seaweeds have been advocated as an ideal source of trace metals including iodine, manganese, selenium, and zinc (Michalak, Chojnacka and Glavic, 2009; Holdt and Kraan, 2011; Maehre et al., 2014). A thirteen-week feeding trial on rainbow trout had demonstrated that there was a two-fold increase in muscle iodine content in the $5 \%$ dietary inclusion of Gracilaria vermiculophylla treatment group (Valente, Rema, et al., 2015). Similarly, large yellow croaker (Pseudosciaena crocea) had significantly higher carcass levels of copper (242\%), iron (120\%), potassium (133\%), magnesium (146\%) and sodium (204\%) after being fed with Ulva (Enteromorpha) prolifera (15\%) supplemented diet (Asino, Ai and Mai, 2011). Besides nutritional quality assessments, there have been other studies that have examined fish fillet quality with the perspective of shelf-life stability 
(Moroney et al., 2015, 2016), organoleptic (Valente, Araújo, et al., 2015), and muscle structure modifications.

\section{Optimising macroalgae in contemporary aquafeeds}

\subsection{Exploiting seaweeds in compound feeds for fish}

Like many novel feed materials, the commercialisation of a macroalgae species into farmed fish diet would require several salient characteristics:

1. Suitable nutritional profile for the intended fish species;

2. Highly digestible;

3. Limited influence of anti-nutritional factors;

4. Low production cost;

5. Readily available all year round;

6. Sufficient quantities to meet commercial fish feed production levels.

Matching the nutritional compatibility of seaweeds to the requirements of the intended fish could be achieved through selective breeding programs, akin to as those used to create new breeds of plants, i.e. traditional breeding techniques or genetic modification (Halling et al., 2012). In the Far-East, commercial cultivation of the highly demanded Pyropia (nori) for sushi making has been documented since 1670 (Oladokun, Wan-Nik and Kader, 2013). In Japan, in particular, this has led to 30 known cultivars, with certain cultivar lines having traits such as improved seaweed blade length (von de Meer, 1990; Niwa, Furuita and Yamamoto, 2008). Furthermore, with an improved understanding of the sometimes cryptic and complex developmental life-history of seaweeds (e.g. Pyropia), it has allowed phycologists to manipulate algae by producing new morphological hybrid cultivars (Charrier et al., 2015). In addition to their proven efficacy at producing plants with higher crop yields, molecular techniques could also bring a host of other favourable attributes (e.g. improving lipid content, or decreasing carbohydrate levels) by introducing new genes to manufacture a bioactive compound or altering expression of genes or changes to the ploidy 
(Robinson, Winberg and Kirkendale, 2013). Such modifications, however, may pose biosecurity issues through the introduction of foreign genes into local wild algal populations when these are cultivated in an open system or by accidental release (e.g. storm damage or fragmentation during seeding and harvesting). Equally, these concerns were raised by the use of genetically modified microalgae cultivation for biofuel production (Henley et al., 2013). By producing distinct algal cultivars it can lead to a condensed gene pool and increase susceptibility to diseases and environmental change (Halling et al., 2012). If done correctly and with foresight, algal strains could be produced with improved nutritional content that would benefit fish aquaculture by enabling the replacement of unsustainable marine proteins and oils in aqua diets, e.g. pelagic fish species.

An alternative method of augmenting seaweeds in order to meet aquafeed requirements is exposing algae to specific environmental conditions during cultivation. As described earlier, it has been observed that seaweeds can physiologically and metabolically respond to an environmental change. For example, Palmaria palmata is known for its higher protein content during the winter-spring months (Galland-Irmouli et al., 1999), and the presence of elevated nitrogen and phosphate levels in the water column results in increased trace metal content (e.g. cobalt and manganese) in Ulva rigida (Munda and Veber, 2004). It may even be possible to manipulate some algae species prior to harvest to achieve the necessary nutritional improvement with little economic input. For example, it has been reported in several algal species that it is possible to improve lipid content, fatty acid profile, and PUFA levels by simply changing the light intensity (Floreto et al., 1994; Khotimchenko and Yakovleva, 2005; Gosch et al., 2015).

\subsection{Sourcing macroalgae as a feed component}

While nutritional compatibility of a novel feed component is a prerequisite for use in aquafeeds, another factor is sourcing the necessary quantities of the prospective feed ingredient to meet feed manufacturer demand. It has been estimated that 28,000 macroalgae species are known to exist (Guiry, 2012). However only a minority of the seaweeds are found naturally in sufficient amounts 
that could be harvested commercially and meet the proportions needed for aquafeed production (Morand and Merceron, 2005; Thompson et al., 2010; Vea and Ask, 2010; Seeley and Schlesinger, 2012). At present only a fraction of these species are collected at commercial scale, e.g. Ecklonia radiata, Ascophyllum nodosum, Laminaria spp., Lessonia spp. and Macrocystis spp. (ZemkeWhite, Bremner and Hurd, 1999; Vásquez, 2008; Vea and Ask, 2010; Guiry and Morrison, 2013), and these are typically destined for phycocolloid extraction (Bixler and Porse, 2010).

To ensure sustainability and habitat protection, many countries which practice commercial-scale wild seaweed harvesting are regulated by legislation and quotas (Thompson et al., 2010). Set legal harvest limits and harvest management practices are especially important for slower growing species, e.g. Ascophyllum nodosum and kelp species (Vásquez, 2008; Guiry and Morrison, 2013; Maehre et al., 2014). If commercial finfish aquaculture should choose algae as a component in compound feeds, then initially, algae availability would be limited by the 'off-the-shelf' seaweed meals, which are sought after by phycocolloid manufacturers. If demands grow from the feed manufacturers then the competition with the phycocolloid industry could lead to higher market prices for the seaweed and could limit the use of seaweeds in aquafeeds.

It is also important to consider the method of wild harvesting, as a collection from the intertidal zones can invariably incur large labour cost due to labour intensive work, hazardous collection conditions and restrictive tidal conditions. Subtidal macroalgae such as the kelps can be collected through a more automated and mechanical means. These are usually performed on ships with specially adapted collection apparatus, such as the scoubidou in France (SEI, 2009) and seaweed trawlers (Vea and Ask, 2010). The use of these devices has raised concerns over their ability to over-collect and damage the seabed and marine habitats (Hughes et al., 2013). 
Seaweed cultivation could serve as an alternative supply to meet the necessary biomass demands for aquafeed production. Seaweed farming has long been practised in the Far-East, mainly in China, Japan, Malaysia, the Philippines, and South Korea, and has contributed towards a $\$ 6.4$ billion per annum global industry (FAO, 2014). In comparison, macroalgal farming in the western hemisphere has yet to be fully embraced and algal production has so far been limited to wild collections and small scale farms (Vásquez, 2008; Vea and Ask, 2010; Seeley and Schlesinger, 2012; Guiry and Morrison, 2013). Several studies have shown culturing algal species can be successfully performed either at sea (Edwards and Dring, 2011; Peteiro et al., 2013) or in land-based installations (Hafting et al., 2011; Marinho et al., 2013). Furthermore, the success of culturing algae will depend on the life cycle of the algae, with some species such as Euchema and Kappaphycus being easily propagated from break off fronds reattaching to cultivation lines, while species like Laminaria digitata require cultivation through the life-cycle (Edwards and Watson, 2011).

Producing macroalgae meal using Integrated Multi-Trophic Aquaculture (IMTA) systems could also be a viable option, with the intention of mitigating the ecological effects of the highest trophic farmed species, i.e. fish. The concept involves the co-culturing of different trophic-level organisms (e.g. salmon $>$ bivalve $>$ macroalgae) in the same locality, where effluent produced by the highest trophic level (e.g. fish faeces and uneaten food) is taken up by the lower trophic levels as a nutritional source (Troell et al., 2009). These lower trophic levels could include filter feeders, such as bivalve species that could utilise the particulate organic matter (POM), while dissolved organic matter (DOM) is absorbed by the cultured seaweeds. There are many advantages in operating IMTA over monoculture systems, including multiple harvests, increase profitability over a given area and reduction of production cost due to sharing of resources (e.g. boats and labour). While macroalgae that are grown in a high nutrient environment may also bring nutritional advantages compared to stand alone seaweed farms. In an IMTA land-based system (sole and turbot), Gracilaria vermiculophylla had up to $37 \%$ higher nitrogen content in the tissue than their wild population counterparts (Abreu et al., 2011). However, there may be a negative effect on the 
seaweed quality grown in recirculating aquaculture system, as elevated nitrogen and phosphate levels in the water can enhance uptake of metals, particularly toxic elements (Lee and Wang, 2001).

Attaining substantial macroalgae biomass in a short space of time could also be achieved by exploiting algae blooms. A prevalent and significant annual phenomenon, species of Ulva (Zhang et al., 2014), Codium (Israel et al., 2010), Caulerpa (Walters, 2009), and Sargassum (Gower and King, 2011) are the main examples of algae which can proliferate in significant quantities and in a short period of time. Commercial-scale viability is most likely for Ulva and Sargassum blooms because, in some cases, a large biomass can be deposited on the shore by tidal cycles. This has an advantage over collecting from the sea as it allows non-specialised machinery (e.g. farm-yard tractors) to collect the biomass from the shoreline at a relatively low cost (Charlier, Morand and Finkl, 2008).

\subsection{Economic analysis: A case study in the economic value of using Ulva seaweed in aquafeeds.}

Commercial aquafeeds represent a significant cost to a fish farm operation, and the price of FM and FO are the most prominent factor in total feed costs for protein and energy dense feeds as used in the salmon industry (FAO, 2009b). Feed manufacturers must balance between maximising fish growth/health and the cost of the compound feed that the farmer is willing to pay. Less expensive plant meals have been developed as an effective replacer to these expensive fish derived components, and feed manufacturers have greatly benefited through lower feed production cost in meeting the increase in global aquafeed demand (Naylor et al., 2009).

It should be noted that green algae blooms are naturally occurring events in estuarine systems and coastal shores, and unlike terrestrial plant crops, which are also used for replacing FM, they do not 
require energy (e.g. fossil fuels, labour and nutrients) input to grow the biomass. Depending on the country and the labour cost, the price of collecting the bloom can vary. In Ireland, the establishment of the Sea Lettuce Task Force (2010) reported that collecting the Ulva bloom in Courtmacsherry, Ireland (during 2009), would cost 16 euro per metric tonne, while Brittany's Ulva bloom (France) was estimated to range from 7.60 to 122 euro per metric tonne, depending on the area covered and machinery used (Charlier et al., 2007). The removal of the high-water content through drying would be another costly exercise in getting the Ulva to the open market. Blooms which occur in tropical and sub-tropical countries would have a benefit of lower drying cost due to higher irradiance levels and air temperatures, whilst colder climates would incur larger drying cost because of the reliance on fossil fuels for the equivalent high drying air temperatures (Fudholi et al., 2013). Methods of dewatering a large proportion of the water through mechanical treatment could also offer a costeffective means of decreasing water content. These might include mechanical pressing and shredding (Hart et al., 1976).

The primary motivation of using algae in feeds and in many novel feed components is to replace the FM component of the finfish diet. Using a cost-benefit analysis approach, Ulva meal is used here as a case study in evaluating the economic viability of seaweed inclusion in high energy and high protein diets, i.e. salmon compound feed. From the analysis (Table 1), it shows that a formulation model comprising of a $10 \%$ Ulva inclusion level resulted in a saving of $1.27 \% \mathrm{FM}$. This meagre saving is the result of lower protein levels present in Ulva blooms (crude protein $7.69 \%$ in the present study), which is negligible compared to those of other FM alternatives like soya (dehulled, $48.5 \%$ ), canola (38\%) and wheat (12.9\%, Gatlin et al., 2007). Using Scenario 1, where the seaweed is calculated on the basis of collection and processing cost would result in a financial saving of $€ 25.27$ per tonne of fish feed when the Ulva inclusion level was at $10 \%$. However, at the higher $15 \%$ inclusion rate, the cost would result in a greater estimated saving of $€ 111.51$ per tonne of feed. If the Ulva meal was to be purchased from a commercial supplier (Scenario 2), then the financial savings are only apparent with the $15 \%$ inclusion level (€67.78). However, considering 
the amount of aquafeed produced globally, which was estimated at 40 million metric tonnes during 2013, the economic savings of utilising macroalgae are more apparent $(€ 0.93$ billion $=€ 23.21 \times 40$ million, Alltech, 2014). The economical savings will fluctuate depending on a range of factors, which includes the size of the Ulva collection and processing operation, capital equipment prices, fossil fuel and market price of FM. In another study, the use of Ulva (Enteromorpha) intestinalis as a FM replacer in Nile Tilapia (Oreochromis niloticus) fry diet had reduced the feed price by over 15 $\%$ (50\% inclusion), or the cost of feed to produce a kilogram of fish growth by $10.41 \%$ (20\% inclusion) in comparison to FM only diet (Thi et al., 2015).

There are a number of factors which could affect the feasibility of using seaweed in aquafeeds and these are typically driven by market trading forces, which influence FM prices, fossil fuel prices (Table 1), and labour costs (collecting the seaweed). Due to lack of available information, it is not possible to assess the production cost of other seaweed species production systems, such as those produced in open or closed Integrated-Multi-Trophic-Aquaculture systems (IMTA). Production costs can be affected by a multitude of parameters from biological (e.g. growth rate, the level of technical knowledge required), to the economics (e.g. cost of labour, drying cost and capital equipment needed). In comparison with other macroalgal species and especially those produced in aquaculture operations, the cost of purchasing such seaweeds may not be economically as viable as Ulva. It has been reported that the market value for Palmaria palmata ranges from $€ 16,000$ to 18,000 tonne $^{-1}$, and for Laminaria digitata the cost would be estimated at $€ 10,000$ to 16,000 tonne $^{-1}$ (Edwards and Watson, 2011, Watson et al. 2012). However, these values are niche market prices and with increasing seaweed production and more efficient culturing practices production costs could lower to a level that is feasible for aquafeeds. Furthermore, Edwards and Watson (2011) reported that co-culturing seaweeds with scallops on existing mussel cultivation sites would reduce the costs almost two-fold. It is is worth noting that these economic assessments are in the context of seaweeds acting as FM replacer, and it does not take into account the contribution of biologically 
active components (e.g. macro and trace minerals, carotenoids, $\omega$-3 PUFAs, vitamins and antioxidants) that could fortify the aquafeeds and benefit the farmed fish product quality.

\section{Future perspectives of seaweeds as aquafeed components}

There are many qualities of seaweed that might facilitate their exploitation for use as aquafeed components. In recent years, there has been strong interest amongst the European states to develop renewable energy sources using macroalgae as the feedstock (Kraan, 2010; Hughes et al., 2013). With the focus of using algal carbohydrates for producing $3^{\text {rd }}$ generation biofuels, there is an opportunity to exploit the seaweed waste-residue (e.g. proteins, minerals and oils) for aquafeed production (Bikker et al., 2016). Similarly, seaweed waste from phycocolloid production is another prospective feed material (Zhang et al., 2012).

The use of market available phycocolloids could be used as a functional feed component. For example, phycocolloids could be used as feed binders (Dy Peñaflorida and Golez, 1996), as well as encapsulating sensitive compounds in the feed, e.g. medications, enzymes and probiotics (Borgogna, Bellich and Cesàro, 2011). Furthermore, by breaking down these complex carbohydrates, it is possible that the resulting oligosaccharides could have beneficial qualities to fish health by acting as a prebiotic agent (Ramnani et al., 2012). However, the increase in phycocolloid inclusion levels can subsequently alter the physical-chemical properties of the feed, e.g. less resistant to nutrient leaching (Hashim and Saat, 1992). Either through the addition of extracted and refined phycocolloid or through the addition of seaweed into the compound diet, these carbohydrates can act as barriers for normal nutrient absorption through the fish gut.

Like many higher plants, macroalgae can also produce compounds that act as a means of defence or serving a vital function in survival. Examples in macroalgae include phenolics, but many compounds are not well characterised and in particular their effects in finfish. An attempt to process 
raw algae in order to render anti-nutritional components inert has been attempted by Güroy et al. (2012) in autoclaving Ulva meal for use in rainbow trout (Oncorhynchus mykiss) diets. From the experimental feeding trial, the authors found that use of $10 \%$ autoclave treated Ulva meal had led to underperformance in several of the growth indicators when compared to the use of untreated Ulva meal. The observed lowered growth performance could be attributed to destruction of heat labile compounds. Specifically, these are the carotenoids which have been shown to have an antioxidant effect, with the more advantageous property of enhancing growth performance (Torrissen and Christiansen, 1995). Exposure to high temperatures and pro-oxidants can lead to the accelerated carotenoid oxidation, resulting in lower bioactive carotenoid concentrations (Henry et

al., 1998). Further developments in chemical, physical, or biological processing, will be needed for seaweeds to be fully utilised in aquafeeds. Figure 1 shows a roadmap of how seaweeds could be processed from fresh seaweed or waste streams (e.g. phycocolloid manufacturing) into bioactive compounds or feed material that is highly digestible and augment the nutritional composition to meet farmed finfish. Methods of processing could follow similar patterns to those currently applied to terrestrial plant crops. This would reduce the need to develop innovative manufacturing processes, as well as the time needed for research testing to market application, and an overall reducing development cost. In addition, there may be a need for seaweeds to undergo a pretreatment stage, such as particle size reduction for the purpose of increasing the surface to volume ratio, or the removal of salts to prevent interference with the further processing of the seaweed (Kadam, Tiwari and O’Donnell, 2013).

\subsection{Physical processing}

Past investigations have so far comprised of evaluating dried milled seaweed used as a supplement in compound finfish diets. Moreover, there are several studies which have investigated the efficacy of dietary supplementation of extracted seaweed polysaccharides (phycocolloid), where it was found that these complex molecules have the capacity to improve elements of fish health (Caipang et al., 2011; Van Doan, Doolgindachbaporn and Suksri, 2014). Nevertheless, there is a need for 
future research to focus on processing algae meals designed to enhance bioavailability and

digestibility, and therefore, be more appealing for feed manufacturers to adopt as a feed ingredient. Physical processing of seaweeds with the intention of improving digestibility could be attained by a number of methods translated from techniques used to treat higher plants. These include temperature, pressure, extrusion (Vauchel et al., 2008), or a combination of these methods.

At present, there is only one reported study attempting to improve digestibility. The authors examined the merits of using heat, which in higher plants, e.g. soybean meal, has been an effective method of enhancing nutrient digestibility (Zia-ur-Rehman and Salariya, 2005). It is possible that the reduced growth performance reported is due to the degradation of labile compounds such as vitamins, fatty acids, and carotenoids (Gupta, Abu-Ghannam and Rajauria, 2012), which are needed for normal growth. Possibly the autoclave treatment also resulted in the production of free radicals and pro-oxidative products. There are a number of other processing methods (e.g. fermentation, enzymatic hydrolysis, chemical hydrolysis and solvent extraction) that can also be applied to produce highly digestible seaweed products for aquafeed manufacturing.

\subsection{Fermentation}

For centuries, fermentation has been a key method for preserving plant and animal food materials without the need for drying. Using the sugars present in the stock material microbes metabolically convert these molecules into acids, gases and alcohols. This has significant application for seaweeds as fermentation can reduce the number of indigestible complex carbohydrates, which have been shown to reduce nutritional digestibility (Marrion et al., 2003). In addition, fermentation can also decrease ANFs present in plant meals. For example, soybean fermented with Lactobacillus brevis bacteria resulted in an end-product that was void of sucrose and had reduced raffinose and trypsin inhibitor activity (Refstie et al., 2005). Similarly, the fermentation of duckweed (Lemna polyrhiza) 
using isolated microbiota from common carp (Cyprinus carpio) intestine produced negligible amounts of tannins and phytic acid in the fermented meal (Bairagi et al., 2002).

During fermentation, a large amount of cellular water is liberated through the breakdown of the cell walls and cellular membranes (van Laere et al., 2000). This has advantages for seaweed as the large water content present could be removed cheaply by methods such as filtration and pressing rather than the costly method of thermal drying. If needed, dry algae feed material could be attainable with lower energy cost because of the already reduced water content. A typical seaweed drying facility that uses convection heating will be subject to a maximum production limit, i.e. the total amount of seaweeds it can dry in a given period of time. This could be problematic as such facilities would struggle to process large quantities of material collected such as those being generated from algae blooms, and given that algae are highly perishable, much of the algae would rapidly spoil (Hanisak, 1993; Morand and Merceron, 2005).

There are a number of microbes (yeast, fungi, and bacteria) that can be utilised for the fermentation process, but the strains or species used are dependent on the fermentation substrate (Vogel et al., 2007). For instance, Van Laere et al. (2000) studied the fermentation of different plant cell walls and found certain Bifidobacterium spp. were more capable of degrading complex carbohydrates than some of the tested Clostridium species. Lactobacillales is one of the key bacterial Orders that have been heavily used in commercial fermentation processes. Referred to as lactic acid bacteria, the principal advantage of these microbes is their ability to produce copious amounts of lactic acid. The substantial production of lactic acid in the medium can rapidly lower the $\mathrm{pH}(<.5)$ to a point where the growth of pathogens is suppressed, e.g. Salmonoella and Escherichia coli (Lindgren, 1992). Along with the production of other antimicrobial compounds (e.g. carbon dioxide, hydrogen peroxide and bacteriocins), lactic acid bacteria fermentation can extend the shelf-life in the feed material, without the need for drying (Lindgren and Dobrogosz, 1991). 
The use of microbial fermentation on seaweeds can also yield a range of beneficial by-products. Functional improvements such as increased total phenolic and DPPH radical scavenging activity can be observed in Laminaria japonica when subjected to Aspergillus oryzae fungal fermentation (Bae and Kim, 2010). Equally, fermenting Sargassum spp. inoculated with lactic acid bacteria resulted in a two-fold increase in DPPH scavenging activity and hydrogen peroxide scavenging activity (Shobharani, Halami and Sachindra, 2013). The breakdown of the indigestible algal carbohydrates by the microbial community can provide a source of prebiotic (O'Sullivan et al., 2010; Ramnani et al., 2012) and immunostimulatory (Magnadottir et al., 2006; Zhao and Cheung, 2011) products. If the microbiota is kept viable in the fermented seaweed meal (Wu, Wang and Pan, 2007), it is possible the seaweed product could also provide an additional probiotic function. Although, negative changes may also occur such as the breakdown of carotenoids by the microbial community (Mendes-Pinto, 2009).

Seaweeds can be a resistant material for microbial communities to digest. In the case of the three brown algae Himanthalia elongata, Laminaria digitata and Laminaria saccharina, testing showed that it was not possible to sustain lactic bacteria growth without prior processing of the algae, e.g. heat treatment (Gupta, Abu-Ghannam and Scannell, 2011). The resistant nature of seaweed to microbial digestion is a result of high concentrations of heterogeneous complex carbohydrates and the possible presence of anti-microbial compounds (Gupta and Abu-Ghannam, 2011). The use of more compatible microbial strains/communities could enable successful fermentation of the seaweeds. This could be achieved by cultivating the gut flora in marine fish species that have adapted to a natural diet of seaweeds (Ringø and Gatesoupe, 1998; Bairagi et al., 2002; Mountfort, Campbell and Clements, 2002). 


\subsection{Chemical and enzymatic hydrolysis}

Hydrolysis is a process where water is used to chemically break down compounds. Applied to seaweeds, it could have the potential to enhance nutrient bioavailability by breaking the glycosidic linkages between sugar monomers that form the indigestible polysaccharide algal cell wall (Hehemann et al., 2012). These indigestible polysaccharides can be made up by an array such as cellulose, hemicellulose, ulvan and xyloglucan (Lahaye and Robic, 2007; Taboada et al., 2010). By performing hydrolysis on Palmaria palmata, R-phycoerythrin extraction was sixty-two times more efficient than with non-hydrolysed seaweed samples (Dumay et al., 2013) Hydrolysis can be achieved through various means such as physical (e.g. steam and autoclave), chemical (e.g. acid and alkaline) or enzymatic, however, the effectiveness and the end-quality of the resulting feed material differs between methods (Willför et al., 2009). While physical and chemical hydrolysis can be considered an economically cost-effective manufacturing process, it can have a deleterious impact on compounds present in the feed materials. For egg white protein, an increase in chemical hydrolysis resulted in a gradual decline of antioxidant capacity, and angiotensin-converting enzyme (ACE) activity (Chen et al., 2012). Enzymatic hydrolysis carried out on the feed would need to be 'tailored' to suit a specific feed material. For seaweeds, the breakdown of algal cell walls composed of complex heterogeneous polysaccharide structure can interfere with the efficacy of hydrolysis (Jiménez-Escrig and Sánchez-Muniz, 2000). It was demonstrated that by using carbohydrases and proteases in tandem, that the highest amount of antioxidant activity measurement was achieved when compared to singular enzymatic hydrolysis treatment (Siriwardhana et al., 2004).

The use of enzymatic hydrolysis can selectively break down specific compounds present in the seaweed without the need of exposing labile compounds to the destructive conditions. Moreover, enzymatic hydrolysis can allow the recovery of these labile compounds in feed materials, e.g. carotenoids (De Holanda and Netto, 2006). However, utilising enzymes as a means to carry out hydrolysis in feed materials can be a costly process due to the production cost of the enzymes, 
reduced enzyme activity due to inhibitory compounds, and high enzyme-substrate specificity (Hahn-Hägerdal et al., 2006).

The application of hydrolysis can also allow the recovery of proteinaceous materials from proteinrich animal by-products to become viable feed materials. These include fish viscera (Aspmo et al., 2005), terrestrial animal by-products (Fasakin et al., 2005; Sundar et al., 2011), and shellfish waste (De Holanda and Netto, 2006). By applying hydrolysis specifically to the protein component in seaweeds the extraction yield can be substantially enhanced (Galland-Irmouli et al., 1999). Moreover, hydrolysing seaweed proteins can produce peptides that have a variety of positive therapeutic influences, including ACE inhibition, antioxidant, immuno-stimulatory and anticoagulation activities (Harnedy and FitzGerald, 2011; Cian, Martínez-Augustin and Drago, 2012; Samarakoon and Jeon, 2012). At present these functional compounds have yet to be tested in farmed fish, but its integration into feeds may prove to have additional physiological benefits besides providing nutritional sustenance.

\subsection{Extraction systems}

The use of solvent extraction has been traditionally favoured in laboratories and industry as a method of isolating the compound of interest in feed materials and foods. The process is readily applied to separate molecules on the basis of their relative solubility. Solvent extraction is a useful tool in removal of anti-nutrients such as tannins, phytic acid and isothiocyanate in plant meals (Das Purkayastha et al., 2013), or even to decrease the amount of other unwanted compounds in feed materials e.g. carotenoids in maize meal (Park, Flores and Johnson, 1997) and oil content in camelina meal (Ye, Anderson and Lall, 2016). The application of solvent extraction to seaweeds can allow the recovery of nutritional and labile compounds in seaweeds that would otherwise be degraded during the manufacturing processing e.g. drying and milling (Gupta, Cox and AbuGhannam, 2011). Furthermore, by carrying out the extraction prior to seaweeds being used for 
phycococolloid production, a range of secondary high-value products could be generated, e.g. carotenoids, phenolics, lipids, and vitamins (Tierney, Croft and Hayes, 2010). An issue is that the organic solvents (e.g. dichloromethane, hexane and 1,1,1,2-tetrafluoroethane) used for the extraction process can be toxic and/or environmentally damaging and the level of solvent residue in the extracted product is therefore often regulated by legislation, e.g. Directive 2009/32/EC (EU, 2009a).

In Kadam et al's. (2013) review, the authors discuss the alternatives to solvent extraction that could be applied to seaweeds that are both cost-effective and environmentally friendly. These include enzyme-assisted extraction (EAE), microwave-assisted extraction (MAE), ultrasound-assisted extraction (UAE), pressurised liquid extraction (PLE) and supercritical fluid extraction (SFE). Employing carbon dioxide at high pressure, the use of SFE is a highly effective method for the recovery of compounds in algae species. It was reported that $98.7 \%$ lipid yield was recovered from Pavlova spp. microalgae using SFE, while traditional solvent extraction produced under half the yield (Cheng et al., 2011). Similarly, when tested on the brown seaweed Sargassum hemiphyllum, total lipid, total $\omega-3$ and many of the individual fatty acids were extracted at significantly higher concentrations than Soxhlet solvent extraction (Cheung, Leung and Ang, 1998). While each extraction method has provided favourable results compared to solvent extraction, process expense means viability on a commercial scale may be limited to high-value products or compounds that bring a substantial enhancement when fed to the farm finfish, e.g. carotenoids and fatty acids.

\section{Legislation and safety}

Under the EU's Catalogue of Feed Materials (EU Regulation 68/2013, EU, 2013a), seaweeds could be marketed using the term 'seaweed meal', if the product is derived from drying and crushing of macro-algae. However, beyond this, seaweeds which have been subjected to other manufacturing processes would fall under the remit of 'novel feed ingredient', and are therefore subject to 
European Regulation (EC) 767/2009 'the placing on the market and use of feed' (EU, 2009b).

There are no specific restrictions on the species of algae, but all seaweed meal products must declare the crude ash content. The use of calcified macroalgae in the product would also warrant additional feed material naming. Specifically, the catalogue refers these as 'Maerl' or 'Lithothamn' (Phymatolithon calcareum), which are ground or granulated with a declaration of calcium and ash levels.

Beyond these stated feed materials, the catalogue also refers to several feed materials under the term 'Algae' (No. 7.1.1-7.1.5, Regulation 68/2013, EU, 2013a). Although the use of 'Algae' is ambiguous as this can refer to microalgae as well as macroalgae, the series of feed material categories using this term seems to be more relevant to microalgae, e.g. algae oil. Nevertheless, there is a lack of named feed material categories for seaweed products that are derived from manufacturing processes other than dry and milling, e.g. fermentation or hydrolysis. Until revisions are made to account for these materials in the Catalogue of Feed Materials, seaweed feed products will need to notify relevant representatives in the European feed business sector (Regulation (EC) 767/2009, EU, 2009b), and make public the notification on the Feed Materials Register (Feedmaterialsregister.eu). Furthermore, depending on the claims made, seaweed product could be deemed as a 'feed additive' rather than a 'feed material', e.g. 'favourably affect the characteristics of animal product' (2011/25/EU, EU, 2011). If seaweeds were to be deemed an additive then the material will be legislated by Regulation 1831/2003, which requires authorisation from the European Food Safety Authority (EFSA) before products could enter the European market (EU, 2003).

In non-EU nations, regulation of seaweeds as feed materials differs to that of the EU. In Canada, feed materials are governed by the Feeds Regulations, 1983 (SOR/83-593) which permits the use of seaweeds as animal feed components, but is limited to dried and ground algae and is restricted to 
the following macroalgae families: Gelidiaceae, Gigartinaceae, Gracilariaceae, Solieriaceae, Palmariaceae, Bangiaceae, Laminariaceae, Lessoniaceae, Alariaceae, Fucaceae, Sargassaceae, Monostromataceae and Ulvaceae. For algae species, which are not listed, or are derived by a method other than drying and milling, governmental approval will be required (Canada Justice Laws, 2015). While governmental regulations in Australia permit the use of seaweeds in fish diets, registration of the seaweed feed material is required as it is not deemed as 'animal feed materials and ingredients' (i.e. 'they are fed as part of the normal diet of an animal'). As such, seaweed meals will need to conform to regulations under feed medication, supplement or additive (APVMA, 2015). Since the Agricultural and Veterinary Chemicals Legislation Amendment 2015 (F2015L00247, Comlaw, 2015), however, seaweeds could potentially be excluded from the registration if it meets a series of defining parameters (Registration Self-Assessment Tool Veterinary). While, the Food and Drug Administration (FDA), US, recognise most common red (e.g. Porphyra spp., Palmaria palmata) and brown (e.g. Laminaria spp., Macrocystis pyrifera) seaweeds on the GRAS (Generally Recognized As Safe) list are safe for animal feed use (21 CFR184, FDA, 2015).

One of the biggest safety concerns in seaweed use in foods and feeds is the significant metal concentrations that these species can accumulate, in particular, potentially toxic metals, e.g. arsenic, lead and mercury. Current EU regulation concerning contaminants present in feed materials is within the remit of EU Directive 2002/32/EC. The legislation specifically states the maximum legal limit on named substances, and these include: toxic elements (e.g. lead, mercury, arsenic and cadmium), mycotoxins (e.g. aflatoxin), anti-nutritional factors (e.g. gossypol and hydrocyanic acid), and persistent organic pollutants (e.g. DDT, dioxins, and other PCBs, EU, 2002). At present, arsenic is the only named substance that specifically states the maximum level allowed in seaweeds (40 $\left.\mathrm{mg} \mathrm{kg}^{-1}\right)$ and complete feeds with the addition of seaweed material (10 $\mathrm{mg} \mathrm{kg}^{-1}$, Regulation $1275 / 2013, \mathrm{EU}, 2013 \mathrm{~b})$. However, this is with the exception of calcareous algae where arsenic has maximum content of $10 \mathrm{mg} \mathrm{kg}^{-1}$, fluorine $1,000 \mathrm{mg} \mathrm{kg}^{-1}$, and lead $15 \mathrm{mg} \mathrm{kg}^{-1}$. 
Environmental analyses carried out on collected wild seaweeds have shown that macroalgae can potentially accumulate large concentrations of these potentially harmful metals (Malea and Kevrekidis, 2014; Ryan et al., 2012). However, as discussed earlier there are a number of factors that influence the accumulation of metals in seaweeds (Section 2.7). For example, interspecies variability (Ryan, McLoughlin and O’Donovan, 2012) and anthropogenic inputs (Gaudry et al., 2006) have both been shown to affect metal accumulation. While, differences in cultivation method may also have influences on metal accumulation e.g. kelps (Ratcliff et al., 2016). The implications of this on the long-term viability and sustainability of collecting seaweeds for use in aquafeed production can be substantial. At present, there is no legislation in the EU pertaining to a maximum allowable level of any metal in seaweeds in relation to its use in animal feeds or in human foods, with the notable exception of arsenic. Furthermore, any recommended/legislative safe limits for toxic elements in seaweeds, animal feeds or food products are likely to vary between countries and institutions (Table 5). Many of these safe limits only focus on what is considered as 'typical' pollutants: arsenic, mercury, cadmium, chromium, lead and tin. Recent research; however, indicates that other metals (e.g. antimony, silver, thallium and vanadium) could also have damaging health effects when they are present in the environment in even minute quantities (EPA, 2014).

Further investigations are clearly needed to clarify whether arsenic is bioavailable and poses a health risk to farmed animals and humans. For example, in studies such as Rose et al. (2007), the authors reported that commercially available Sargassum fusiforme (hijiki) products in the UK contained high amounts of total arsenic (ranging from 7.9-31 mg kg-1). This was in stark contrast with other seaweed species (Ecklonia bicyclis, Undaria pinnatifida, Saccharina japonica, Pyropia spp.) analysed in the same study, which had typical total arsenic levels ranging from 0.9 to $6.5 \mathrm{mg}$ $\mathrm{kg}^{-1}$. Upon further analysis, much of the arsenic in Sargassum fusiforme was in an inorganic form ( $\sim 71 \%$ of the total arsenic), which is widely accepted as one of the most toxic forms of arsenic. This has led to the UK's Food Standards Agency to issue an advisement against the consumption of 
hijiki (Food Standards Agency, 2010). It would be prudent to fully evaluate new seaweed

candidates for their toxic metal content as well as the chemical species prior to use in animal feeds.

Considered in a wider context, seaweeds are not the only feed material that can contain significant amounts of toxic metals. For example, a survey carried out on Norwegian FMs and FOs found that these products can also be a potential source of arsenic (Sloth, Julshamn and Lundebye, 2005). The average total arsenic reported was $7.7 \mathrm{mg} \mathrm{kg}^{-1}$ in FM and $11.2 \mathrm{mg} \mathrm{kg}^{1}$ in FO with measured inorganic arsenic in the samples representing less than $1.2 \%$ of the total arsenic content.

Nevertheless, the authors noted that such high total arsenic contravened EU's maximum allowable limit in complete feedstuffs for fish and fur animals (10 $\left.\mathrm{mg} \mathrm{kg}^{-1} \mathrm{EU}, 2013\right)$.

\section{Conclusions and a future perspective}

With increasing pressures on global wild fish stocks and arable land, seaweeds could offer a viable alternative and relief to the demands of other ingredients used in aquafeeds. Compared to other aquafeed ingredients, seaweeds offer more than just a supply of nutrients; past studies have identified a number of bioactive compounds in macroalgae that can benefit farmed finfish. As such, these functional compounds could present an attractive incentive to feed manufacturers and fish farmers. This review has shown research on macroalgae as a feed component in finfish diet is still in its infancy. The review has identified a series of knowledge gaps that act as barriers to fully realise macroalgae as a dietary component in commercial aquafeeds. In summary, a number of investigations would be required to appraise and enhance the potential efficacy of seaweeds:

- Removal of anti-nutritional factors from macroalgae that have a negative impact on digestion and growth, e.g. complex carbohydrates and phenolics.

- Methods in reducing complex polysaccharides to enhance nutrient digestibility.

- The breakdown of complex carbohydrates into functional sugars that could offer enhancements to fish health, e.g. prebiotic and immune-stimulants. 
- Improving nutritional content in seaweeds through cultivation methods and favourable trait selection, e.g. higher protein or lipid content.

- Screening, extracting and refining algal bioactive compounds that could have positive influences on farmed finfish species, e.g. growth and health.

- Utilising macroalgae as a functional enhancer on the consumer quality of the fish fillet muscle, e.g. colouration and nutrient content.

With environmental-societal changes and increasing consumer food awareness, the use of seaweeds in farmed fish diets will build a positive image and a goal towards sustainable fish production. This is particularly relevant to sustainable fish farming models such as the concept of integrated multitrophic aquaculture production system.

\section{Acknowledgement}

This review (Grant-Aid Agreement No. MFFRI/07/01) was conducted under the Sea Change Strategy with the support of the Marine Institute and the Department of Agriculture, Food and the Marine, funded under the National Development Plan 2007-2013. The authors would like to knowledge Dr Majbritt Walberg-Bolton, Dr Liam Morrison and Ms Jessica Ratcliff for their editorial reviews. 


\section{Reference}

Abascal, K., Ganora, L. and Yarnell, E. (2005) The effect of freeze-drying and its implications for botanical medicine: a review. Phytotherapy research: PTR, 19(8), pp. 655-60. doi: $10.1002 /$ ptr. 1651 .

Abdel-warith, A. A., Younis, E. M. I. and Al-asgah, N. A. (2015) Potential use of green macroalgae Ulva lactuca as a feed supplement in diets on growth performance, feed utilization and body composition of the African catfish, Clarias gariepinus. Saudi Journal of Biological Sciences. King Saud University, 23(3), pp. 404-409. doi: 10.1016/j.sjbs.2015.11.010.

Abreu, M. H., Pereira, R., Yarish, C., Buschmann, A. H. and Sousa-Pinto, I. (2011) IMTA with Gracilaria vermiculophylla: Productivity and nutrient removal performance of the seaweed in a land-based pilot scale system', Aquaculture. 312(1-4), pp. 77-87. doi:

10.1016/j.aquaculture.2010.12.036.

Adeoye, A. A., Yomla, R., Jaramillo-Torres, A., Rodiles, A., Merrifield, D. L. and Davies, S. J. (2016) Combined effects of exogenous enzymes and probiotic on Nile tilapia (Oreochromis niloticus) growth, intestinal morphology and microbiome, Aquaculture, 463, pp. 61-70. doi: 10.1016/j.aquaculture.2016.05.028.

Akakabe, Y. and Kajiwara, T. (2008) Bioactive volatile compounds from marine algae: feeding attractants. Journal of Applied Phycology, 20(5), pp. 661-664. doi: 10.1007/s10811-0079309-x.

Alamsjah, M. A., Hirao, S., Ishibashi, F., Oda, T. and Fujita, Y. (2007) 'Algicidal activity of polyunsaturated fatty acids derived from Ulva fasciata and U. pertusa (Ulvaceae, Chlorophyta) on phytoplankton. Journal of Applied Phycology, 20(5), pp. 713-720. doi: 10.1007/s10811-007-92575.

Ambati, R. R., Phang, S. M., Ravi, S. and Aswathanarayana, R. G. (2014) Astaxanthin: sources, extraction, stability, biological activities and its commercial applications--a review. Marine drugs, 12(1), pp. 128-52. doi: 10.3390/md12010128.

Andrewes, P., DeMarini, D. M., Funasaka, K., Wallace, K., Lai, V. W. M., Sun, H., Cullen, W. R. and Kitchin, K. T. (2004) Do arsenosugars pose a risk to human health? The comparative toxicities of a trivalent and pentavalent arsenosugar, Environmental Science \& Technology, 38(15), pp. 4140-4148. doi: 10.1021/es035440f.

Angell, A. R., Angell, S. F., de Nys, R. and Paul, N. A. (2016) Seaweed as a protein source for mono-gastric livestock. Trends in Food Science \& Technology. doi: 10.1016/j.tifs.2016.05.014. 
Arsi, M. O. A. L., Lasalvar, C. E. A., Orris, A. N. N. E. M., Aron, M. A. R. K. B. and Hahidi, F. E. S. (2005) Comparison of antioxidant activity, anthocyanins, carotenoids, and phenolics of three native fresh and sun-dried date (Phoenix dactylifera L.) varieties grown in Oman. Journal of Agriculture Food Chemistry, 53(19), pp. 7592-7599. doi: 10.1021/jf050579q.

Asino, H., Ai, Q. and Mai, K. (2011) 'Evaluation of Enteromorpha prolifera as a feed component in large yellow croaker (Pseudosciaena crocea, Richardson, 1846) diets. Aquaculture Research, 42(4), pp. 525-533. doi: 10.1111/j.1365-2109.2010.02648.x.

Bae, H.-N. and Kim, Y.-M. (2010) Improvement of the functional qualities of sea tangle extract through fermentation by Aspergillus oryzae', Fisheries and aquatic sciences, 13(1), pp. 12 17. doi: $10.5657 /$ fas.2010.13.1.012.

Bairagi, A., Sarkar Ghosh, K., Sen, S. K. and Ray, A. K. (2002) 'Duckweed (Lemna polyrhiza) leaf meal as a source of feedstuff in formulated diets for rohu (Labeo rohita Ham.) fingerlings after fermentation with a fish intestinal bacterium. Bioresource Technology, 85(1), pp. 17-24. doi: 10.1016/S0960-8524(02)00067-6.

Besada, V., Andrade, J. M., Schultze, F. and González, J. J. (2009) Heavy metals in edible seaweeds commercialised for human consumption. Journal of Marine Systems. 75(1-2), pp. 305313. doi: 10.1016/j.jmarsys.2008.10.010.

Beyer, P., Al-Babili, S., Ye, X., Lucca, P., Schaub, P., Welsch, R., \& Potrykus, I. (2002). Golden Rice: introducing the beta-carotene biosynthesis pathway into rice endosperm by genetic engineering to defeat vitamin A deficiency. The Journal of Nutrition, 132(3), 506S-510S.

Bikker, P., van Krimpen, M. M., van Wikselaar, P., Houweling-Tan, B., Scaccia, N., van Hal, J. W., Huijgen, W. J. J., Cone, J. W. and López-Contreras, A. M. (2016) Biorefinery of the green seaweed Ulva lactuca to produce animal feed, chemicals and biofuels. Journal of Applied Phycology. doi: 10.1007/s10811-016-0842-3.

Bixler, H. J. and Porse, H. (2010) A decade of change in the seaweed hydrocolloids industry. Journal of Applied Phycology, 23(3), pp. 321-335. doi: 10.1007/s10811-010-9529-3.

Boettcher, A. A. and Targett, N. M. (1993) 'Role of polyphenolic molecular size in reduction of assimilation efficiency in Xiphister Mucosus, Ecology, 74(3), p. 891. doi: $10.2307 / 1940814$.

Borgogna, M., Bellich, B. and Cesàro, A. (2011) Marine polysaccharides in microencapsulation and application to aquaculture: 'from sea to sea'. Marine drugs. 9(12): 25722604 doi: 10.3390/md9122572. 
Le Boucher, R., Dupont-Nivet, M., Vandeputte, M., Kerneïs, T., Goardon, L., Labbé, L., Chatain, B., Bothaire, M. J., Larroquet, L., Médale, F. and Quillet, E. (2012) Selection for adaptation to dietary shifts: towards sustainable breeding of carnivorous fish. PloS one, 7(9), p. e44898. doi: 10.1371/journal.pone.0044898.

Breithaupt, D. E. (2007). Modern application of xanthophylls in animal feeding - a review. Trends in Food Science \& Technology, 18(10), 501-506. doi:10.1016/j.tifs.2007.04.009

Britton, G., Liaaen-Jensen, S. and Pfander, H. (eds) (2008) Carotenoids: Volume 4 Natural functions. Basel: Birkhäuser Basel. doi: 10.1007/978-3-7643-7499-0.

Cabello, F. C. (2006) Heavy use of prophylactic antibiotics in aquaculture: a growing problem for human and animal health and for the environment. Environmental microbiology, 8(7), pp. 1137-44. doi: 10.1111/j.1462-2920.2006.01054.x.

Caipang, C. M. A, Lazado, C. C., Berg, I., Brinchmann, M. F. and Kiron, V. (2011) Influence of alginic acid and fucoidan on the immune responses of head kidney leukocytes in cod. Fish physiology and biochemistry, 37(3), pp. 603-12. doi: 10.1007/s10695-010-9462-z.

Campo, V. L., Kawano, D. F., Silva, D. B. Da and Carvalho, I. (2009) Carrageenans: Biological properties, chemical modifications and structural analysis - A review. Carbohydrate Polymers. 77(2), pp. 167-180. doi: 10.1016/j.carbpol.2009.01.020.

Carreto, J. I. and Carignan, M. O. (2011) Mycosporine-like amino acids: relevant secondary metabolites. Chemical and ecological aspects. Marine drugs, 9(3), pp. 387-446. doi: 10.3390/md9030387.

Castro, R., Piazzon, M. C., Zarra, I., Leiro, J., Noya, M. and Lamas, J. (2006) Stimulation of turbot phagocytes by Ulva rigida C. Agardh polysaccharides, Aquaculture, 254(1-4), pp. 9-20. doi: 10.1016/j.aquaculture.2005.10.012.

Cha, S.-H., Ko, C.-I., Kim, D. and Jeon, Y.-J. (2012) Protective effects of phlorotannins against ultraviolet B radiation in zebrafish (Danio rerio). Veterinary dermatology, 23(1), pp. 51-6, e12. doi: 10.1111/j.1365-3164.2011.01009.x.

Chan, E. W. C., Lim, Y. Y., Wong, S. K., Lim, K. K., Tan, S. P., Lianto, F. S. and Yong, M. Y. (2009) Effects of different drying methods on the antioxidant properties of leaves and tea of ginger species. Food Chemistry. 113(1), pp. 166-172. doi: 10.1016/j.foodchem.2008.07.090.

Chan, J. C.-C., Cheung, P. C.-K. and Ang, P. O. (1997) 'Comparative studies on the effect of three drying methods on the nutritional composition of seaweed Sargassum hemiphyllum (Turn.) C. Ag. Journal of Agricultural and Food Chemistry, 45(8), pp. 3056-3059. doi: 10.1021/jf9701749. 
Charlier, R. H., Morand, P. and Finkl, C. W. (2008) How Brittany and Florida coasts cope with green tides. International Journal of Environmental Studies, 65(2), pp. 191-208. doi: $10.1080 / 00207230701791448$.

Charlier, R. H., Morand, P., Finkl, C. W. and Thys, A. (2007) Green tides on the Brittany coasts. Environmental Research, Engineering and Management, 3(41), pp. 52-59.

Charrier, B., Rolland, E., Gupta, V. and Reddy, C. R. K. (2015) Production of genetically and developmentally modified seaweeds: exploiting the potential of artificial selection techniques. Frontiers in Plant Science, 6. doi: 10.3389/fpls.2015.00127.

Chen, C., Chi, Y. J., Zhao, M. Y. and Xu, W. (2012) 'Influence of degree of hydrolysis on functional properties, antioxidant and ACE inhibitory activities of egg white protein hydrolysate', Food Science and Biotechnology, 21(1), pp. 27-34. doi: 10.1007/s10068-012-0004-6.

Cheng, A.-C., Chen, Y.-Y. and Chen, J.-C. (2008) Dietary administration of sodium alginate and kappa-carrageenan enhances the innate immune response of brown-marbled grouper Epinephelus fuscoguttatus and its resistance against Vibrio alginolyticus. Veterinary immunology and immunopathology, 121(3-4), pp. 206-15. doi: 10.1016/j.vetimm.2007.09.011.

Cheng, C.-H., Du, T.-B., Pi, H.-C., Jang, S.-M., Lin, Y.-H. and Lee, H.-T. (2011) Comparative study of lipid extraction from microalgae by organic solvent and supercritical CO2. Bioresource Technology. 102(21), pp. 10151-10153. doi: 10.1016/j.biortech.2011.08.064.

Cheung, P. C. K., Leung, A. Y. H. and Ang, P. O. (1998) Comparison of supercritical carbon dioxide and soxhlet extraction of lipids from a brown seaweed, Sargassum hemiphyllum (Turn.) C. Ag. Journal of Agricultural and Food Chemistry, 46(10), pp. 4228-4232. doi: 10.1021/jf980346h.

Choi, Y. H., Lee, B.-J. and Nam, T. J. (2015) 'Effect of dietary inclusion of Pyropia yezoensis extract on biochemical and immune responses of olive flounder Paralichthys olivaceus. Aquaculture. 435, pp. 347-353. doi: 10.1016/j.aquaculture.2014.10.010.

Christaki, E., Bonos, E., Giannenas, I. and Florou-Paneri, P. (2012) Functional properties of carotenoids originating from algae. Journal of the science of food and agriculture, 93, pp. 5-11. doi: 10.1002/jsfa.5902.

Cian, R. E., Martínez-Augustin, O. and Drago, S. R. (2012) Bioactive properties of peptides obtained by enzymatic hydrolysis from protein byproducts of Porphyra columbina. Food Research International. 49(1), pp. 364-372. doi: 10.1016/j.foodres.2012.07.003. 
Coelho, J. P., Pereira, M. E., Duarte, A. and Pardal, M. A. (2005) Macroalgae response to a mercury contamination gradient in a temperate coastal lagoon (Ria de Aveiro, Portugal). Estuarine, Coastal and Shelf Science, 65(3), pp. 492-500. doi: 10.1016/j.ecss.2005.06.020.

Cofrades, S., López-López, I., Bravo, L., Ruiz-Capillas, C., Bastida, S., Larrea, M. T. and Jiménez-Colmenero, F. (2010) Nutritional and antioxidant properties of different brown and red Spanish edible seaweeds. Food science and technology international, 16(5), pp. 361-70. doi: $10.1177 / 1082013210367049$.

Cruces, E., Huovinen, P. and Gómez, I. (2012) Stress proteins and auxiliary anti-stress compounds in intertidal macroalgae Proteínas de estrés y compuestos anti-estrés auxiliares en algas marinas intermareales. 40(4), pp. 822-834.

Dagnelie, C., WAV, S. and H, van der B. (1991) Vitamin B-12 from algae appears not to be bioavailable. The American Journal of Clinical Nutrition, 53(3), pp. 695-697.

Dalmo, R. A. and Seljelid, R. (1995) The immunomodulatory effect of LPS, laminaran and sulphated laminaran [3 (1, 3) -D-glucan] on Atlantic salmon, Salmo salar L ., macrophages in vitro. Journal of fish diseases, 18(2), pp. 175-185.

Dantagnan, P., HernÃ indez, A., Borquez, A. and Mansilla, A. (2009) 'Inclusion of macroalgae meal (Macrocystis pyrifera) as feed ingredient for rainbow trout (Oncorhynchus mykiss): effect on flesh fatty acid composition. Aquaculture Research, 41(1), pp. 87-94. doi: 10.1111/j.1365-2109.2009.02308.x.

Davies, S. J., Brown, M. T. and Camilleri, M. (1997) Preliminary assessment of the seaweed Porphyra purpurea in artificial diets for thick-lipped grey mullet (Chelon labrosus). Aquaculture, 152(1-4), pp. 249-258. doi: 10.1016/S0044-8486(96)01513-X.

Davis, T. A, Volesky, B. and Mucci, A. (2003) A review of the biochemistry of heavy metal biosorption by brown algae. Water research, 37(18), pp. 4311-30. doi: 10.1016/S00431354(03)00293-8.

Dawczynski, C., Schäfer, U., Leiterer, M. and Jahreis, G. (2007) Nutritional and toxicological importance of macro, trace, and ultra-trace elements in algae food products. Journal of Agricultural and Food Chemistry, 55(25), pp. 10470-5. doi: 10.1021/jf0721500.

Dethier, M. N., Williams, S. L. and Freeman, A. (2005) 'Seaweeds under stress: Manipulated stress and herbivory affect critical life-history functions.', Ecological Monographs, 75(3), pp. 403-418. doi: 10.1890/03-4108. 
Díaz-Rosales, P., Felices, C., Abdala, R., Figueroa, F. L., Gómez Pinchetti, J. L., Moriñigo, M. A and Balebona, M. C. (2007) In vitro effect of the red alga Hydropuntia cornea (J. Agardh) on the respiratory burst activity of sole (Solea senegalensis, Kaup 1858) phagocytes. Aquaculture Research, 38(13), pp. 1411-1418. doi: 10.1111/j.1365-2109.2007.01830.x.

Dierick, N., Ovyn, A. and De Smet, S. (2009) Effect of feeding intact brown seaweed Ascophyllum nodosum on some digestive parameters and on iodine content in edible tissues in pigs. Journal of the Science of Food and Agriculture, 89(4), pp. 584-594. doi: 10.1002/jsfa.3480.

van Doan, H., Doolgindachbaporn, S. and Suksri, A. (2014) Effects of low molecular weight agar and Lactobacillus plantarum on growth performance, immunity, and disease resistance of basa fish (Pangasius bocourti, Sauvage 1880). Fish \& shellfish immunology. 41(2), pp. 340-345. doi: 10.1016/j.fsi.2014.09.015.

Drew, M. D., Borgeson, T. L. and Thiessen, D. L. (2007) A review of processing of feed ingredients to enhance diet digestibility in finfish. Animal Feed Science and Technology, 138(2), pp. 118-136. doi: 10.1016/j.anifeedsci.2007.06.019.

Dy Peñaflorida, V. and Golez, N. V. (1996) Use of seaweed meals from Kappaphycus alvarezii and Gracilaria heteroclada as binders in diets for juvenile shrimp Penaeus monodon, Aquaculture, 143(3-4), pp. 393-401. doi: 10.1016/0044-8486(96)01282-3.

Edwards, M. D. and Dring, M. J. (2011) Open-sea cultivation trial of the red alga, Palmaria palmata from seeded tetraspores in Strangford Lough, Northern Ireland. Aquaculture. 317(1-4), pp. 203-209. doi: 10.1016/j.aquaculture.2011.04.007.

Edwards, M. and Watson, L. (2011) Aquaculture Explained No. 26 Cultivating Lamineria digitata. BIM. Available at: http://www.bim.ie/media/bim/content/publications/BIM,Aquaculture,Explained,Issue,26,,Cultivating,Laminaria,digitata.pdf

EU (2002) Directive 2002/32/EC of the European Parliament and of the Council of 7 May 2002 on undesirable substances in animal feed. Available at: http://eurlex.europa.eu/resource.html?uri=cellar:aca28b8c-bf9d-444f-b470$\underline{268 f 71 \mathrm{df} 28 \mathrm{fb} .0004 .02 / \mathrm{DOC} \_1 \& \text { format=PDF. }}$

FAO (2009a) How to Feed the World in 2050, Food agriculture organisation of the United Nations. Available at: http://www.fao.org/fileadmin/templates/wsfs/docs/expert_paper/How_to_Feed_the_World_in_2050 .pdf. 
FAO (2009b) Impact of rising feed ingredient prices on aquafeeds and aquaculture production. Available at: www.fao.org/docrep/012/i1143e/i1143e00.htm.

FAO (2016) The State of World Fisheries and Aquaculture 2016. Available at: http://www.fao.org/3/a-i5555e.pdf

FDA (2015) 'Microorganisms \& microbial-derived ingredients used in food' Available at https://www.fda.gov/food/ingredientspackaginglabeling/gras/microorganismsmicrobialderivedingre dients/default.htm (Accessed: 11 October 2017)

FDA (2013), Code of federal regulations title 21 URL:

http://www.accessdata.fda.gov/scripts/cdrh/cfdocs/cfcfr/CFRSearch.cfm?fr=73.35

Fleurence, J. (1999) Seaweed proteins: biochemical, nutritional aspects and potential uses. Trends in Food Science \& Technology, 10, pp. 26-29. Available at: http://www.sciencedirect.com/science/article/pii/S0924224499000151 (Accessed: 11 October 2017).

Floreto, E. A. T., Hirata, H., Yamasaki, S. and Castro, S. C. (1994) 'Influence of light intensity on the fatty acid composition of Ulva pertusa Kjellman (Chlorophyta)', Botanica Marina, 37(2), pp. 143-149. doi: 10.1515/botm.1994.37.2.143.

Floreto, E. A. T. and Teshima, S. (1998) The fatty acid composition of seaweed exposed to different levels of light intensity and salinity. Botanica Marina, 41, pp. 467-481. Available at: c:\%5CArchivos de programa\%5CEndNote\%5CBASES DE DATOS\%5CArticulosenPDF\%5C957Floreto_1998.pdf.

Francis, G., Makkar, H. P. and Becker, K. (2001) Antinutritional factors present in plantderived alternate fish feed ingredients and their effects in fish, Aquaculture. doi: 10.1016/S00448486(01)00526-9.

Fudholi, A., Sopian, K., Othman, M. Y. and Ruslan, M. H. (2013) Energy and exergy analyses of solar drying system of red seaweed. Energy and Buildings. doi: 10.1016/j.enbuild.2013.07.072.

Gakkaishi, N. S., Satoh, K. and Test, C. (1987) Effect of Ulva meal supplementation on disease resistance of red sea bream, Nippon Suisan Gakkaishi, 53(7), pp. 1115-1120. Available at: https://www.jstage.jst.go.jp/article/suisan1932/53/7/53_7_1115/_pdf.

Galland-Irmouli, A. V, Fleurence, J., Lamghari, R., Luçon, M., Rouxel, C., Barbaroux, O., Bronowicki, J. P., Villaume, C. and Guéant, J. L. (1999) 'Nutritional value of proteins from edible 
seaweed Palmaria palmata (dulse).', The Journal of nutritional biochemistry, 10(6), pp. 353-9. Available at: http://www.ncbi.nlm.nih.gov/pubmed/15539310.

García-Sartal, C., Barciela-Alonso, M. D. C., Moreda-Piñeiro, A. and Bermejo-Barrera, P. (2013) Study of cooking on the bioavailability of $\mathrm{As}, \mathrm{Co}, \mathrm{Cr}, \mathrm{Cu}, \mathrm{Fe}, \mathrm{Ni}$, Se and $\mathrm{Zn}$ from edible seaweed. Microchemical Journal. 108, pp. 92-99. doi: 10.1016/j.microc.2012.10.003.

Garcia-Vaquero, M. and Hayes, M. (2015) Red and Green Macroalgae for fish, animal feed and human functional food development. Food Reviews International, p. 150731081459001. doi: $10.1080 / 87559129.2015 .1041184$.

Gatlin, D. M., Barrows, F. T., Brown, P., Dabrowski, K., Gaylord, T. G., Hardy, R. W., Herman, E., Hu, G., Krogdahl, Å., Nelson, R., Overturf, K., Rust, M., Sealey, W., Skonberg, D., J Souza, E., Stone, D., Wilson, R. and Wurtele, E. (2007) Expanding the utilization of sustainable plant products in aquafeeds: a review. Aquaculture Research, 38(6), pp. 551-579. doi: 10.1111/j.1365-2109.2007.01704.x.

Gaudry, A., Zeroual, S., Gaie-Levrel, F., Moskura, M., Boujrhal, F.-Z., El Moursli, R. C., Guessous, A., Mouradi, A., Givernaud, T. and Delmas, R. (2006) Heavy metals pollution of the atlantic marine environment by the moroccan phosphate industry, as observed through their bioaccumulation in Ulva Lactuca. Water, Air, and Soil Pollution, 178(1-4), pp. 267-285. doi: 10.1007/s11270-006-9196-9.

Gawlicka, A., McLaughlin, L., Hung, S. S. O. and de la Noüe, J. (1996) Limitations of carrageenan microbound diets for feeding white sturgeon, Acipenser transmontanus, larvae. Aquaculture, 141(3-4), pp. 245-265. doi: 10.1016/0044-8486(95)01220-6.

Goñi, I., Gudiel-Urbano, M., Bravo, L. and Saura-Calixto, F. (2001) Dietary modulation of bacterial fermentative capacity by edible seaweeds in rats. Journal of agricultural and food chemistry, 49(5), pp. 2663-8. Available at: http://www.ncbi.nlm.nih.gov/pubmed/11368652.

Gosch, B. J., Lawton, R. J., Paul, N. a., de Nys, R. and Magnusson, M. (2015) Environmental effects on growth and fatty acids in three isolates of Derbesia tenuissima (Bryopsidales, Chlorophyta). Algal Research. 9, pp. 82-93. doi: 10.1016/j.algal.2015.02.022.

Gosch, B. J., Magnusson, M., Paul, N. A. and de Nys, R. (2012) Total lipid and fatty acid composition of seaweeds for the selection of species for oil-based biofuel and bioproducts. GCB Bioenergy, 4(6), pp. 919-930. doi: 10.1111/j.1757-1707.2012.01175.x.

Gower, J. F. R. and King, S. A. (2011) Distribution of floating Sargassum in the Gulf of Mexico and the Atlantic Ocean mapped using MERIS. International Journal of Remote Sensing, 32(7), pp. 1917-1929. doi: 10.1080/01431161003639660. 
Gressler, V., Yokoya, N. S., Fujii, M. T., Colepicolo, P., Filho, J. M., Torres, R. P. and Pinto, E. (2010) 'Lipid, fatty acid, protein, amino acid and ash contents in four Brazilian red algae species. Food Chemistry, 120(2), pp. 585-590. doi: 10.1016/j.foodchem.2009.10.028.

Guillaume, J., Kaushik, S., Bergot, P. and Metailler, R. (2001) Nutrition and feeding of fish and crustaceans. Springer-Verlag London.

Guiry, M. D. (2012) 'How many species of algae are there?', Journal of Phycology, 48(5), pp. 1057-1063. doi: 10.1111/j.1529-8817.2012.01222.x.

Guiry, M. D. and Morrison, L. (2013) The sustainable harvesting of Ascophyllum nodosum (Fucaceae, Phaeophyceae) in Ireland, with notes on the collection and use of some other brown algae. Journal of Applied Phycology, 25(6), pp. 1823-1830. doi: 10.1007/s10811-013-0027-2.

Gupta, S. and Abu-Ghannam, N. (2011) Recent developments in the application of seaweeds or seaweed extracts as a means for enhancing the safety and quality attributes of foods', Innovative Food Science \& Emerging Technologies. Elsevier Ltd, 12(4), pp. 600-609. doi: 10.1016/j.ifset.2011.07.004.

Gupta, S., Abu-Ghannam, N. and Rajauria, G. (2012) Effect of heating and probiotic fermentation on the phytochemical content and antioxidant potential of edible Irish brown seaweeds, Botanica Marina, 55(5), pp. 527-537. doi: 10.1515/bot-2011-0052.

Gupta, S., Abu-Ghannam, N. and Scannell, A. G. M. (2011) Growth and kinetics of Lactobacillus plantarum in the fermentation of edible Irish brown seaweeds. Food and Bioproducts Processing. Institution of Chemical Engineers, 89(4), pp. 346-355. doi: 10.1016/j.fbp.2010.10.001.

Gupta, S., Cox, S. and Abu-Ghannam, N. (2011) 'Effect of different drying temperatures on the moisture and phytochemical constituents of edible Irish brown seaweed', LWT - Food Science and Technology. Elsevier Ltd, 44(5), pp. 1266-1272. doi: 10.1016/j.lwt.2010.12.022.

Güroy, B., Ergün, S., Merrifield, D. L. and Güroy, D. (2012) Effect of autoclaved Ulva meal on growth performance, nutrient utilization and fatty acid profile of rainbow trout, Oncorhynchus mykiss. Aquaculture International, 21(3), pp. 605-615. doi: 10.1007/s10499-012-9592-7.

Guzmán-Villanueva, L. T., Tovar-Ramírez, D., Gisbert, E., Cordero, H., Guardiola, F. a, Cuesta, A., Meseguer, J., Ascencio-Valle, F. and Esteban, M. A (2014) Dietary administration of $\beta$ 1,3/1,6-glucan and probiotic strain Shewanella putrefaciens, single or combined, on gilthead seabream growth, immune responses and gene expression. Fish \& shellfish immunology. 39(1), pp. 34-41. doi: 10.1016/j.fsi.2014.04.024. 
Gyurcsik, B. and Nagy, L. (2000) 'Carbohydrates as ligands: coordination equilibria and structure of the metal complexes', Coordination Chemistry Reviews, 203(1), pp. 81-149. doi: 10.1016/S0010-8545(99)00183-6.

Hafting, J. T., Critchley, A. T., Cornish, M. L., Hubley, S. A. and Archibald, A. F. (2011) On-land cultivation of functional seaweed products for human usage. Journal of Applied Phycology, 24(3), pp. 385-392. doi: 10.1007/s10811-011-9720-1.

Hahn-Hägerdal, B., Galbe, M., Gorwa-Grauslund, M. F., Lidén, G. and Zacchi, G. (2006) Bio-ethanol - the fuel of tomorrow from the residues of today. Trends in Biotechnology, 24(12), pp. 549-556. doi: 10.1016/j.tibtech.2006.10.004.

Halling, C., Wikström, S. A., Lilliesköld-Sjöö, G., Mörk, E., Lundsør, E. and Zuccarello, G. C. (2012) Introduction of Asian strains and low genetic variation in farmed seaweeds: indications for new management practices. Journal of Applied Phycology, 25(1), pp. 89-95. doi: 10.1007/s10811-012-9842-0.

Hanisak, M. D. (1993) Nitrogen release from decomposing seaweeds: species and temperature effects. Journal of Applied Phycology, 5(2), pp. 175-181. doi: 10.1007/BF00004014.

Harnedy, P. A. and FitzGerald, R. J. (2011) Bioactive proteins, peptides, and amino acids from macroalgae. Journal of Phycology, 47(2), pp. 218-232. doi: 10.1111/j.15298817.2011.00969.x.

Hart, M. R., De, D., Lyon, C. K. and Kohler, G. O. (1976) Dewatering kelp for fuel, feed, and food uses: Process description and material balances. Transaction of the ASAE, 21, pp. 186196.

Harvey, M. and Pilgrim, S. (2011) The new competition for land: Food, energy, and climate change. Food Policy. 36, pp. S40-S51. doi: 10.1016/j.foodpol.2010.11.009.

Hashim, R. and Saat, M. A. M. (1992) The utilization of seaweed meals as binding agents in pelleted feeds for snakehead (Channa striatus) fry and their effects on growth. Aquaculture, 108(34), pp. 299-308. doi: 10.1016/0044-8486(92)90114-Z.

Hehemann, J. H., Smyth, L., Yadav, A., Vocadlo, D. J. and Boraston, A. B. (2012) Analysis of keystone enzyme in agar hydrolysis provides insight into the degradation of a polysaccharide from red seaweeds. Journal of Biological Chemistry, 287(17), pp. 13985-13995. doi: 10.1074/jbc.M112.345645. 
Henley, W. J., Litaker, R. W., Novoveská, L., Duke, C. S., Quemada, H. D. and Sayre, R. T. (2013) Initial risk assessment of genetically modified (GM) microalgae for commodity-scale biofuel cultivation. Algal Research. 2(1), pp. 66-77. doi: 10.1016/j.algal.2012.11.001.

Hidalgo, M. C., Urea, E. and Sanz, A. (1999) Comparative study of digestive enzymes in fish with different nutritional habits. Proteolytic and amylase activities. Aquaculture, 170(3-4), pp. 267-283. doi: 10.1016/S0044-8486(98)00413-X.

de Holanda, H. D. and Netto, F. M. (2006) Recovery of components from shrimp (Xiphopenaeus kroyeri) processing waste by enzymatic hydrolysis. Journal of Food Science, 71(5), pp. 298-303. doi: 10.1111/j.1750-3841.2006.00040.x.

Holdt, S. L. and Kraan, S. (2011) Bioactive compounds in seaweed: functional food applications and legislation. Journal of Applied Phycology, 23(3), pp. 543-597. doi: 10.1007/s10811-010-9632-5.

Hughes, A. D., Black, K. D., Campbell, I., Heymans, J. J., Orr, K. K., Stanley, M. S. and Kelly, M. S. (2013) Comments on "Prospects for the use of macroalgae for fuel in Ireland and UK: An overview of marine management issues”. Marine Policy. Elsevier, 38, pp. 554-556. doi: 10.1016/j.marpol.2012.08.001.

Ibañez, E. and Cifuentes, A. (2013) Benefits of using algae as natural sources of functional ingredients. Journal of the science of food and agriculture, 93(4), pp. 703-9. doi: 10.1002/jsfa.6023.

Ishihara, K., Oyamada, C., Sato, Y., Suzuki, T., Kaneniwa, M., Kunitake, H. and Muraoka, T. (2010) Prebiotic effect of glycerol galactoside isolated from color-faded nori in rats. Fisheries Science, 76(6), pp. 1015-1021. doi: 10.1007/s12562-010-0298-3.

Israel, A., Einav, R., Silva, P. C., Paz, G., Chacana, M. E. and Douek, J. (2010) First report of the seaweed Codium parvulum (Chlorophyta) in Mediterranean waters: recent blooms on the northern shores of Israel. Phycologia, 49(2), pp. 107-112. doi: 10.2216/PH09-28.1.

Jiménez-Escrig, A. and Sánchez-Muniz, F. J. (2000) Dietary fibre from edible seaweeds: Chemical structure, physicochemical properties and effects on cholesterol metabolism. Nutrition Research, 20(4), pp. 585-598. doi: 10.1016/S0271-5317(00)00149-4.

von de Meer, J.P. (1990) Genetics, in KM, C. and RG, S. (eds) Biology of the red algae. Cambridge University Press, Cambridge, pp. 103-120. doi: 10.1046/j.1420-9101.1992.5030533.x.

Kadam, S. U., Tiwari, B. K. and O’Donnell, C. P. (2013) Application of novel extraction technologies for bioactives from marine algae. Journal of Agricultural and Food Chemistry, 61(20), pp. 4667-4675. doi: 10.1021/jf400819p. 
Kalla, A., Yoshimatsu, T., Araki, T., Zhang, D.-M., Yamamoto, T. and Sakamoto, S. (2008) Use of Porphyra spheroplasts as feed additive for red sea bream. Fisheries Science, 74(1), pp. 104108. doi: 10.1111/j.1444-2906.2007.01501.x.

Kamalam, B. S., Medale, F. and Panserat, S. (2015) Utilisation of dietary carbohydrates in farmed fishes: New insights on influencing factors, biological limitations and future strategies. Aquaculture. doi: 10.1016/j.aquaculture.2016.02.007.

Kang, M.-C., Cha, S. H., Wijesinghe, W. a J. P., Kang, S.-M., Lee, S.-H., Kim, E.-A., Song, C. B. and Jeon, Y.-J. (2013) Protective effect of marine algae phlorotannins against AAPH-induced oxidative stress in zebrafish embryo. Food chemistry, 138(2-3), pp. 950-5. doi: 10.1016/j.foodchem.2012.11.005.

Karsten, U., Mostaerti, A. S., King, R. J., Kamiya, M. and Hara, Y. (1996) Osmoprotectors in some species of Japanese mangrove macroalgae. 44(2) pp. 109-112.

Khotimchenko, S. V and Yakovleva, I. M. (2005) Lipid composition of the red alga Tichocarpus crinitus exposed to different levels of photon irradiance. Phytochemistry, 66(1), pp. 73-9. doi: 10.1016/j.phytochem.2004.10.024.

Kindleysides, S., Quek, S.-Y. and Miller, M. R. (2012) Inhibition of fish oil oxidation and the radical scavenging activity of New Zealand seaweed extracts. Food Chemistry. 133(4), pp. 1624-1631. doi: 10.1016/j.foodchem.2012.02.068.

Kraan, S. (2010) Mass-cultivation of carbohydrate rich macroalgae, a possible solution for sustainable biofuel production, Mitigation and Adaptation Strategies for Global Change, 18(1), pp. 27-46. doi: 10.1007/s11027-010-9275-5.

Krogdahl, A., Hemre, G.-I. and Mommsen, T. P. (2005) Carbohydrates in fish nutrition: digestion and absorption in postlarval stages. Aquaculture Nutrition, 11(2), pp. 103-122. doi: 10.1111/j.1365-2095.2004.00327.x.

van Laere, K. M. J., Hartemink, R., Bosveld, M., Schols, H. A. and Voragen, A. G. J. (2000) Fermentation of plant cell wall derived polysaccharides and their corresponding oligosaccharides by intestinal bacteria. Journal of Agricultural and Food Chemistry, 48(5), pp. 1644-1652. doi: 10.1021/jf990519i.

Lahaye, M. and Robic, A. (2007) Structure and functional properties of ulvan, a polysaccharide from green seaweeds. Biomacromolecules, 8(6), pp. 1765-74. doi: $10.1021 / \mathrm{bm} 061185 \mathrm{q}$. 
Lall, S. P. (2003) The Minerals. In Fish Nutrition. Elsevier, pp. 259-308. doi: 10.1016/B978-012319652-1/50006-9.

Lam, K.-L. and Chi-Keung Cheung, P. (2013) Non-digestible long chain beta-glucans as novel prebiotics. Bioactive Carbohydrates and Dietary Fibre. 2(1), pp. 45-64. doi: 10.1016/j.bcdf.2013.09.001.

Lee, W.-Y. and Wang, W.-X. (2001) Metal accumulation in the green macroalga Ulva fasciata: effects of nitrate, ammonium and phosphate. Science of The Total Environment, 278(1-3), pp. 11-22. doi: 10.1016/S0048-9697(00)00884-6.

Lindgren, S. E. and Dobrogosz, W. J. (1991) Antagonistic activities of lactic acid bacteria in food and feed fermentations. FEMS Microbiology Letters, 87(1-2), pp. 149-163. doi: 10.1016/0378-1097(90)90703-S.

Liu, M., Hansen, P. E. and Lin, X. (2011) Bromophenols in marine algae and their bioactivities. Marine drugs, 9(7), pp. 1273-92. doi: 10.3390/md9071273.

Lundebye, A.-K., Berntssen, M. H., Bonga, S. E. W. and Maage, A (1999) Biochemical and physiological responses in Atlantic salmon (Salmo salar) following dietary exposure to copper and cadmium. Marine Pollution Bulletin, 39(1-12), pp. 137-144. doi: 10.1016/S0025-326X(98)002082.

Ma, W. C. J., Chung, H. Y., Ang, P. O. and Kim, J.-S. (2005) Enhancement of bromophenol levels in aquacultured silver seabream (Sparus sarba). Journal of agricultural and food chemistry, 53(6), pp. 2133-9. doi: 10.1021/jf048390m.

Macartain, P., Gill, C. I. R., Brooks, M., Campbell, R. and Rowland, I. R. (2007) Nutritional Value of Edible Seaweeds. 65(12), pp. 535-543. doi: 10.1301/nr.2007.dec.535.

Maehre, H. K., Malde, M. K., Eilertsen, K.-E. and Elvevoll, E. O. (2014) Characterization of protein, lipid and mineral contents in common Norwegian seaweeds and evaluation of their potential as food and feed. Journal of the Science of Food and Agriculture, 94(15), pp. 3281-3290. doi: $10.1002 /$ jsfa.6681.

Magnadóttir, B. (2006) Innate immunity of fish (overview). Fish \& shellfish immunology, 20(2), pp. 137-51. doi: 10.1016/j.fsi.2004.09.006.

Magnadottir, B., Gudmundsdottir, B. K., Lange, S., Steinarsson, A., Oddgeirsson, M., Bowden, T., Bricknell, I., Dalmo, R. A and Gudmundsdottir, S. (2006) Immunostimulation of larvae and juveniles of cod, Gadus morhua L. Journal of fish diseases, 29(3), pp. 147-55. doi: 10.1111/j.1365-2761.2006.00701.x. 
Malea, P., Haritonidis, S. and Kevrekidis, T. (1995) Metal content of some green and brown seaweeds from Antikyra Gulf (Greece), Hydrobiologia, 310(1), pp. 19-31. doi:

10.1007/BF00008180.

Malea, P. and Kevrekidis, T. (2014) 'Trace element patterns in marine macroalgae.', The Science of the total environment. Elsevier B.V., 494-495C, pp. 144-157. doi:

10.1016/j.scitotenv.2014.06.134.

Mamboya, F., Lyimo, T. J., Landberg, T. and Björk, M. (2009) Influence of combined changes in salinity and copper modulation on growth and copper uptake in the tropical green macroalga Ulva reticulate. Estuarine, Coastal and Shelf Science. 84(3), pp. 326-330. doi: 10.1016/j.ecss.2009.03.034.

Maoka, T. (2011) Carotenoids in marine animals. Marine drugs, 9(2), pp. 278-93. doi: $10.3390 / \mathrm{md} 9020278$.

Marinho, G., Nunes, C., Sousa-Pinto, I., Pereira, R., Rema, P. and Valente, L. M. P. (2013) The IMTA-cultivated Chlorophyta Ulva spp. as a sustainable ingredient in Nile tilapia (Oreochromis niloticus) diets. Journal of Applied Phycology, 25(5), pp. 1359-1367. doi: 10.1007/s10811-012-9965-3.

Marrion, O., Schwertz, A., Fleurence, J., Guéant, J. L. and Villaume, C. (2003) Improvement of the digestibility of the proteins of the red alga Palmaria palmata by physical processes and fermentation. Die Nahrung, 47(5), pp. 339-44. doi: 10.1002/food.200390078.

Martínez, B. and Rico, J. M. (2002) Seasonal variation of P content and major N pools in Palmaria palmata (rhodophyta). Journal of Phycology, 38(6), pp. 1082-1089. doi: 10.1046/j.15298817.2002.01217.x.

McDermid, K. J. and Stuercke, B. (2003) Nutritional composition of edible Hawaiian seaweeds. Journal of Applied Phycology, 15(6), pp. 513-524. doi:

10.1023/B:JAPH.0000004345.31686.7f.

McHugh, D. (2003) A guide to the seaweed industry. Available at: www.fao.org/3/ay4765e.

Meena, D. K., Das, P., Kumar, S., Mandal, S. C., Prusty, A K., Singh, S. K., Akhtar, M. S., Behera, B. K., Kumar, K., Pal, A. K. and Mukherjee, S. C. (2013) Beta-glucan: an ideal immunostimulant in aquaculture (a review). Fish physiology and biochemistry, 39(3), pp. 431-57. doi: 10.1007/s10695-012-9710-5. 
Mendes-Pinto, M. M. (2009) Carotenoid breakdown products the-norisoprenoids - in wine aroma. Archives of Biochemistry and Biophysics, 483(2), pp. 236-245. doi:

10.1016/j.abb.2009.01.008.

Michalak, I., Chojnacka, K. and Glavic, P. (2009) The possibilities of the application of feed additives from macroalgae in sustainable mineral animal feeding. American Journal of Applied Sciences, 6(8), pp. 1458-1466. doi: 10.3844/ajassp.2009.1458.1466.

Miyashita, K., Mikami, N. and Hosokawa, M. (2013) Chemical and nutritional characteristics of brown seaweed lipids: A review. Journal of Functional Foods. 5(4), pp. 15071517. doi: 10.1016/j.jff.2013.09.019.

Morand, P. and Merceron, M. (2005) Macroalgal Population and Sustainability. Journal of Coastal Research, 215, pp. 1009-1020. doi: 10.2112/04-700A.1.

Moreda-Piñeiro, J., Moreda-Piñeiro, A., Romarís-Hortas, V., Domínguez-González, R., Alonso-Rodríguez, E., López-Mahía, P., Muniategui-Lorenzo, S., Prada-Rodríguez, D. and Bermejo-Barrera, P. (2012) Trace metals in marine foodstuff: Bioavailability estimation and effect of major food constituents. Food Chemistry, 134(1), pp. 339-345. doi:

10.1016/j.foodchem.2012.02.165.

Moroney, N. C., Wan, A. H. L., Soler-Vila, A., O’Grady, M. N., FitzGerald, R. D., Johnson, M. P. and Kerry, J. P. (2016) 'Influence of green seaweed (Ulva Rigida) supplementation on the quality and shelf-life of Atlantic salmon fillets. Journal of Aquatic Food Product Technology. doi: 10.1080/10498850.2015.1046099.

Moroney, N. C., Wan, A. H., Soler-Vila, A., FitzGerald, R. D., Johnson, M. P. and Kerry, J. P. (2015) Inclusion of Palmaria palmata (red seaweed) in Atlantic salmon diets: effects on the quality, shelf-life parameters and sensory properties of fresh and cooked salmon fillets. Journal of the Science of Food and Agriculture, 95(5), pp. 897-905. doi: 10.1002/jsfa.6753.

Morshedi, V., Nafisi Bahabadi, M., Sotoudeh, E., Azodi, M. and Hafezieh, M. (2017) Nutritional evaluation of Gracilaria pulvinata as partial substitute with fish meal in practical diets of barramundi (Lates calcarifer), Journal of Applied Phycology. Journal of Applied Phycology, pp. 110. doi: 10.1007/s10811-017-1199-y.

Mountfort, D. O., Campbell, J. and Clements, K. D. (2002) Hindgut fermentation in three species of marine herbivorous fish. Applied and Environmental Microbiology, 68(3), pp. 13741380. doi: 10.1128/AEM.68.3.1374-1380.2002. 
Munda, I. M. and Veber, M. (2004) Interactive effects of macronutrients and metals (Mn, $\mathrm{Co}, \mathrm{Zn}$ ) on the ephemeral green alga Ulva rigida $\mathrm{C}$. Agardh (Chlorophyta, Ulvophyceae, Ulvales). Nova Hedwigia, 79(3), pp. 353-375. doi: 10.1127/0029-5035/2004/0079-0353.

Nakagawa, H., Kasahara, S., Sugiyama, T. and Wada, I. (1984) Usefulness of ulva-meal as feed supplementary in cultured black sea bream. Aquaculture, 1, pp. 20-26. doi: http://dx.doi.org/10.1016/0044-8486(87)90315-2.

Naylor, R. L., Hardy, R. W., Bureau, D. P., Chiu, A., Elliott, M., Farrell, A. P., Forster, I., Gatlin, D. M., Goldburg, R. J., Hua, K. and Nichols, P. D. (2009) Feeding aquaculture in an era of finite resources. Proceedings of the National Academy of Sciences of the United States of America, 106(36), pp. 15103-10. doi: 10.1073/pnas.0905235106.

Niamnuy, C., Devahastin, S., Soponronnarit, S. and Vijaya Raghavan, G. S. (2008) Kinetics of astaxanthin degradation and color changes of dried shrimp during storage. Journal of Food Engineering, 87(4), pp. 591-600. doi: 10.1016/j.jfoodeng.2008.01.013.

Niwa, K., Furuita, H. and Yamamoto, T. (2008) Changes of growth characteristics and free amino acid content of cultivated Porphyra yezoensis Ueda (Bangiales Rhodophyta) blades with the progression of the number of harvests in a nori farm. Journal of Applied Phycology, 20(5), pp. 687693. doi: 10.1007/s10811-007-9273-5.

Nomura, M., Kamogawa, H., Susanto, E., Kawagoe, C., Yasui, H., Saga, N., Hosokawa, M. and Miyashita, K. (2012) Seasonal variations of total lipids, fatty acid composition, and fucoxanthin contents of Sargassum horneri (Turner) and Cystoseira hakodatensis (Yendo) from the northern seashore of Japan. Journal of Applied Phycology, 25(4), pp. 1159-1169. doi: 10.1007/s10811-0129934-x.

O’Sullivan, L., Murphy, B., McLoughlin, P., Duggan, P., Lawlor, P. G., Hughes, H. and Gardiner, G. E. (2010) Prebiotics from marine macroalgae for human and animal health applications. Marine drugs, 8(7), pp. 2038-64. doi: 10.3390/md8072038.

Oladokun, O. S., Wan-Nik, W. B. and Kader, A. S. A. (2013) Study of properties of components for offshore aquaculture technology farming. Journal of Science and Engineering, 1(2), pp. 155-161.

Oliva-Teles, A., Enes, P. and Peres, H. (2015) Replacing fishmeal and fish oil in industrial aquafeeds for carnivorous fish. In Davies, D. A. (ed.) Feed and feeding practices in aquaculture. Woodhead Publishing, pp. 208-223. 
Oliveira, A. S., Sudatti, D. B., Fujii, M. T., Rodrigues, S. V. and Pereira, R. C. (2013) Interand intrapopulation variation in the defensive chemistry of the red seaweed Laurencia dendroidea (Ceramiales, Rhodophyta). Phycologia, 52(2), pp. 130-136. doi: 10.2216/12-058.1.

Ortiz, J., Romero, N., Robert, P., Araya, J., Lopez-Hernández, J., Bozzo, C., Navarrete, E., Osorio, A. and Rios, A. (2006) Dietary fiber, amino acid, fatty acid and tocopherol contents of the edible seaweeds Ulva lactuca and Durvillaea antarctica. Food Chemistry, 99(1), pp. 98-104. doi: 10.1016/j.foodchem.2005.07.027.

Park, H., Flores, R. A. and Johnson, L. A. (1997) Preparation of fish feed ingredients: reduction of carotenoids in corn gluten meal. Journal of Agricultural and Food Chemistry, 45(6), pp. 2088-2092. doi: 10.1021/jf960972j.

Paul, N. A., Nys, R. De and Steinberg, P. D. (2006) Chemical defence against bacteria in the red alga Asparagopsis armata: linking structure with function. Marine Ecology Progress Series 306, pp. 87-101.

Percival, E. (1979) The polysaccharides of green, red and brown seaweeds: Their basic structure, biosynthesis and function', British Phycological Journal, 14(2), pp. 103-117. doi: $10.1080 / 00071617900650121$.

Peteiro, C., Sánchez, N., Dueñas-Liaño, C. and Martínez, B. (2013) Open-sea cultivation by transplanting young fronds of the kelp Saccharina latissima. Journal of Applied Phycology. doi: 10.1007/s10811-013-0096-2.

Pham, M. A., Lee, K., Lee, B., Lim, S., Kim, S., Lee, Y., Heo, M. and Lee, K. (2006) Effects of dietary Hizikia fusiformis on growth and immune responses in juvenile olive flounder (Paralichthys olivaceus). 19(12), pp. 1769-1775.

Pinto, E., Sigaud-kutner, T. C. S., Leitao, M. A. S., Okamoto, O. K., Morse, D. and Colepicolo, P. (2003) Heavy metal-induced oxidative stress in algae. Journal of Phycology, 39(6), pp. 1008-1018. doi: 10.1111/j.0022-3646.2003.02-193.x.

Prabu, D. L., Sahu, N. P., Pal, A. K., Dasgupta, S. and Narendra, A. (2016) Immunomodulation and interferon gamma gene expression in sutchi cat fish, Pangasianodon hypophthalmus: Effect of dietary fucoidan rich seaweed extract (FRSE) on pre and post challenge period. Aquaculture Research, 47(1), pp. 199-218. doi: 10.1111/are.12482.

Rae, M., Folch, H., Moniz, M. B. J., Wolff, C. W., McCormack, G. P., Rindi, F. and Johnson, M. P. (2012) Marine bioactivity in Irish waters. Phytochemistry Reviews. doi: $10.1007 / \mathrm{s} 11101-012-9227-7$. 
Ragaza, J. A., Koshio, S., Mamauag, R. E., Ishikawa, M., Yokoyama, S. and Villamor, S. S. (2013) 'Dietary supplemental effects of red seaweed Eucheuma denticulatum on growth performance, carcass composition and blood chemistry of juvenile Japanese flounder, Paralichthys olivaceus. Aquaculture Research, (Burtin 2003), p. n/a-n/a. doi: 10.1111/are.12211.

Ragaza, J. A., Koshio, S., Mamauag, R. E., Ishikawa, M., Yokoyama, S. and Villamor, S. S. (2015) Dietary supplemental effects of red seaweed Eucheuma denticulatum on growth performance, carcass composition and blood chemistry of juvenile Japanese flounder, Paralichthys olivaceus. Aquaculture Research, 46(3), pp. 647-657. doi: 10.1111/are.12211.

Rama Nisha, P., Elezabeth Mary, A., Uthayasiva, M. and Arularasan, S. (2014) Seaweed Ulva reticulata a potential feed supplement for growth, colouration and disease resistance in fresh water ornamental gold fish, Carassius auratus. Journal of Aquaculture Research \& Development, 5(5). doi: 10.4172/2155-9546.1000254.

Ramnani, P., Chitarrari, R., Tuohy, K., Grant, J., Hotchkiss, S., Philp, K., Campbell, R., Gill, C. and Rowland, I. (2012) In vitro fermentation and prebiotic potential of novel low molecular weight polysaccharides derived from agar and alginate seaweeds. Anaerobe. Elsevier Ltd, 18(1), pp. 1-6. doi: 10.1016/j.anaerobe.2011.08.003.

Ratcliff, J. J., Wan, A. H. L., Edwards, M. D., Soler-Vila, A., Johnson, M. P., Abreu, M. H. and Morrison, L. (2016) 'Metal content of kelp (Laminaria digitata) co-cultivated with Atlantic salmon in an Integrated Multi-Trophic Aquaculture system. Aquaculture. Elsevier B.V., 450, pp. 234-243. doi: 10.1016/j.aquaculture.2015.07.032.

Rathmann, R., Szklo, A. and Schaeffer, R. (2010) Land use competition for production of food and liquid biofuels: An analysis of the arguments in the current debate. Renewable Energy, 35(1), pp. 14-22. doi: 10.1016/j.renene.2009.02.025.

Ratti, C. (2001) Hot air and freeze-drying of high-value foods: a review. Journal of Food Engineering, 49(4), pp. 311-319. doi: 10.1016/S0260-8774(00)00228-4.

Refstie, S., Sahlström, S., Bråthen, E., Baeverfjord, G. and Krogedal, P. (2005) Lactic acid fermentation eliminates indigestible carbohydrates and antinutritional factors in soybean meal for Atlantic salmon (Salmo salar). Aquaculture, 246(1-4), pp. 331-345. doi: 10.1016/j.aquaculture.2005.01.001.

Ringø, E. and Gatesoupe, F. J. (1998) Lactic acid bacteria in fish: A review. Aquaculture, 160(3-4), pp. 177-203. doi: 10.1016/S0044-8486(97)00299-8. 
Ringo, E., Olsen, R. E., Gifstad, T. Ø., Dalmo, R. A., Amlund, H., Hemre, G.-I. and Bakke, A. M. (2010) Prebiotics in aquaculture: a review. Aquaculture Nutrition, 16(2), pp. 117-136. doi: 10.1111/j.1365-2095.2009.00731.x.

Robinson, N., Winberg, P. and Kirkendale, L. (2013) Genetic improvement of macroalgae: status to date and needs for the future. pp. 703-716. doi: 10.1007/s10811-012-9950-x.

Rose, M., Lewis, J., Langford, N., Baxter, M., Origgi, S., Barber, M., MacBain, H. and Thomas, K. (2007) Arsenic in seaweed-forms, concentration and dietary exposure. Food and chemical toxicology, 45(7), pp. 1263-7. doi: 10.1016/j.fct.2007.01.007.

Roy, M.-C., Anguenot, R., Fillion, C., Beaulieu, M., Bérubé, J. and Richard, D. (2011) Effect of a commercially-available algal phlorotannins extract on digestive enzymes and carbohydrate absorption in vivo, Food Research International. Elsevier Ltd, 44(9), pp. 3026-3029. doi: 10.1016/j.foodres.2011.07.023.

Ruperez, P. (2002) Mineral content of edible marine seaweeds. Food Chemistry, 79(1), pp. 23-26. doi: 10.1016/S0308-8146(02)00171-1.

Ruxton, C. H. S., Reed, S. C., Simpson, M. J. A and Millington, K. J. (2004) The health benefits of omega-3 polyunsaturated fatty acids: a review of the evidence. Journal of human nutrition and dietetics, 17(5), pp. 449-59. doi: 10.1111/j.1365-277X.2004.00552.x.

Ryan, S., McLoughlin, P. and O’Donovan, O. (2012) A comprehensive study of metal distribution in three main classes of seaweed. Environmental pollution. Elsevier Ltd, 167, pp. 1717. doi: 10.1016/j.envpol.2012.04.006.

Sagar, V. R. and Suresh Kumar, P. (2010) Recent advances in drying and dehydration of fruits and vegetables: a review. Journal of food science and technology, 47(1), pp. 15-26. doi: 10.1007/s13197-010-0010-8.

Samarakoon, K. and Jeon, Y. J. (2012) Bio-functionalities of proteins derived from marine algae - A review., Food Research International 48(2), pp. 948-960. doi: 10.1016/j.foodres.2012.03.013.

Sarada, R. A. R., Baskaran, V. and Ravishankar, G. A. (2009) Identification of carotenoids from green alga Haelnalococclis pilivialis by HPLC and LC-MS (APel) and their antioxidant properties. 19(August), pp. 1333-1341. doi: 10.4014/jmb.0905.03007.

Seeley, R. H. and Schlesinger, W. H. (2012) Sustainable seaweed cutting? The rockweed (Ascophyllum nodosum) industry of Maine and the Maritime Provinces. Annals of the New York Academy of Sciences, 1249, pp. 84-103. doi: 10.1111/j.1749-6632.2012.06443.x. 
SEI (2009) A Review of the Potential of Marine Algae as a Source of Biofuel in Ireland. Available at:

http://www.seai.ie/Publications/Renewables_Publications_/Bioenergy/Algaereport.pdf.

Sekar, S. and Chandramohan, M. (2007) Phycobiliproteins as a commodity: trends in applied research, patents and commercialization. Journal of Applied Phycology, 20(2), pp. 113136. doi: 10.1007/s10811-007-9188-1.

Shepherd, C. J. and Jackson, A. J. (2013) Global fishmeal and fish-oil supply: inputs, outputs and markets. Journal of Fish Biology, 83(4) pp. 1046-1066. doi: 10.1111/jfb.12224.

Shpigel, M., Guttman, L., Shauli, L., Odintsov, V., Harpaz, S. and Ben-Ezra, D. (2017) Ulva lactuca from an Integrated Multi-Trophic Aquaculture (IMTA) biofilter system as a protein supplement in gilthead seabream (Sparus aurata) diet. Aquaculture, 481, pp. 112-118. doi: 10.1016/j.aquaculture.2017.08.006.

Shobharani, P., Halami, P. M. and Sachindra, N. M. (2013) Potential of marine lactic acid bacteria to ferment Sargassum sp. for enhanced anticoagulant and antioxidant properties. Journal of applied microbiology, 114(1), pp. 96-107. doi: 10.1111/jam.12023.

Silva, D. M., Valente, L. M. P., Sousa-Pinto, I., Pereira, R., Pires, M. A., Seixas, F. and Rema, P. (2014) Evaluation of IMTA-produced seaweeds (Gracilaria, Porphyra, and Ulva) as dietary ingredients in Nile tilapia, Oreochromis niloticus L., juveniles. Effects on growth performance and gut histology. Journal of Applied Phycology. doi: 10.1007/s10811-014-0453-9.

Sinha, A. K., Kumar, V., Makkar, H. P. S., De Boeck, G. and Becker, K. (2011) Non-starch polysaccharides and their role in fish nutrition - A review. Food Chemistry. Elsevier Ltd, 127(4), pp. 1409-1426. doi: 10.1016/j.foodchem.2011.02.042.

Sloth, J. J., Julshamn, K. and Lundebye, A.-K. (2005) Total arsenic and inorganic arsenic content in Norwegian fish feed products. Aquaculture Nutrition, 11(1), pp. 61-66. doi: 10.1111/j.1365-2095.2004.00334.x.

Soler-Vila, A., Coughlan, S., Guiry, M. D. and Kraan, S. (2009) The red alga Porphyra dioica as a fish-feed ingredient for rainbow trout (Oncorhynchus mykiss): effects on growth, feed efficiency, and carcass composition. Journal of Applied Phycology, 21(5), pp. 617-624. doi: 10.1007/s10811-009-9423-z.

Sotoudeh, E. and Jafari, M. (2017) Effects of dietary supplementation with red seaweed, Gracilaria pygmaea, on growth, carcass composition and hematology of juvenile rainbow trout, Oncorhynchus mykiss. Aquaculture International. Aquaculture International, 25(5), pp. 1857-1867. doi: 10.1007/s10499-017-0158-6. 
Steinberg, D. P. (1989) Biogeographical Variation in Brown Algal Polyphenolics and Other Secondary Metabolites: Comparison between Temperate Australasia and North America.

Oecologia, 78(3), pp. 373-382.

Svensson, J. R., Nylund, G. M., Cervin, G., Toth, G. B. and Pavia, H. (2013) Novel chemical weapon of an exotic macroalga inhibits recruitment of native competitors in the invaded range. Journal of Ecology, 101(1), pp. 140-148. doi: 10.1111/1365-2745.12028.

Taylor, V., Goodale, B.,Raab, A., Schwerdtle, T., Reimer, K., Conklin, S., Karagas, M. R., Francesconi, K. A., (2017) Human exposure to organic arsenic species from seafood. Science of the Total Environment 580, pp. 266-282. doi:10.1016/j.scitotenv.2016.12.113

Thi, N., Anh, N., Nevejan, N. and Bossier, P. (2015) Seaweed, Enteromorpha intestinalis, as a diet for nile tilapia Oreochromis niloticus fry. Journal of Applied Aquaculture, 27(2), pp. 113123. doi: 10.1080/10454438.2015.1008286.

Thompson, S., Knoll, H., Blanchette, C. and Nielsen, K. (2010) Population consequences of biomass loss due to commercial collection of the wild seaweed Postelsia palmaeformis. Marine Ecology Progress Series, 413, pp. 17-32. doi: 10.3354/meps08705.

Tierney, M. S., Croft, A. K. and Hayes, M. (2010) A review of antihypertensive and antioxidant activities in macroalgae. Botanica Marina, 53(5), pp. 387-408. doi:

10.1515/bot.2010.044.

Todorcević, M., Kjaer, M. a, Djaković, N., Vegusdal, A., Torstensen, B. E. and Ruyter, B. (2009) n-3 HUFAs affect fat deposition, susceptibility to oxidative stress, and apoptosis in Atlantic salmon visceral adipose tissue. Comparative biochemistry and physiology. Part B, Biochemistry \& molecular biology. 52(2), pp. 135-43. doi: 10.1016/j.cbpb.2008.10.009.

Torrissen, O. J. and Christiansen, R. (1995) Requirements for carotenoids in fish diets. Journal of Applied Ichthyology, 11(3-4), pp. 225-230. doi: 10.1111/j.1439-0426.1995.tb00022.x.

Troell, M., Joyce, A., Chopin, T., Neori, A., Buschmann, A. H. and Fang, J.-G. (2009) Ecological engineering in aquaculture - Potential for integrated multi-trophic aquaculture (IMTA) in marine offshore systems. Aquaculture. 297(1-4), pp. 1-9. doi:

10.1016/j.aquaculture.2009.09.010.

Tucker, C. S. (2000) Off-flavor problems in aquaculture. Reviews in Fisheries Science, 8(1), pp. 45-88. doi: 10.1080/10641260091129170.

Valente, L. M. P., Araújo, M., Batista, S., Peixoto, M. J., Sousa-Pinto, I., Brotas, V., Cunha, L. M. and Rema, P. (2015) Carotenoid deposition, flesh quality and immunological response of Nile 
tilapia fed increasing levels of IMTA-cultivated Ulva spp. Journal of Applied Phycology. doi: 10.1007/s10811-015-0590-9.

Valente, L. M. P., Rema, P., Ferraro, V., Pintado, M., Sousa-Pinto, I., Cunha, L. M., Oliveira, M. B. and Araújo, M. (2015) Iodine enrichment of rainbow trout flesh by dietary supplementation with the red seaweed Gracilaria vermiculophylla. Aquaculture. 446, pp. 132-139. doi: 10.1016/j.aquaculture.2015.05.004.

Vásquez, J. A. (2008) Production, use and fate of Chilean brown seaweeds: re-sources for a sustainable fishery. Journal of Applied Phycology, 20(5), pp. 457-467. doi: 10.1007/s10811-0079308-y.

Vauchel, P., Kaas, R., Arhaliass, A., Baron, R. and Legrand, J. (2008) A new process for the extraction of alginates from Laminaria digitata: reactive extrusion. Food and Bioprocess Technology, 1(3), pp. 297-300. doi: 10.1007/s11947-008-0082-x.

Vea, J. and Ask, E. (2010) Creating a sustainable commercial harvest of Laminaria hyperborea, in Norway. Journal of Applied Phycology, 23(3), pp. 489-494. doi: 10.1007/s10811010-9610-y.

Wahbeh, M. (1997) Amino acid and fatty acid profiles of four species of macroalgae from Aqaba and their suitability for use in fish diets. Aquaculture, 159, pp. 101-109. doi: /10.1016/S0044-8486(97)00183-X.

Walters, L. (2009) Ecology and management of the invasive marine macroalga Caulerpa taxifolia. Management of Invasive Weeds, pp. 287-318. doi: 10.1007/978-1-4020-9202-2_15.

Wan, A. H. L., Soler-Vila, A., O’Keeffe, D., Casburn, P., Fitzgerald, R. and Johnson, M. P. (2016) 'The inclusion of Palmaria palmata macroalgae in Atlantic salmon (Salmo salar) diets: effects on growth, haematology, immunity and liver function. Journal of Applied Phycology. doi: 10.1007/s10811-016-0821-8.

Wang, Y., Zhou, B. and Tang, X. (2008) Effects of two species of macroalgae-Ulva pertusa and Gracilaria lemaneiformis on growth of Heterosigma akashiwo (Raphidophyceae)', Journal of Applied Phycology, 21(4), pp. 375-385. doi: 10.1007/s10811-008-9380-y.

Wassef, E. A., El-Sayed, A.-F. M. and Sakr, E. M. (2013) Pterocladia (Rhodophyta) and Ulva (Chlorophyta) as feed supplements for European seabass, Dicentrarchus labrax L., fry. Journal of Applied Phycology, 25(5), pp. 1369-1376. doi: 10.1007/s10811-013-9995-5.

Watanabe, T., Kiron, V. and Satoh, S. (1997) Trace minerals in fish nutrition. Aquaculture, 151(1-4), pp. 185-207. doi: 10.1016/S0044-8486(96)01503-7. 
Wilson, R. P. (1994) Utilization of dietary carbohydrate by fish. Aquaculture, 124(1-4), pp. 67-80. doi: 10.1016/0044-8486(94)90363-8.

Wu, S., Wang, F. and Pan, C. (2007) Growth and survival of lactic acid bacteria during the fermentation and storage of seaweed oligosaccharides solution. Journal of Marine Science and Technology, 15(2), pp. 104-114. Available at: http://jmst.ntou.edu.tw/marine/15-2/104-114.pdf (Accessed: 14 October 2012).

Xu, S., Zhang, L., Wu, Q., Liu, X., Wang, S., You, C. and Li, Y. (2011) Evaluation of dried seaweed Gracilaria lemaneiformis as an ingredient in diets for teleost fish Siganus canaliculatus. Aquaculture International, 19(5), pp. 1007-1018. doi: 10.1007/s10499-011-9418-z.

Xu, X., Song, F., Fan, X., Fang, N. and Shi, J. (2010) A novel bromophenol from marine red alga Symphyocladia latiuscula. Chemistry of Natural Compounds, 45(6), pp. 811-813. doi: 10.1007/s10600-010-9501-0.

Xuan, X., Wen, X., Li, S., Zhu, D. and Li, Y. (2013) Potential use of macro-algae Gracilaria lemaneiformis in diets for the black sea bream, Acanthopagrus schlegelii, juvenile. Aquaculture. 412-413, pp. 167-172. doi: 10.1016/j.aquaculture.2013.07.022.

Yan, X., Zheng, L., Chen, H., Lin, W. and Zhang, W. (2004) Enriched accumulation and biotransformation of selenium in the edible seaweed Laminaria japonica. Journal of Agricultural and Food Chemistry, 52(21), pp. 6460-4. doi: 10.1021/jf040195k.

Yarnpakdee, S., Benjakul, S., Penjamras, P. and Kristinsson, H. G. (2014) Chemical compositions and muddy flavour/odour of protein hydrolysate from Nile tilapia and broadhead catfish mince and protein isolate. Food Chemistry, 142, pp. 210-216. doi:

10.1016/j.foodchem.2013.07.043.

Ye, C. L., Anderson, D. M. and Lall, S. P. (2016) The effects of camelina oil and solvent extracted camelina meal on the growth, carcass composition and hindgut histology of Atlantic salmon (Salmo salar) parr in freshwater. Aquaculture, 450, pp. 397-404. doi:

10.1016/j.aquaculture.2015.08.019.

Yone, Y., Furuichi, M. and Urano, K. (1986) Effects of dietary wakame Undaria penatifida and Ascophyllum nodosum supplements on growth, feed efficiency, and proximate compositions of liver and muscle. Nippon Suisan Gakkaishi, 52(8), pp. 1465-1468.

Zemke-White, W., Bremner, G. and Hurd, C. (1999) The status of commercial algal utilization in New Zealand. Sixteenth International Seaweed symposium, 137, pp. 487-494. doi: 10.1007/978-94-011-4449-0_59. 
Zhang, J., Huo, Y., Wu, H., Yu, K., Kim, J. K., Yarish, C., Qin, Y., Liu, C., Xu, R. and He, P. (2014) The origin of the Ulva macroalgal blooms in the Yellow Sea in 2013. Marine Pollution Bulletin, 89(1-2), pp. 276-283. doi: 10.1016/j.marpolbul.2014.09.049.

Zhang, S., Hu, X., Ma, J., Ma, Z., Liu, X. and Cui, L. (2012) Study on feed fermented from seaweed waste. African Journal of Microbiology Research, 6(50), pp. 7610-7615. doi: 10.5897/AJMR12.2439.

Zhao, J. and Cheung, P. C. K. (2011) Fermentation of $\beta$-glucans derived from different sources by bifidobacteria: Evaluation of their bifidogenic effect. pp. 5986-5992.

Zia-ur-Rehman and Salariya, A. M. (2005) The effects of hydrothermal processing on antinutrients, protein and starch digestibility of food legumes. International Journal of Food Science and Technology, 40(7), pp. 695-700. doi: 10.1111/j.1365-2621.2005.00978.x. 
Table 1: Proximate composition of economically important seaweeds.

\begin{tabular}{|c|c|c|c|c|c|c|}
\hline & Moisture & Protein* & Lipid $^{*}$ & Fibre* $^{*}$ & $\mathrm{Ash}^{*}$ & Ref \\
\hline \multicolumn{7}{|l|}{ Chlorophyta } \\
\hline Caulerpa lentillifera & 94.0 & 9.7 & 7.2 & - & 46.4 & (McDermid and Stuercke, 2003) \\
\hline Ulva (Enteromorpha) clathrata & - & $19.2-23.4$ & 1.0 & 4.6 & 16.0 & (Peña-Rodríguez et al., 2011) \\
\hline Ulva compressa & 83.1 & 26.6 & - & 41.2 & - & (Patarra et al., 2010) \\
\hline Ulva fasciata & 83.4-86.1 & 8.8-12.3 & $3.6-5.1$ & - & 25.4-32.2 & (McDermid and Stuercke, 2003) \\
\hline Ulva (Enteromorpha) intestinalis & - & 6.15 & 7.13 & - & - & (Chakraborty and Santra, 2008) \\
\hline Ulva lactuca & 79.6 & $8.5-17.44$ & $2.5-7.9$ & $2.8-54.0$ & $19.6-32.9$ & $\begin{array}{l}\text { (Marsham et al., 2007; Yaich et al., 2011; Yildirim et } \\
\text { al., 2009) }\end{array}$ \\
\hline Ulva (Enteromorpha) linza & - & 14.1 & 2.2 & 33.1 & 32.6 & (Yildirim et al., 2009) \\
\hline Ulva reticulata & - & 21.06 & 0.8 & 55.8 & 17.6 & (Ratana-arporn and Chirapart, 2006) \\
\hline Ulva (Enteromorpha) prolifera & 80.9 & 10.9 & 3.2 & 5.2 & 14.3 & (Asino et al., 2011) \\
\hline \multicolumn{7}{|l|}{ Rhodophyta } \\
\hline Palmaria palmata & - & 12.3 & - & 45.3 & 15.5 & (Marrion et al., 2005) \\
\hline Eucheuma denticulatum & 89.9 & 4.9 & 2.2 & - & 43.6 & (McDermid and Stuercke, 2003) \\
\hline Chondrus crispus & & 20.1-20.9 & & 34.3 & 21.4 & (Rupérez and Saura-Calixto, 2001) \\
\hline Mastocarpus stellatus & 64.9 & 25.4 & 3.0 & 1.8 & 15.6 & (Marsham et al., 2007) \\
\hline Pyropia spp. & 79.9 & $25.8-26.6$ & 2.1 & $41.0-45.6$ & 21.0 & (Dawczynski et al., 2007; Patarra et al., 2010) \\
\hline Gracilaria lemaneiformis & - & 19.1 & 0.5 & - & 19.7 & (Xuan et al., 2013) \\
\hline Gracilaria spp. & 90.4 & $5.6-24.0$ & - & 30.5 & $15.2-23.6$ & (Marrion et al., 2005) \\
\hline Gracilaria changgi & - & 6.9 & 3.3 & 24.7 & 22.7 & (Norziah and Ching, 2000) \\
\hline Gelidium microdon & 71.4 & 15.2 & - & 57.4 & - & (Patarra et al., 2010) \\
\hline \multicolumn{7}{|l|}{ Phaeophyceae } \\
\hline Alaria esculenta & 82.6 & 9.1 & $1.3-1.5$ & - & 24.6 & (Maehre et al., 2014) \\
\hline Ascophyllum nodosum & - & $6.8-7.9$ & 2.7 & 3.5 & 21.2 & (Cruz-Suárez et al., 2009) \\
\hline Hizikia fusiformis & - & $11.6-13.9$ & $0.4-2.4$ & $43.8-59.0$ & 26.6 & (Dawczynski et al., 2007; Jang et al., 2012) \\
\hline Laminaria digitata & 86.1 & 15.9 & 0.5 & 7.7 & 23.6 & (Marsham et al., 2007) \\
\hline Laminaria hyperborea & 83.3 & $11.4-14.2$ & 5.0 & - & 28.8 & (Maehre et al., 2014) \\
\hline Macrocystis pyrifera & - & $5.3-6.1$ & 0.7 & 10.5 & 31.1 & (Cruz-Suárez et al., 2009) \\
\hline Laminaria (Saccharina) japonica & - & 10.6 & 1.6 & 66.0 & 21.6 & (Jang et al., 2012) \\
\hline Saccharina latissima & - & 14.2 & 0.1 & 36.4 & 9.7 & (Jard et al., 2012) \\
\hline Undaria pinnatifida & - & $18.3-19.8$ & $1.8-4.5$ & $45.9-52.0$ & 28.0 & (Dawczynski et al., 2007; Jang et al., 2012) \\
\hline
\end{tabular}

\footnotetext{
*dry weight.
} 
Table 2: Macroalgae polysaccharides, their commercial uses and biological activities.

\begin{tabular}{lllll}
\hline Seaweed & Example species & Sugar monomers & Biological activity \& commercial value & \\
\hline Chlorophyta & & & & \\
\hline Ulvan & Ulva & sulfates, rhamnose, xylose, & Anti-tumour, anti-oxidant, anti-thrombolytic immunal \\
& & iduronic \& glucuronic acid & $\begin{array}{l}\text { modulation, anti-influenza, and anti-coagulant } \\
\text { (Lahaye and Robic, }\end{array}$
\end{tabular}

Iduronic acid could be used in heparin synthesis. Desulfated ulvan is patented for its ability to induce mucin production to treat gastric ulcers

\begin{tabular}{|c|c|c|c|c|}
\hline \multicolumn{5}{|l|}{ Rhodophyta } \\
\hline Carrageenan & $\begin{array}{l}\text { Chondrus crispus, } \\
\text { Euchema, } \\
\text { Kappaphycus }\end{array}$ & $\begin{array}{l}\text { D-galactose and 3,6- } \\
\text { anhydro-galactose }(3,6-A G)\end{array}$ & $\begin{array}{l}\text { Anti-coagulant, platelet aggregation inhibition, anti-viral, anti- } \\
\text { tumor activity. I and K-carrageenan show enhancement in } \\
\text { immunal parameters }\end{array}$ & $\begin{array}{l}\text { (Cheng et al., 2008; } \\
\text { Prajapati et al., } \\
\text { 2014) }\end{array}$ \\
\hline Porphyran & Pyropia & $\begin{array}{l}\beta \text {-D-galactosyl and } \alpha-I- \\
\text { galactosyl 6- sulfate or 3,6- } \\
\text { anhydro- } \alpha-L-\text { galactosyl }\end{array}$ & $\begin{array}{l}\text { Degraded and untreated porphyran possesses scavenging } \\
\text { free radical activity and functions reducing power. Can induce } \\
\text { murine macrophage phagocytic activity. }\end{array}$ & $\begin{array}{l}\text { (Yoshizawa et al., } \\
\text { 1995; Zhao et al., } \\
\text { 2006) }\end{array}$ \\
\hline Agar & $\begin{array}{l}\text { Gracilaria, } \\
\text { Gelidium }\end{array}$ & $\begin{array}{l}\text { D-galactose and 3,6 } \\
\text { anhydro L-galactose }\end{array}$ & Extracted for gelling and stabilising capabilities. & $\begin{array}{l}\text { (Ramnani et al., } \\
\text { 2012) }\end{array}$ \\
\hline \multicolumn{5}{|c|}{ Phaeophyceae } \\
\hline Laminarin & $\begin{array}{l}\text { Laminaria, } \\
\text { Saccharina, } \\
\text { Fucus }\end{array}$ & $\begin{array}{l}\beta(1 \rightarrow 3) \text {-glucan } \& \beta(1 \rightarrow 6) \\
\text { glucan }\end{array}$ & $\begin{array}{l}\text { Anti-tumour, anti-inflammatory, immune-stimulatory, anti- } \\
\text { coagulant and anti-oxidant activity }\end{array}$ & $\begin{array}{l}\text { (Kadam et al., 2015; } \\
\text { Rioux et al., 2010). }\end{array}$ \\
\hline Alginate & $\begin{array}{l}\text { Ascophyllum } \\
\text { nodosum, } \\
\text { Laminaria, } \\
\text { Macrocystis }\end{array}$ & $\begin{array}{l}\alpha-L-\text { guluronic } \\
\text { acid and } \beta \text {-L-mannuronic } \\
\text { acid }\end{array}$ & Commercial alginate salts have immunal modulation properties & $\begin{array}{l}\text { (Caipang et al., } \\
\text { 2011; Cheng et al., } \\
\text { 2008) }\end{array}$ \\
\hline Fucoidan & $\begin{array}{l}\text { Fucus, } \\
\text { Saccharina, } \\
\text { Laminaria, } \\
\text { Sargassum }\end{array}$ & $\begin{array}{l}(1 \rightarrow 3) \text { a-l-fucopyranosyl, } \\
(1 \rightarrow 4) \text { a-l-fucopyranosyl, } \\
\text { sulphated sugar groups, } \\
\text { fucose, fuco- } \\
\text { oligosaccharide, uronic } \\
\text { acid, xylose, manose } \\
\text { galactose, glucose. }\end{array}$ & $\begin{array}{l}\text { Anti-viral, anti-tumour, immune-stimulatory, anti-oxidant, anti- } \\
\text { inflammatory, anti-coagulant and anti-thrombotic activity. Ability } \\
\text { to reduce cholesterol, triglyceride and LDL-C, and increase } \\
\text { HDL-C. Gastric protection (e.g. antiulcer, anti-adhesion for } \\
\text { Helicobacter pyroli), protection against urinary tract, kidney and } \\
\text { liver diseases }\end{array}$ & $\begin{array}{l}\text { (Caipang et al., } \\
\text { 2011; Li et al., 2008) }\end{array}$ \\
\hline
\end{tabular}


Table 3: The effects of dietary macroalgae inclusion has on farmed finfish growth performance.

\begin{tabular}{|c|c|c|c|c|c|c|}
\hline Algae & Fish & $\begin{array}{c}\text { Natural } \\
\text { diet }^{\mathrm{a}}\end{array}$ & $\begin{array}{c}\text { Inclusion } \\
(\%)\end{array}$ & $\begin{array}{l}\text { Duration } \\
\text { (weeks) }\end{array}$ & Growth effect & Reference \\
\hline \multicolumn{7}{|l|}{ Chlorophyta } \\
\hline $\begin{array}{l}\text { Ulva } \\
\text { (Enteromorpha) } \\
\text { intestinalis }\end{array}$ & $\begin{array}{l}\text { Nile tilapia } \\
\text { (fry) }\end{array}$ & $\mathrm{H}$ & $\begin{array}{l}10,20,30 \\
\quad 40,50\end{array}$ & 6 & $\begin{array}{l}\downarrow F W, \text { WG, SGR, \& Total FI when inclusion } \uparrow \\
\leftrightarrow \text { Feed consumption, FCR, \& PER }\end{array}$ & $\begin{array}{l}\text { (Thi et al., } \\
\text { 2015) }\end{array}$ \\
\hline $\begin{array}{l}\text { Ulva intestinalis } \\
\text { (Protein } \\
\text { concentrate) }\end{array}$ & $\begin{array}{l}\text { Nile tilapia } \\
\text { (fry) }\end{array}$ & $\mathrm{H}$ & $\begin{array}{c}3.9,7.8 \\
11.7\end{array}$ & $\begin{array}{c}12.9 \\
\text { (90 days) }\end{array}$ & $\begin{array}{l}\downarrow \text { WG, SGR, \& FI at } 7.8 \& 11.7 \% \\
\downarrow \text { FI at } 3.9 \% \\
\leftrightarrow \text { WG \& SGR at } 3.9 \% \\
\leftrightarrow \text { FCR \& protein retention } \\
\downarrow \text { lipid retention }\end{array}$ & $\begin{array}{l}\text { (Serrano and } \\
\text { Aquino, 2014) }\end{array}$ \\
\hline Ulva lactuca & $\begin{array}{l}\text { Gilthead } \\
\text { seabream }\end{array}$ & $\mathrm{O}$ & $\begin{array}{l}2.6,7.8 \\
(\exp 1) \\
14.6,29.1 \\
(\exp 2)\end{array}$ & $\begin{array}{l}15.9(\exp 1) \\
20.1(\exp 2)\end{array}$ & $\begin{array}{l}\leftrightarrow \text { no change }(\exp 1) \\
\downarrow \text { FW \& SGR at } 29.1 \%(\exp 2) \\
\leftrightarrow \text { FW, SGR, WG at } 15.9 \%(\exp 2)\end{array}$ & $\begin{array}{l}\text { Shpigel et al., } \\
2017\end{array}$ \\
\hline Ulva lactuca & $\begin{array}{l}\text { European } \\
\text { seabass }\end{array}$ & $\mathrm{C}$ & $5,10,15$ & 8 & $\begin{array}{l}\uparrow \mathrm{FW}, \text { WG, protein productive value but } \downarrow \text { when } \% \text { inclusion } \\
\uparrow \mathrm{FCR} \text { when } \% \text { inclusion } \uparrow \\
\leftrightarrow \mathrm{FI} \& \text { PER }\end{array}$ & $\begin{array}{l}\text { (Wassef et al., } \\
2013 \text { ) }\end{array}$ \\
\hline Ulva lactuca & $\begin{array}{l}\text { African } \\
\text { catfish }\end{array}$ & $\mathrm{C} / \mathrm{O}$ & $10,20,30$ & 10 & $\begin{array}{l}\leftrightarrow \mathrm{FW}, \mathrm{BL}, \mathrm{WG}, \mathrm{CF}, \mathrm{SGR}, \mathrm{FCR}, \mathrm{PER} \text { at } 10 \% \text { inclusion } \\
\downarrow \mathrm{FI} \text {, daily feed take\& protein productive values at } 10 \% \\
\text { inclusion } \\
\downarrow \mathrm{FW}, \mathrm{BL}, \mathrm{WG}, \mathrm{CF}, \mathrm{SGR}, \mathrm{FI}, \text { Daily FI, \& PER at } 20 \& 30 \% \\
\text { inclusion } \\
\uparrow \mathrm{FCR} \text { at } 20 \& 30 \% \text { inclusion }\end{array}$ & $\begin{array}{l}\text { (Abdel-warith } \\
\text { et al., 2015) }\end{array}$ \\
\hline Ulva lactuca & $\begin{array}{l}\text { Striped } \\
\text { mullet }\end{array}$ & O/D & $\begin{array}{c}10,15,20 \\
25\end{array}$ & 15 & $\begin{array}{l}\uparrow F W, \text { WG, SGR, Percent WG, PER when } \% \text { inclusion } \uparrow \\
\uparrow \text { WG from } 20 \% \\
\downarrow \text { FCR when } \% \text { inclusion } \uparrow\end{array}$ & $\begin{array}{l}\text { (Wassef et al., } \\
\text { 2001) }\end{array}$ \\
\hline Ulva lactuca & $\begin{array}{l}\text { Rainbow } \\
\text { trout }\end{array}$ & $\mathrm{C}$ & 10 & $\begin{array}{l}8.6(80 \\
\text { days) }\end{array}$ & $\downarrow$ WG, Relative growth rate, \& SGR & $\begin{array}{l}\text { (Yildirim et al., } \\
\text { 2009) }\end{array}$ \\
\hline Ulva linza & $\begin{array}{l}\text { Rainbow } \\
\text { trout }\end{array}$ & $\mathrm{C}$ & 10 & $\begin{array}{c}8.6(80 \\
\text { days })\end{array}$ & $\downarrow$ WG, Relative growth rate, \& SGR & $\begin{array}{l}\text { (Yildirim et al., } \\
\text { 2009) }\end{array}$ \\
\hline Ulva rigida & Nile tilapia & $\mathrm{H}$ & $10,20,30$ & $\begin{array}{c}10.7 \\
\text { (75 days) }\end{array}$ & $\begin{array}{l}\downarrow \text { FW; Relative Growth Rate, daily WG \& PER at } 30 \% \\
\uparrow \text { FCR at } 30 \%\end{array}$ & $\begin{array}{l}\text { (Azaza et al., } \\
2008)\end{array}$ \\
\hline
\end{tabular}




\begin{tabular}{|c|c|c|c|c|c|c|}
\hline Algae & Fish & $\begin{array}{c}\text { Natural } \\
\text { diet }\end{array}$ & $\begin{array}{c}\text { Inclusion } \\
(\%)\end{array}$ & $\begin{array}{l}\text { Duration } \\
\text { (weeks) }\end{array}$ & Growth effect & Reference \\
\hline \multicolumn{7}{|l|}{ Chlorophyta } \\
\hline Ulva rigida & $\begin{array}{l}\text { Common } \\
\text { Carp }\end{array}$ & $\mathrm{O}$ & $\begin{array}{c}5,10,15 \\
20\end{array}$ & 16 & $\begin{array}{l}\leftrightarrow \mathrm{FW}, \mathrm{WG}, \mathrm{FCR}, \mathrm{SGR}, \mathrm{PER} \text { at } 5-15 \% \\
\uparrow \mathrm{FI} \text { at } 5 \%, \mathrm{FCR} \text { at } 20 \%, \& \text { ANEU at } 5-15 \% \\
\downarrow \text { all growth parameters at } 20 \%\end{array}$ & $\begin{array}{l}\text { (Diler et al., } \\
\text { 2007) }\end{array}$ \\
\hline Ulva rigida & Nile tilapia & $\mathrm{H}$ & $\begin{array}{l}\text { Lo lipid } \\
+5 \% \\
\text { Hi Lipid }+ \\
5 \%\end{array}$ & 16 & $\begin{array}{l}\uparrow \text { FW, SGR, PER \& net protein utilisation } \\
\uparrow \text { Net energy utilisation with Hi Ulva } \\
\downarrow \text { FCR }\end{array}$ & $\begin{array}{l}\text { (Ergün et al., } \\
2008 \text { ) }\end{array}$ \\
\hline Ulva rigida & $\begin{array}{l}\text { Gilthead } \\
\text { seabream }\end{array}$ & $\mathrm{O}$ & $\begin{array}{l}5 \text { Ulva }+13 \\
\text { 16, } 19,22 \\
\text { lipid }\end{array}$ & 7 & $\begin{array}{l}\leftrightarrow \text { FW, SGR, FCR, PER, \& NPU at } 13,16 \text { \& } 19 \% \text { lipid }+5 \% \\
\text { Ulva } \\
\uparrow \text { FW, SGR, \& PER at } 22 \% \text { lipid }+5 \% \text { Ulva } \\
\downarrow \text { FCR at } 22 \% \text { lipid }+5 \% \text { Ulva } \\
\leftrightarrow \text { NPU at } 22 \% \text { lipid }+5 \% \text { Ulva }\end{array}$ & $\begin{array}{l}\text { (Emre et al., } \\
2013)\end{array}$ \\
\hline Ulva rigida & $\begin{array}{l}\text { Rainbow } \\
\text { trout }\end{array}$ & C & 5,10 & $\begin{array}{c}12(+3 \\
\text { starvation })\end{array}$ & $\downarrow$ Weight loss after starvation & $\begin{array}{l}\text { (Güroy et al., } \\
\text { 2011) }\end{array}$ \\
\hline Ulva rigida & $\begin{array}{l}\text { European } \\
\text { seabass }\end{array}$ & C & 5,10 & 10 & $\begin{array}{l}\leftrightarrow \text { PER, VFI } \\
\downarrow \text { FW, Daily WG when \% inclusion } \uparrow \\
\uparrow \text { FCR when \% inclusion } \uparrow\end{array}$ & $\begin{array}{l}\text { (Valente et al. } \\
\text { 2006) }\end{array}$ \\
\hline Ulva rigida & $\begin{array}{l}\text { Gilthead } \\
\text { seabream }\end{array}$ & $\mathrm{O}$ & $5,15,25$ & 10 & $\begin{array}{l}\leftrightarrow \text { FW \& SGR at } 5 \& 15 \% \\
\leftrightarrow \text { CF \& FCR } \\
\uparrow F W \& \text { SGR at } 25 \%\end{array}$ & $\begin{array}{l}\text { (Vizcaíno et } \\
\text { al., 2015) }\end{array}$ \\
\hline Ulva rigida & Nile tilapia & $\mathrm{H}$ & $5,10,15$ & 12 & $\begin{array}{l}\downarrow \text { FW, WG, SGR, \& ANEU at } 15 \% \\
\uparrow \text { FCR, Dietary Protein \& Energy utilised at } 15 \% \\
\leftrightarrow \text { FI \& ANPU }\end{array}$ & $\begin{array}{l}\text { (Kut Guroy et } \\
\text { al., 2007) }\end{array}$ \\
\hline Ulva spp. & Nile tilapia & $\mathrm{H}$ & 10 & 12 & $\leftrightarrow \mathrm{FW}, \mathrm{SGR}, \mathrm{FI}, \mathrm{FCR}, \&$ PER & $\begin{array}{l}\text { (Silva et al., } \\
\text { 2014) }\end{array}$ \\
\hline $\begin{array}{l}\text { Ulva spp. }(1: 1, \\
\text { U. rigida:U. } \\
\text { lactuca }\end{array}$ & Nile tilapia & $\mathrm{H}$ & $10,15,20$ & 9 & $\begin{array}{l}\downarrow \text { FW, SGR at } 15 \& 20 \% \\
\uparrow \text { FCR when } \% \text { inclusion } \uparrow \\
\uparrow \text { PER at } 10 \& 15 \%, \\
\leftrightarrow \text { PER @ } 20 \%\end{array}$ & $\begin{array}{l}\text { (Marinho et } \\
\text { al., 2013)v }\end{array}$ \\
\hline Ulva pertusa & $\begin{array}{l}\text { Black } \\
\text { seabream }\end{array}$ & $\mathrm{O}$ & 10 & $\begin{array}{c}20.4(143 \\
\text { days })\end{array}$ & $\begin{array}{l}\leftrightarrow \text { Growth Rate, FE, } \\
\uparrow \text { PER } \\
\downarrow \text { FW, Growth Rate }\end{array}$ & $\begin{array}{l}\text { (Nakagawa et } \\
\text { al., 1984) }\end{array}$ \\
\hline
\end{tabular}




\begin{tabular}{|c|c|c|c|c|c|c|}
\hline Algae & Fish & $\begin{array}{c}\text { Natural } \\
\text { diet }\end{array}$ & $\begin{array}{c}\text { Inclusion } \\
(\%)\end{array}$ & $\begin{array}{l}\text { Duration } \\
\text { (weeks) }\end{array}$ & Growth effect & Reference \\
\hline \multicolumn{7}{|l|}{ Chlorophyta } \\
\hline $\begin{array}{l}\text { Ulva ohno } \\
\text { (derived meal) }\end{array}$ & $\begin{array}{l}\text { Atlantic } \\
\text { salmon }\end{array}$ & $\mathrm{C}$ & $2.5,5 \%$ & 12 & $\begin{array}{l}\leftrightarrow \mathrm{FW}, \mathrm{FI}, \mathrm{WG}, \mathrm{FCR}, \mathrm{SGR}, \mathrm{PER} \text {, protein growth rate, net } \\
\text { protein cultivation \& CF. }\end{array}$ & $\begin{array}{l}\text { (Norambuena } \\
\text { et al., 2015) }\end{array}$ \\
\hline $\begin{array}{l}\text { Ulva } \\
\text { (Enteromorpha) } \\
\text { prolifera }\end{array}$ & $\begin{array}{l}\text { Large } \\
\text { yellow } \\
\text { croaker }\end{array}$ & C & $5,10,15$ & 10 & $\begin{array}{l}\uparrow \mathrm{FW}, \text { when \% inclusion } \uparrow \\
\downarrow \text { Protein Retention when \% inclusion } \uparrow \\
\leftrightarrow \text { Feed Efficiency Ratio, Feeding Rate }\end{array}$ & $\begin{array}{l}\text { Asino et al. } \\
2011\end{array}$ \\
\hline \multicolumn{7}{|l|}{ Rhodophyta } \\
\hline $\begin{array}{l}\text { Eucheuma } \\
\text { denticulatum }\end{array}$ & $\begin{array}{l}\text { Asian } \\
\text { seabass }\end{array}$ & C & 5 & 8 & $\leftrightarrow \mathrm{FW}, \mathrm{WG}, \mathrm{SGR}$, Total FI, FCR, PER, NPU, \& CF & $\begin{array}{l}\text { (Shapawi and } \\
\text { Zamry, 2016) }\end{array}$ \\
\hline $\begin{array}{l}\text { Eucheuma } \\
\text { denticulatum }\end{array}$ & $\begin{array}{l}\text { Japanese } \\
\text { flounder }\end{array}$ & C & $3,6,9$ & 8 & $\begin{array}{l}\leftrightarrow \mathrm{FW}, W G, S G R, \& \text { PER at } 3 \% \\
\downarrow \mathrm{FW}, W G, S G R, \& \text { FER at } 6 \& 9 \% \\
\leftrightarrow \mathrm{FI}\end{array}$ & $\begin{array}{l}\text { (Ragaza et al., } \\
\text { 2013) }\end{array}$ \\
\hline $\begin{array}{l}\text { Gracilaria bursa- } \\
\text { pastoris }\end{array}$ & $\begin{array}{l}\text { European } \\
\text { seabass }\end{array}$ & C & 5,10 & 10 & $\leftrightarrow$ FW, Daily WG, FCR, PER, VFI & $\begin{array}{l}\text { (Valente et al., } \\
\text { 2006) }\end{array}$ \\
\hline $\begin{array}{l}\text { Gracilaria } \\
\text { cornea }\end{array}$ & $\begin{array}{l}\text { European } \\
\text { seabass }\end{array}$ & C & 5,10 & 10 & $\begin{array}{l}\leftrightarrow \text { PER \& VFI } \\
\downarrow \text { FW \&WG when \% inclusion } \uparrow \\
\uparrow \text { FCR when \% inclusion } \uparrow\end{array}$ & $\begin{array}{l}\text { (Valente et al., } \\
\text { 2006) }\end{array}$ \\
\hline $\begin{array}{l}\text { Gracilaria } \\
\text { cornea }\end{array}$ & $\begin{array}{l}\text { Gilthead } \\
\text { seabream }\end{array}$ & $\mathrm{O}$ & $5,15,25$ & 10 & $\begin{array}{l}\leftrightarrow \mathrm{FW}, \mathrm{SGR}, \mathrm{FCR}, \& \mathrm{CF} \text { at } 5 \& 15 \% \\
\leftrightarrow \mathrm{FW} \& \mathrm{CF} \text { at } 25 \% \\
\downarrow \mathrm{SGR} \text { at } 25 \% \\
\uparrow \mathrm{FCR} \text { at } 25 \%\end{array}$ & $\begin{array}{l}\text { (Vizcaíno et } \\
\text { al., 2015) }\end{array}$ \\
\hline $\begin{array}{l}\text { Gracilaria } \\
\text { lemaneiformis }\end{array}$ & $\begin{array}{l}\text { Black } \\
\text { seabream }\end{array}$ & $\mathrm{O}$ & $5,10,15$ & 8 & $\begin{array}{l}\leftrightarrow \mathrm{FW}, W G, \& \text { feed efficiency ratio at } 5,10,15 \\
\downarrow \mathrm{FW}, W G, \& \text { feed efficiency ratio at } 20 \%\end{array}$ & $\begin{array}{l}\text { (Xuan et al., } \\
\text { 2013) }\end{array}$ \\
\hline
\end{tabular}




\begin{tabular}{|c|c|c|c|c|c|c|}
\hline Algae & Fish & $\begin{array}{l}\text { Natural } \\
\text { diet }\end{array}$ & $\begin{array}{l}\text { Inclusion } \\
(\%)\end{array}$ & $\begin{array}{l}\text { Duration } \\
\text { (weeks) }\end{array}$ & Growth effect & Reference \\
\hline \multicolumn{7}{|l|}{ Rhodophyta } \\
\hline $\begin{array}{l}\text { Gracilaria } \\
\text { lemaneiformis }\end{array}$ & Rabbit fish & 0 & 33 & 8 & $\begin{array}{l}\downarrow F W, \text { WGR, SGR, PER } \\
\uparrow \text { FCR }\end{array}$ & $\begin{array}{l}\text { (Xu et al., } \\
2011)\end{array}$ \\
\hline $\begin{array}{l}\text { Gracilaria } \\
\text { vermiculophylla }\end{array}$ & Nile tilapia & $\mathrm{H}$ & 10 & 12 & $\begin{array}{l}\downarrow \mathrm{FW}, \mathrm{SGR}, \mathrm{FI}, \& \mathrm{PER} \\
\uparrow \mathrm{FCR}\end{array}$ & $\begin{array}{l}\text { (Silva et al., } \\
\text { 2014) }\end{array}$ \\
\hline $\begin{array}{l}\text { Gracilaria } \\
\text { vermiculophylla }\end{array}$ & $\begin{array}{l}\text { Rainbow } \\
\text { trout }\end{array}$ & C & 5,10 & 13 & $\begin{array}{l}\leftrightarrow \mathrm{FW}, \mathrm{SGR}, \mathrm{FCR}, \& \mathrm{VFI} \text { at } 5 \% \\
\downarrow \mathrm{FW}, \mathrm{SGR}, \& \mathrm{VFI} \text { at } 10 \% \\
\uparrow \mathrm{FCR} \text { at } 10 \%\end{array}$ & $\begin{array}{l}\text { (Valente et al., } \\
\text { 2015) }\end{array}$ \\
\hline $\begin{array}{l}\text { Gracilaria } \\
\text { vermiculophylla }\end{array}$ & $\begin{array}{l}\text { Rainbow } \\
\text { trout }\end{array}$ & C & 5,10 & 13 & $\begin{array}{l}\leftrightarrow \text { BL, Daily growth index, PER, \& FCR at } 5 \% \\
\downarrow \text { FW, BL, Daily growth index, \& PER at } 10 \% \\
\uparrow \text { FCR at } 10 \%\end{array}$ & $\begin{array}{l}\text { (Araújo et al., } \\
\text { 2015) }\end{array}$ \\
\hline $\begin{array}{l}\text { Gracilaria } \\
\text { pygmaea }\end{array}$ & $\begin{array}{l}\text { Rainbow } \\
\text { trout }\end{array}$ & C & $3,6,9,12$ & 7 & $\begin{array}{l}\uparrow \mathrm{FW} \text {, at } 6 \& 9 \% \\
\downarrow \text { SGR at } 12 \% \\
\downarrow \text { FCR at } 3,6 \text { \& } 9 \% \\
\uparrow \mathrm{FI} \text { as } \uparrow \text { inclusion } \% \text { level }\end{array}$ & $\begin{array}{l}\text { Sotoudeh \& } \\
\text { Jafari, } 2017\end{array}$ \\
\hline $\begin{array}{l}\text { Kappaphycus } \\
\text { alvarezii }\end{array}$ & $\begin{array}{l}\text { Asian } \\
\text { seabass }\end{array}$ & C & 5 & 8 & $\leftrightarrow$ FW, WG, SGR, Total FI, FCR, PER, NPU, \& CF. & $\begin{array}{l}\text { (Shapawi and } \\
\text { Zamry, 2016) }\end{array}$ \\
\hline $\begin{array}{l}\text { Kappaphycus } \\
\text { alvarezii }\end{array}$ & $\begin{array}{l}\text { Asian } \\
\text { seabass }\end{array}$ & $\mathrm{C}$ & $\begin{array}{l}6 \text { (raw) \& } 6 \\
10,14,18 \\
22(\text { cooked })\end{array}$ & 10 & $\begin{array}{l}\leftrightarrow \text { FW, WG, SGR, Total FI, Daily FI, FCR, PER, NPU. \& CF } \\
\text { at } 6 \% \text { Raw } \\
\uparrow \mathrm{FW}, \text { WG, SGR, PER, NPU. \& CF, \& } \downarrow \text { FCR at } 6 \% \text { cooked } \\
\downarrow \text { FW, WG, SGR, PER, NPU. \& CF, \& } \uparrow \text { FCR at } \% \text { cooked } \uparrow \\
\text { (generally) }\end{array}$ & $\begin{array}{l}\text { (Shapawi et } \\
\text { al., 2015) }\end{array}$ \\
\hline $\begin{array}{l}\text { Palmaria } \\
\text { Palmata }\end{array}$ & $\begin{array}{l}\text { Atlantic } \\
\text { salmon }\end{array}$ & C & $5,10,15$ & 14 & $\leftrightarrow \mathrm{FW}, \mathrm{WG}, \mathrm{CF}, \mathrm{FCR}, \& \mathrm{SGR}$ & $\begin{array}{l}\text { (Wan et al., } \\
2016)\end{array}$ \\
\hline
\end{tabular}




\begin{tabular}{|c|c|c|c|c|c|c|}
\hline Algae & Fish & $\begin{array}{c}\text { Natural } \\
\text { diet }\end{array}$ & $\begin{array}{c}\text { Inclusion } \\
(\%)\end{array}$ & $\begin{array}{c}\text { Duration } \\
\text { (weeks) }\end{array}$ & Growth effect & Reference \\
\hline \multicolumn{7}{|l|}{ Rhodophyta } \\
\hline Porphyra dioica & $\begin{array}{l}\text { Rainbow } \\
\text { trout }\end{array}$ & $\mathrm{C}$ & $5,10,15$ & 12.5 & $\begin{array}{l}\uparrow F W \text { at } 15 \% \\
\leftrightarrow \text { WG, SGR, FCR, FE, PER, Protein Retention Efficiency, } \\
\& \text { VFI. }\end{array}$ & $\begin{array}{l}\text { (Soler-Vila et } \\
\text { al., 2009) }\end{array}$ \\
\hline $\begin{array}{l}\text { Porphyra } \\
\text { purpurea }\end{array}$ & Grey mullet & $\mathrm{O}$ & $16.5,33$ & 10 & $\begin{array}{l}\downarrow F W, W G, S G R, \text { Daily FI, FE, PER, \& Net Protein } \\
\text { Utilisation when \% inclusion } \uparrow \\
\uparrow \text { FCR when } \% \text { inclusion } \uparrow\end{array}$ & $\begin{array}{l}\text { (Davies et al., } \\
\text { 1997) }\end{array}$ \\
\hline Porphyra spp. & Atlantic cod & $\mathrm{O}$ & $5.5,11$ & 12 & $\leftrightarrow \mathrm{FW}, \mathrm{FI}$, Percentage growth, SGR, \& FCR. & $\begin{array}{l}\text { (Walker et al., } \\
\text { 2009) }\end{array}$ \\
\hline $\begin{array}{l}\text { Pterocladia } \\
\text { capillacea }\end{array}$ & $\begin{array}{l}\text { European } \\
\text { seabass } \\
\text { (fry) }\end{array}$ & C & $5,10,15$ & 8 & $\begin{array}{l}\uparrow F W, W G \text { at } 5 \% \\
\downarrow F W, W G \text { at } 10 \& 15 \% \\
\uparrow F C R \text { at } 15 \% \\
\downarrow P E R \text { at } 10 \& 15 \% \\
\downarrow P P V \text { at } 15 \%\end{array}$ & $\begin{array}{l}\text { (Wassef et al., } \\
\text { 2013) }\end{array}$ \\
\hline $\begin{array}{l}\text { Pyropia } \\
\text { (Porphyra) } \\
\text { yezoensis } \\
\text { (spheroplasts) }\end{array}$ & $\begin{array}{l}\text { Red } \\
\text { seabream }\end{array}$ & C & 5 & 6 & $\begin{array}{l}\uparrow F W, \text { WG, \% Growth, SGR, PRR, LRR, \& PER } \\
\downarrow \text { FCR }\end{array}$ & $\begin{array}{l}\text { (Kalla et al., } \\
2008 \text { ) }\end{array}$ \\
\hline $\begin{array}{l}\text { Pyropia } \\
\text { (Porphyra) } \\
\text { yezoensis Ueda }\end{array}$ & Nile tilapia & $\mathrm{H}$ & 15,30 & 10 & $\uparrow \mathrm{FW}, \mathrm{WG}, \mathrm{SGR}, \mathrm{FI}, \mathrm{PER}, \mathrm{PPV}, \&$ ALC at $15 \%$ & $\begin{array}{l}\text { (Stadtlander et } \\
\text { al., 2013) }\end{array}$ \\
\hline $\begin{array}{l}\text { Pyropia } \\
\text { yezoensis } \\
\text { (autoclave } \\
\text { extract) }\end{array}$ & $\begin{array}{l}\text { Olive } \\
\text { flounder }\end{array}$ & $\mathrm{C}$ & $\begin{array}{c}0.5,1,1.5 \\
2\end{array}$ & 9 & $\begin{array}{l}\leftrightarrow \text { FW, WG, Daily growth rate, \& Daily FI at } 5,10,15 \% \\
\leftrightarrow \text { feed efficiency at } 5 \& 10 \% \\
\uparrow \text { feed efficiency at } 15 \% \\
\leftrightarrow \text { FW \& Daily FI at } 20 \% \\
\downarrow \text { WG, daily growth rate, \& feed efficiency at } 20 \%\end{array}$ & $\begin{array}{l}\text { (Choi et al., } \\
2015 \text { ) }\end{array}$ \\
\hline
\end{tabular}




\begin{tabular}{|c|c|c|c|c|c|c|}
\hline $\begin{array}{l}\text { Ascophyllum } \\
\text { nodosum }\end{array}$ & $\begin{array}{l}\text { Red } \\
\text { seabream }\end{array}$ & C & $2.5,5$ & $\begin{array}{l}7.1(50 \\
\text { days })\end{array}$ & $\begin{array}{l}\downarrow \text { WG, Feed Conservation Efficiency, } \\
\downarrow \text { PER \& BL at } 2.5 \% \\
\uparrow \mathrm{BL} \& \mathrm{FW} \text { at } 5 \%\end{array}$ & $\begin{array}{l}\text { (Nakagawa, } \\
1997 \text { ) }\end{array}$ \\
\hline Algae & Fish & $\begin{array}{l}\text { Dietary } \\
\text { group }\end{array}$ & $\begin{array}{l}\text { Inclusion } \\
(\%)\end{array}$ & $\begin{array}{l}\text { Duration } \\
\text { (weeks) }\end{array}$ & Growth effect & Reference \\
\hline \multicolumn{7}{|l|}{ Phaeophyceae } \\
\hline $\begin{array}{l}\text { Ascophyllum } \\
\text { nodosum }\end{array}$ & $\begin{array}{l}\text { Red } \\
\text { seabream }\end{array}$ & C & 5,10 & 10 & $\begin{array}{l}\downarrow \mathrm{FW} \text { at } 10 \% \\
\downarrow \mathrm{FE} \text { at } 10 \% \\
\uparrow \mathrm{FE} \text { at } 5 \%\end{array}$ & $\begin{array}{l}\text { (Yone et al., } \\
\text { 1986) }\end{array}$ \\
\hline $\begin{array}{l}\text { Cystoseira } \\
\text { barbata }\end{array}$ & Nile tilapia & $\mathrm{H}$ & $5,10,15$ & 12 & $\begin{array}{l}\uparrow \text { Dietary Protein \& Energy utilisation at } 15 \% \\
\leftrightarrow \text { FW, WG, SGR, ANEU, \& FCR }\end{array}$ & $\begin{array}{l}\text { (Kut Guroy et } \\
\text { al., 2007) }\end{array}$ \\
\hline Ecklonia cava & $\begin{array}{l}\text { Olive } \\
\text { flounder }\end{array}$ & C & 6 & 6 & $\leftrightarrow \mathrm{FW}, \mathrm{WG}, \mathrm{FCR}, \mathrm{PER}, \mathrm{FI}, \& \mathrm{CF}$ & $\begin{array}{l}\text { (Kim et al., } \\
2014)\end{array}$ \\
\hline $\begin{array}{l}\text { Macrocystis } \\
\text { pyrifera }\end{array}$ & $\begin{array}{l}\text { Rainbow } \\
\text { trout }\end{array}$ & $\mathrm{C}$ & $1.5,3,6$ & $\begin{array}{c}17.7 \\
(124 \text { days })\end{array}$ & $\begin{array}{l}\downarrow \text { FW \& SGR when } \% \uparrow \\
\leftrightarrow \text { FCR }\end{array}$ & $\begin{array}{l}\text { (Dantagnan et } \\
\text { al., 2009) }\end{array}$ \\
\hline $\begin{array}{l}\text { Sargassum } \\
\text { polycystum }\end{array}$ & $\begin{array}{l}\text { Asian } \\
\text { seabass }\end{array}$ & $\mathrm{C}$ & 5 & 8 & $\begin{array}{l}\leftrightarrow \text { FW, WG, SGR, FCR, PER, NPU, \& CF } \\
\uparrow \mathrm{FI}\end{array}$ & $\begin{array}{l}\text { (Shapawi and } \\
\text { Zamry, 2016) }\end{array}$ \\
\hline $\begin{array}{l}\text { Sargassum } \\
\text { fusiforme }\end{array}$ & $\begin{array}{l}\text { Olive } \\
\text { flounder }\end{array}$ & $\mathrm{C}$ & 6 & 6 & $\leftrightarrow \mathrm{FW}, \mathrm{WG}, \mathrm{FCR}, \mathrm{PER}, \mathrm{FI}, \& \mathrm{CF}$ & $\begin{array}{l}\text { (Kim et al., } \\
2014)\end{array}$ \\
\hline $\begin{array}{l}\text { Undaria } \\
\text { penatifida }\end{array}$ & $\begin{array}{l}\text { Red } \\
\text { seabeam }\end{array}$ & $\mathrm{C}$ & 5,10 & 10 & $\begin{array}{l}\uparrow \mathrm{FW} \text { at } 5 \% \\
\uparrow \mathrm{FE}\end{array}$ & $\begin{array}{l}\text { (Yone et al., } \\
1986)\end{array}$ \\
\hline
\end{tabular}

$\uparrow$ - increase; $\leftrightarrow$ no change, $\downarrow$ decrease compared to the control diet $(p<0.05)$. Carnivore- C; Omnivore- O; Herbivore- H; Detritivore- D. Apparent Net Energy Utilisation-ANEU; Apparent Net Protein Utilisation- ANPU; Body length- BL; Condition Factor- CF; Feed Conversion Ratio- FCR; Feed Efficiency- FE; 
Feed Intake-FI; Specific Growth Rate-SGR; Final Weight- FW; Protein Efficiency Ratio-PER; Weight Gain- WG; Voluntary Feed Intake-VFI. ${ }^{\mathrm{a}} \mathrm{www}$.fishbase.org 
1 Table 4: Economical analysis of the use of Ulva spp. blooms as a feed component in Atlantic

2 salmon (Salmo salar) diet.

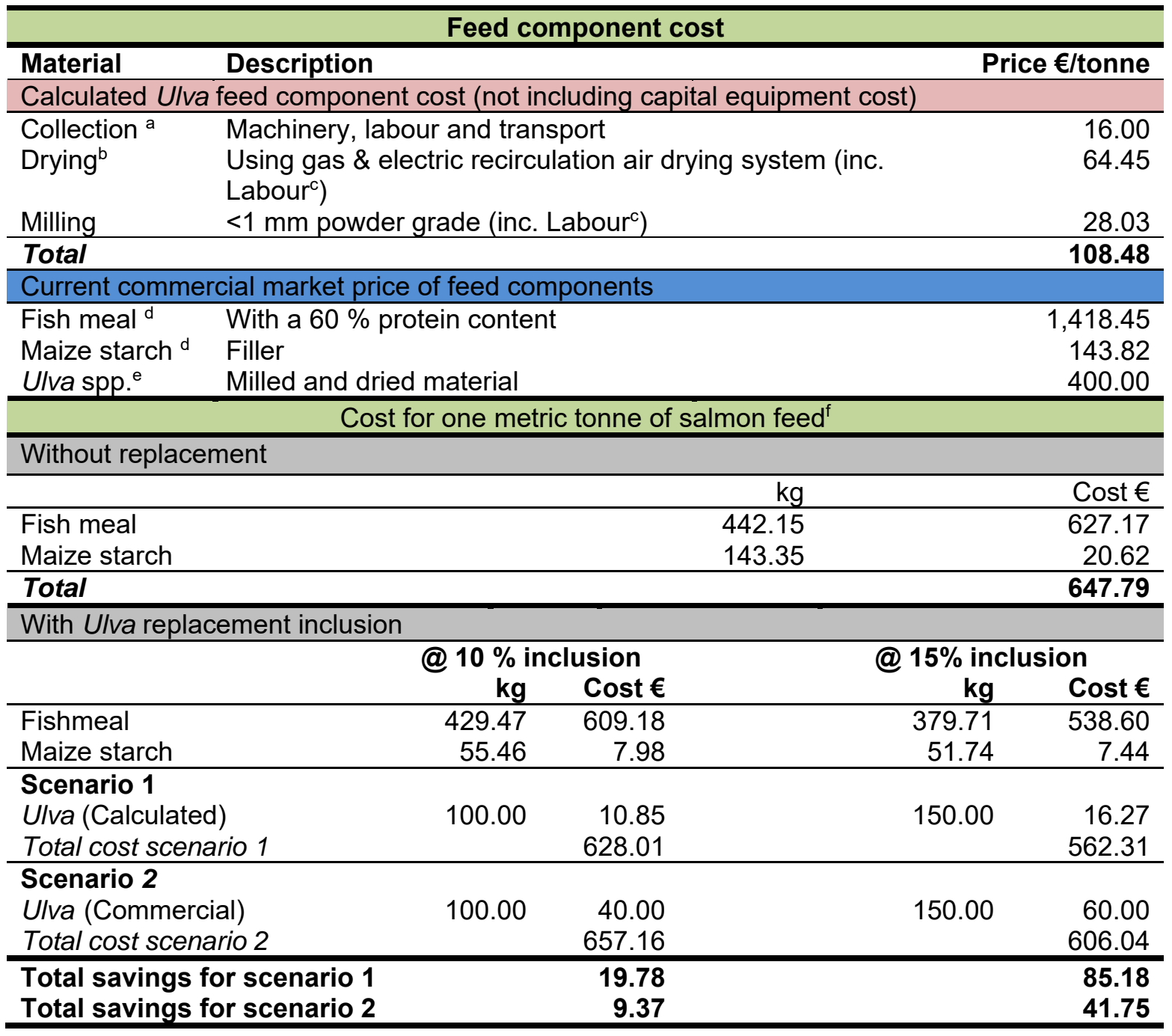

$7 \quad{ }^{\text {b }}$ Calculation performed on lowa State University grain cost calculator, suing the following

8 assumptions:

9 Moisture content: Initial- $79.6 \%$ (Marsham et al., 2007) and final $9 \%$

10 Drying capacity: 15.86 tonne $\mathrm{hr}^{-1}$

11 Propane gas cost: €0.38 litre

12 Electricity cost: $€ 0.11 \mathrm{Kwh}^{-1}$

13 www.extension.iastate.edu/agdm/crops/xls/a1-20dryingcostcalculator.xls

14 'Labour rate $€ 25.00$ hour $^{-1}$

15 dMean price from Jan-Dec 2016, data from Worldbank.org through Indexmundi.com

$16 \mathrm{http} / /$ www.indexmundi.com/commodities/?commodity=fish-meal

17 http://www.indexmundi.com/commodities/?commodity=corn\&months=12\&currency=eur

18 e Accessed on 14-06-17, Alibaba.com

$19{ }^{\mathrm{f}}$ Basal salmon feed formulation; $40 \%$ protein, $25 \%$ lipid; energy $25 \mathrm{MJ} \mathrm{kg}^{-1}$ 
Figure 1: A roadmap to the future potential of macroalgae in fish nutrition.

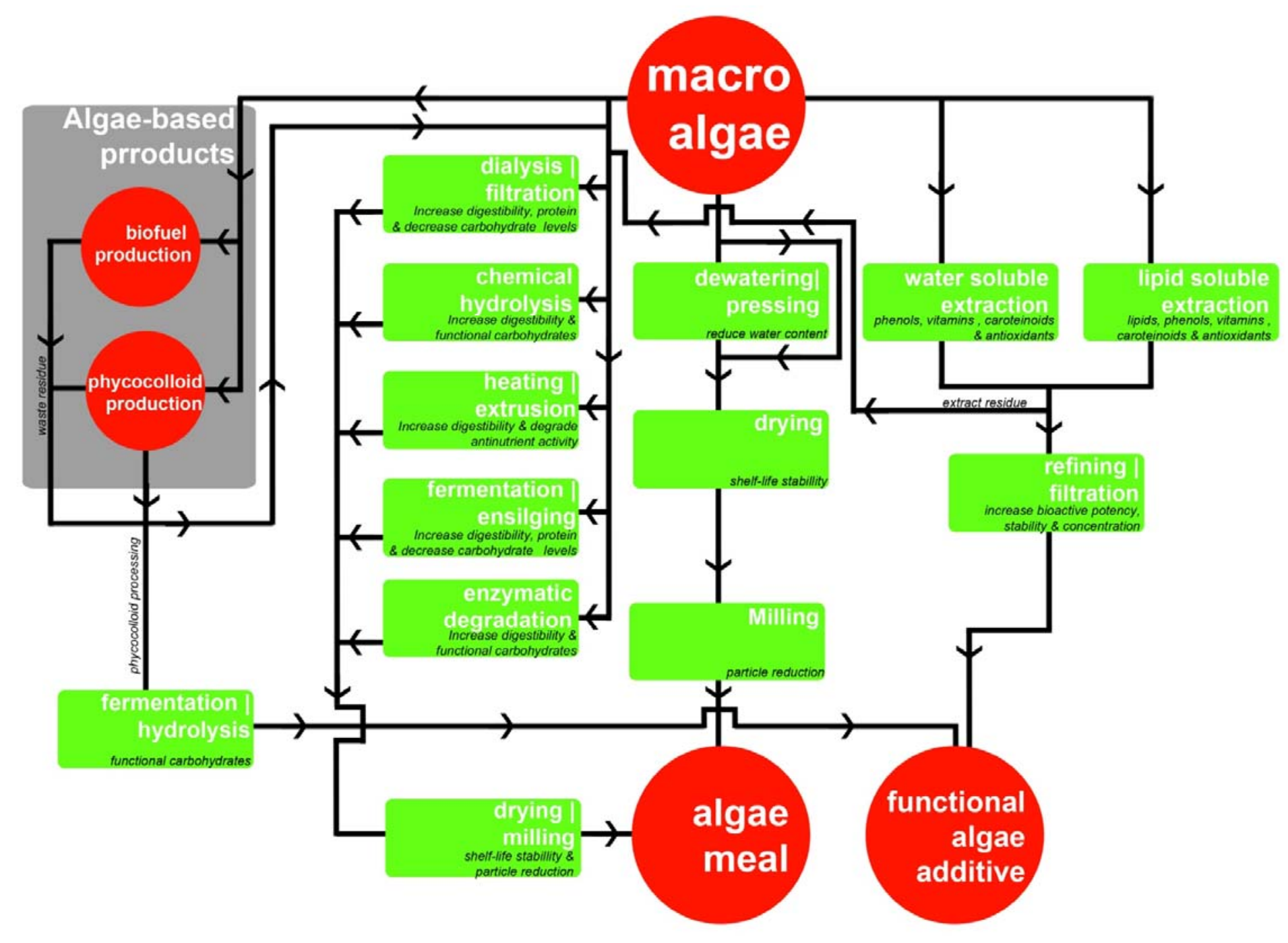

